Universidade de São Paulo

Escola Superior de Agricultura "Luiz de Queiroz"

\title{
Bases genéticas e fisiológicas da capacidade de regeneração in vitro apresentada por espécies selvagens relacionadas ao tomateiro (Solanum lycopersicum L.)
}

Fernanda Namie Arikita

Dissertação apresentada para obtenção do título de Mestre em Ciências. Área de concentração: Fisiologia e Bioquímica de Plantas

Piracicaba

2011 


\section{Fernanda Namie Arikita \\ Engenheiro Agrônomo}

Bases genéticas e fisiológicas da capacidade de regeneração in vitro apresentada por espécies selvagens relacionadas ao tomateiro (Solanum lycopersicum L.)

Orientador:

Prof. Dr. LÁZARO EUSTÁQUIO PEREIRA PERES

Dissertação apresentada para obtenção do título de Mestre em Ciências: Área de concentração: Fisiologia e Bioquímica de Plantas

Piracicaba

2011 


\section{Dados Internacionais de Catalogação na Publicação}

DIVISÃO DE BIBLIOTECA - ESALQ/USP

\section{Arikita, Fernanda Namie}

Bases genéticas e fisiológicas da capacidade de regeneração in vitro apresentada por espécies selvagens relacionadas ao tomateiro (Solanum lycopersicum L.) / Fernanda Namie Arikita. - - Piracicaba, 2011.

99 p. : il.

Dissertação (Mestrado) - - Escola Superior de Agricultura "Luiz de Queiroz", 2011.

1. Genética fisiológica 2. Genética molecular vegetal 3. Genes 4. Hibridação vegetal 5. Regeneração 6. Tomate I. Título

CDD 635.642

A699b

\section{"Permitida a cópia total ou parcial deste documento, desde que citada a fonte - 0 autor"}



Dedico este trabalho aos meus pais e minhas irmãs, pelo incentivo, paciência e colaboração, em todos os momentos desta e de outras caminhadas 


\section{AGRADECIMENTOS}

Primeiramente aos meus pais, Airton e Terumi, pois formaram os fundamentos do meu caráter e me apontaram a vida. Obrigada por serem a minha referência de tantas maneiras e estarem sempre presentes na minha vida de uma forma indispensável, mesmo separados por tantos quilômetros.

Ao meu professor e orientador deste trabalho, Lázaro, pelo desprendimento ao escolher me dar apoio, pelo auxílio, ajuda e conversas durante a elaboração dos experimentos até a fase final "messsssssmo".

A Cássia nossa "mãezona" do laboratório, pelas conversas, ajudas, pelo "mutirão" das sextas-feiras e companhia.

A amigona Eloísa pelos almoços, pelas idas à CV (pela chuva) e pela companhia.

A Mariana por ter me ajudado muito no laboratório, nos experimentos e pela paciência e auxílio na elaboração da minha dissertação. Boa sorte em São Paulo.

Ao Frederico (Fred) pela ajuda com os artigos e "saunas" na CV.

Ao Ivan pelas dicas e correções com a minha dissertação.

Aos ICs Gabriel e Guilherme pelas conversas, risadas e cafés.

Aos novatos: Mateus e João Pedro, pelas histórias de Mineiros, a mítica Guapé.

Ao Viti pela ajuda na casa de vegetação (CV).

A Solizete pela eficiência, super ajuda em tudo e compreensão. 
Enfim Galerinha do Laboratório de Controle Hormonal do Desenvolvimento Vegetal esse é só o começo de uma grande história. Boa sorte para todos !!!

\section{MUITO OBRIGADA}




\section{SUMÁRIO}

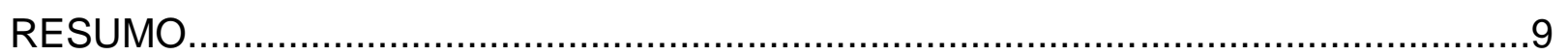

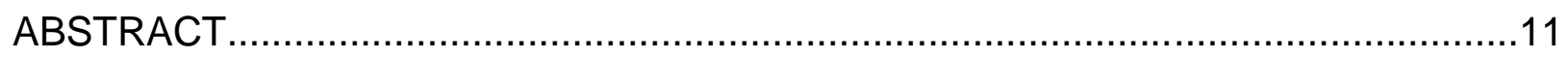

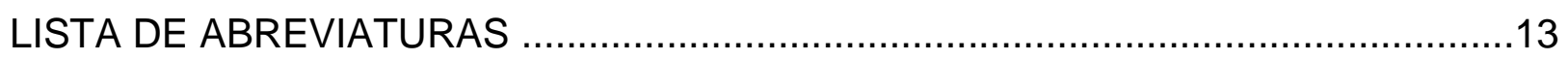

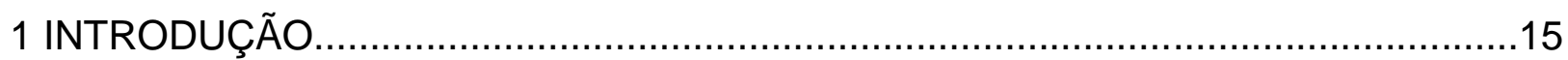

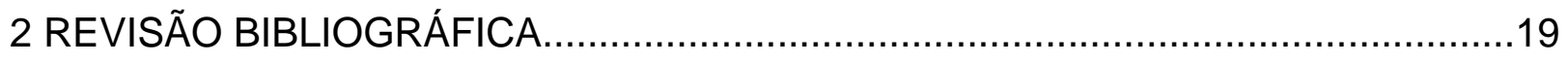

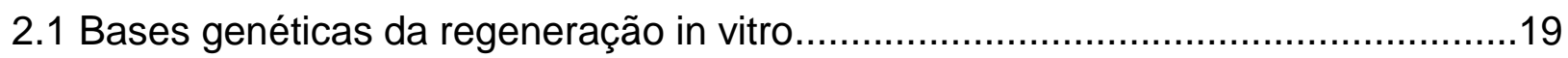

2.2 Tomateiro como modelo para o estudo genético da regeneração in vitro...............20

2.3 Ferramentas genéticas disponíveis em tomateiro ............................................21

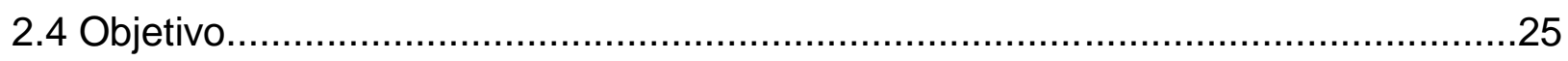

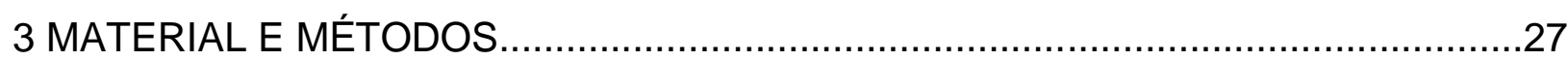

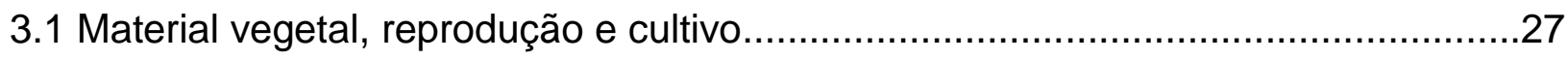

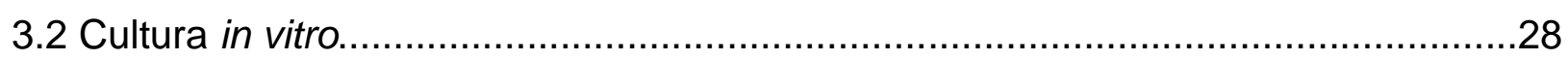

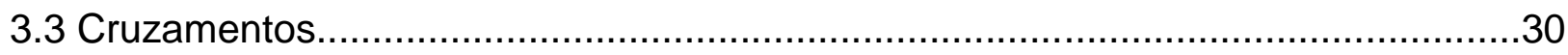

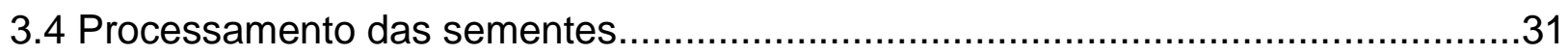

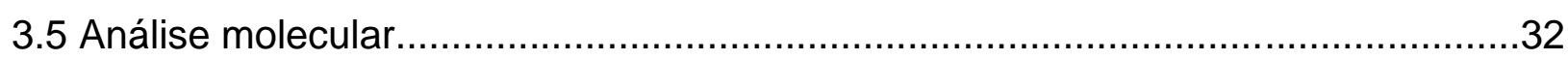

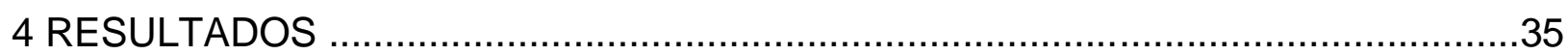

4.1 Análise do efeito dos alelos selvagens: Self pruning (Sp), Dwarf (D) e Uniform

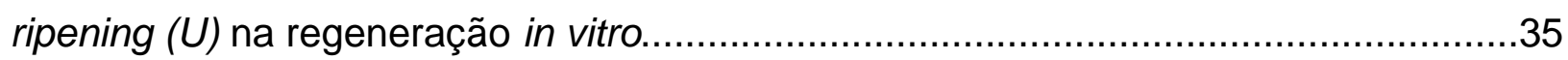

4.2 Seleção das ILs quanto a capacidade de regeneração........................................38

4.3 Verificação da capacidade das ILs para a formação de raízes...............................43

4.4 Retocruzametos das ILs selecionadas com a planta modelo MT e análise

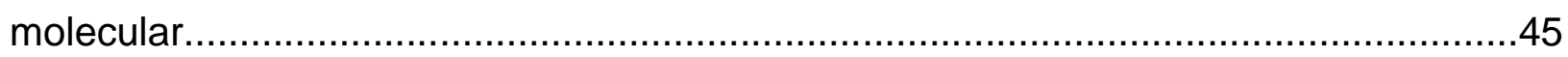

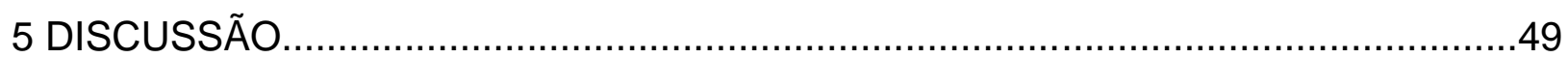

5.1 As possíveis funções dos genes para os locos de controle da organogênese in vitro......

5.2 Implicações para a evolução e domesticação do tomateiro...................................53

5.3 Implicações para a biotecnologia e melhoramento do tomateiro..............................55

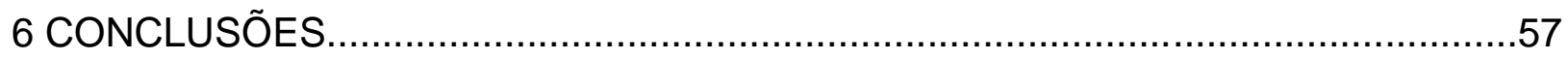

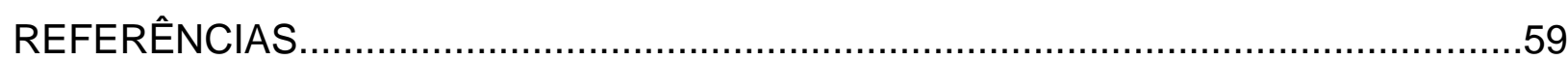




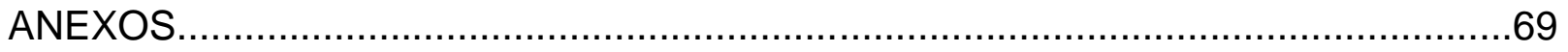




\title{
RESUMO
}

\section{Bases genéticas e fisiológicas da capacidade de regeneração in vitro apresentada por espécies selvagens relacionadas ao tomateiro (Solanum lycopersicum L.)}

\begin{abstract}
O tomateiro (Solanum lycopersicum L.) é um interessante modelo para estudar a base genética da capacidade de formação de órgãos adventícios, uma vez que existem variações genéticas naturais consideráveis em seus parentes selvagens. Assim, sabese que o alelo dominante $R g 1$, presente no braço curto do cromossomo 3 de $S$. peruvianum, confere alta capacidade de regeneração de gemas caulinares. Usando uma coleção de 50 linhas de introgressão (ILs), cada uma contendo um pequeno segmento cromossômico de $S$. pennellii LA716 introgredido e mapeado na cultivar M82, foram realizados testes com explantes cotiledonares com 12 dias de idade cultivados em meio MS contendo 5,0 $\mu \mathrm{M}$ BAP, e encontramos uma alta capacidade de regeneração de gemas caulinares nas IL3-2, IL6-1, IL7-1, IL 8-3, IL-9-1 e IL10-2. Isto significa que $S$. pennellii provavelmente possua alelos com capacidade superior para a regeneração in vitro nessas regiões cromossômicas, incluindo um possível novo alelo para Rg1 na IL3-2. Plântulas em F1 do cruzamento entre Micro-Tom x ILs e ILs x ILs provaram que a capacidade de regeneração de gemas caulinares foi dominante nas ILs 3-2, 6-1, 7-1 e 8-3, e que a capacidade de regeneração das IL8-3 aumentou a das outras ILs, comportando-se de uma maneira aditiva. Uma vez que as ILs 3-2, 7-1, 8-3 e 10-2 também aumentaram a formação de raízes em meio MS contendo 0,4 $\mu \mathrm{M}$ ANA, elas podem apresentar novos alelos que controlam a fase de competência, estando aptas a assumir diferentes destinos celulares, ao invés da indução de um órgão específico. Também realizamos a introgressão dos alelos selecionados para o modelo genético Micro-Tom, o qual proporcionará a caracterização e isolamento de genes importantes para estudos de desenvolvimento de plantas e aplicações biotecnológicas.
\end{abstract}

Palavras-chave: Linhas de introgressão; Micro-Tom; Regeneração; RG1; Alelos 


\section{ABSTRACT \\ Genetic and physiological basis of the in vitro regeneration capacity presented by tomato (Solanum lycopersicum L.) wild related species}

Tomato (Solanum lycopersicum L.) is an attractive model to study the genetic basis of adventitious organ formation capacity, since there is considerable natural genetic variation in its wild relatives. Accordingly, it is known that the dominant $R g 1$ allele, present in the short arm of $S$. peruvianum chromosome 3 , confers high shoot regeneration capacity. Using a set of 50 introgression lines (ILs), each containing small a chromosomal segment of $S$. pennellii LA716 introgressed and mapped into the tomato cultivar M82, we found a high shoot regeneration capacity for IL3-2, IL6-1, IL7-1, IL 8-3, IL-9-1 and IL10-2, when 12-days-old cotyledon explants were cultivated in MS medium containing 5.0 $\mu \mathrm{M}$ BAP, suggesting that. S. pennellii might present superior alleles for in vitro regeneration in such chromosomal regions, including a possible novel allele for Rg1 in IL3-2. F1 seedlings from the crosses Micro-Tom $\times$ ILs and ILs $\times$ ILs demonstrated that the shoot regeneration capacity of the ILs 3-2, 6-1, 7-1 and 8-3 was dominant and that the regeneration ability of IL8-3 enhanced that of the other ILs in an additive manner. Since ILs 3-2, 7-1, 8-3, and 10-2 also exhibited enhanced root formation on MS medium containing $0.4 \mu \mathrm{M}$ NAA, these segments might contain novel alleles controlling the competence to assume distinct cell fates, rather than the induction of a specific organ. We also performed the introgression of such alleles into the genetic model system Micro-Tom, which will enable the characterization and isolation of important genes for plant development studies and biotechnological applications.

Keywords: Introgression lines; Micro-Tom; Regeneration; Rg1; Alleles 


\section{LISTA DE ABREVIATURAS}
ANA = Ácido $\alpha$-naftalenoacético
$\mathrm{BAP}=6$-belzilaminopurina
ILs = Linhas de introgressão
MS = Murashige e Skoog
MT = Micro-Tom
NILs = Linhas quase isogênicas
QTL = Locos de características quantitativas
$\mathrm{U}=$ unidade 


\section{INTRODUÇÃO}

Apesar da ampla utilização da regeneração de plantas em aplicações biotecnológicas (VASIL, 2008), a base genética dessa capacidade permanece em grande parte desconhecida. Há muito tempo sabe-se que a organogênese vegetal pode ser controlada pelas proporções relativas entre os hormônios auxina e citocinina (SKOOG; MILLER, 1957). Isto implica que qualquer variação genética que altere os níveis destes dois hormônios, ou a resposta a eles, provavelmente influenciará a capacidade de formação de órgãos adventícios. Assim, é concebível que algumas plantas que produzem citocininas em elevadas quantidades são propensas a formar gemas caulinares in vitro (PERES; KERBAUY, 1999; ESTRUCH et al., 1991; CATTEROU et al., 2002), assim como tem sido relatado que plantas transgênicas com maior sensibilidade a auxina costumam produzir excesso de raízes (PERES et al., 2001; LIMA et al., 2009). Além disso, foi demonstrado em Arabidopsis que a expressão de genes que controlam a resposta a citocinina ou a idendentidade do meristema caulinar correlaciona-se com a indução de gemas caulinares adventícias (CARY et al., 2002;. GALLOIS et al., 2002;. CHE et al., 2006, 2007). No entanto, há uma falta de informação que relacione esses tipos de genes com a variação observada na capacidade de formação de órgãos adventícios entre as plantas cultivadas e seus parentes selvagens (MATHIAS; FUKUI, 1986; BOHOROVA et al., 1986;. HU et al., 1999;. KOORNNEEF et al., 1997; PERES et al., 2001).

Estudos genéticos e fisiológicos são aprimorados através do uso de plantas modelos onde mutantes e variações alélicas naturais estão disponíveis (KOORNNEEF et al., 1997). O tomateiro (Solanum lycopersicum L.) possui várias características que o tornam um excelente modelo genético: é uma espécie diplóide autógama com um genoma relativamente pequeno (950 Mb), sendo seus genes distribuído em 12 cromossomos e facilmente mapeados devido a uma abundância de marcadores (http://solgenomics.net/) associados a características de importância econômica e biológica. Além disso, o tomateiro apresenta um grande número de mutantes bem caracterizados (http://tgrc.ucdavis.edu/). Além das mutações induzidas, a variação genética natural (ALONSO-BLANCO; KOORNNEEF, 2000) é um recurso valioso para a 
genética. Essas variações podem ser encontradas no gênero Solanum seção Lycopersicum o qual possui nove espécies selvagens que, com maior ou menor dificuldade, podem ser cruzadas com o tomateiro cultivado (STEVENS; RICK, 1986). Estas espécies são fontes valiosas de locos de características quantitativas (QTL) e também de variação alélica para genes de comportamento mendeliano (BAl; LINDHOUT, 2007). A observação de novos fenótipos oriundos das espécies selvagens, e os genes por trás deles, é facilitada pela utilização das linhas de introgressão (ILs), que são populações permanentes (ESHED; ZAMIR, 1994). Uma vez identificado, o efeito específico de uma determinada variação genética natural pode ser eficientemente estudado pela construção das linhas quase isogênicas (NILs), as quais diferem apenas em uma única região de QTL ou gene mendeliano (PARAN; ZAMIR, 2003). A cultivar de tomateiro Micro-Tom (MEISSNER et al., 1997) é uma planta de porte pequeno e de ciclo curto que pode acelerar a criação de NILs, uma vez que este processo leva pelo menos seis gerações de retrocruzamentos (CARVALHO et al., 2011). O tomateiro Micro-Tom (MT) é uma planta anã de crescimento determinado, originalmente criado para fins ornamentais (SCOTT; HARBAUGH, 1989), e posteriormente proposta por Meissner et al. (1997) como modelo genético.

O tomateiro tem provado ser um excelente modelo para o estudo das variações genéticas naturais que controlam a capacidade de regeneração in vitro. Entre as espécies selvagens relacionadas ao tomateiro, $S$. peruvianum e seu irmão $S$. chilense são considerados altamente organogênicos (NORTON; BOLL, 1954; KUT; EVANS, 1982;. PERES et al., 2001). Já foi relatada também a ocorrência de genótipos de $S$. habrochaites que variam desde recalcitrantes (KUT; EVANS, 1982; STOMMEL; SINDEN, 1991) até altamente organogênicos (STOMMEL; SINDEN, 1991; PERES et al., 2001). Outros genótipos que já descritos pela sua capacidade de formar gemas caulinares in vitro foram: S. pimpinellifolium WV700 (de FARIA et al., 2002.) e as cultivares UC82B (HAMZA; CHUPEAU, 1993), VFNT Cherry (MEREDITH, 1979) e Lukullus (MORGAN; COCKING, 1982). No entanto, a base genética de tal capacidade somente foi sugerida para S. pimpinellifolium WV700 (de FARIA et al., 2002). Estudando a base genética da capacidade organogênica em $S$. peruvianum, Koornneef et al. (1987) demonstraram que essa característica estava associada a dois alelos 
dominantes principais, nomeados $R g 1$ e $R g$ 2. Porém, apenas o alelo $R g 1$ é suficiente para iniciar o processo de formação de gemas caulinares a partir de explantes radiculares, sendo este mapeado no cromossomo 3, próximo ao loco yellow flesh $(r)$ (KOORNNEEF et al., 1993). O alelo recessivo $r$ representa uma perda de função no gene fitoeno sintase específico do cromoplasto (FRAY; GRIERSON, 1993), que confere cor amarela aos frutos, quando introgredido em $S$. lycopersicum. Foi sugerido que outras espécies de frutos verdes que abrigam o alelo $r$ também poderiam apresentar versões do alelo $R g 1$ conferindo alta capacidade organogênica (PERES et al., 2001). A presença do alelo $r$ nas espécie de frutos verdes, como em $S$. peruvianum, gerou a oportunidade de usá-lo como um marcador morfológico para a introgressão de $R g 1$ no tomateiro cultivado. Usando este procedimento, o alelo $R g 1$ de $S$. peruvianum foi transferido para a cv MT (LIMA et al., 2004) e está sendo apresentada como um instrumento de transformação genética desta planta modelo (PINO et al., 2010), podendo essa abordagem se estender a outras cultivares de tomateiro. Isso aponta para a importância da biotecnologia para descobrir novos alelos capazes de controlar a capacidade de regeneração in vitro do tomateiro. Além disso, uma vez que estudos anteriores sugerem que outros locos podem controlar essa característica (KOORNNEEF et al., 1987; de FARIA et al., 2002), a sua identificação e mapeamento será favorável para desvendar a via de transdução de sinal desse importante processo de desenvolvimento.

No presente trabalho, estamos relatando a alta capacidade de regeneração in vitro da espécie de frutos verdes $S$. pennellii LA716, o que nos permitiu utilizar uma coleção de 50 ILs, cada uma contendo um pequeno segmento cromossômico de $S$. pennellii LA716 introgredido e mapeado na cultivar M82, para procurar variações genéticas naturais que controlam a capacidade de formação de órgãos in vitro. Descobrimos alelos com superior capacidade de regeneração em $S$. pennellii presente em pelo menos seis ILs, incluindo a IL3-2, que corresponde aos locos $R g 1$ e $r$. A alta regeneração apresentadas por algumas ILs provou ser dominante e apresentando efeito aditivo quando combinadas umas com as outras. Quatro das seis ILs selecionadas aumentaram a capacidade de formação tanto de caules quanto de raízes nos meios adequados, o que pode indicar que eles representam novos alelos capazes 
de controlar a competência para assumir destinos celulares diferentes, ao invés da indução de um órgão específico. Também realizamos a introgressão dos alelos selecionados no modelo genético Micro-Tom, o qual favorecerá a posterior caracterização e isolamento de genes importantes para estudos de desenvolvimento vegetal e aplicações biotecnológicas. 


\section{REVISÃO BIBLIOGRÁFICA}

\subsection{Bases genéticas da regeneração in vitro}

A regeneração in vitro de plantas, envolvendo a embriogênese somática e a organogênese adventícia, proporcionaram modelos úteis para estudos fisiológicos, bioquímicos e moleculares sobre o desenvolvimento de plantas (SUGIYAMA, 2000). O processo de organogênese é dividido em diferentes fases: desdiferenciação, aquisição de competência, indução, determinação e diferencição. A não obtenção da regeneração de plantas in vitro seria atribuída à falha do explante em adquirir a necessária competência para a indução do processo (CRISTIANSON; WARNICK, 1998).

O sucesso das vias de regeneração in vitro pode ser influenciado por vários fatores, como o genótipo, o tipo de explante (segmento de epicótilo, segmento internodal, disco foliar, raiz), a idade e o tamanho dos explantes; os meios de cultura; as condições de cultivo; e os tipos e concentrações de reguladores vegetais, os quais se destacam como os principais controladores da morfogênese in vitro (THORPE, 1994; MOREIRA-DIAS et al., 2001). As diferentes fases da organogênese e os diferentes processos que ocorrem no nível celular durante o processo de regeneração in vitro, além dos diferentes estímulos aos quais os explantes são submetidos, são na verdade, a reprodução dos programas de desenvolvimento intrínsecos em condições artificiais (PERES, 2002). O controle adequado dessas condições é determinante no sucesso da regeneração in vitro.

As bases genéticas da capacidade de regeneração in vitro têm sido sido analisadas em grandes culturas como trigo, cevada, milho, arroz e tomateiro (HENRY et al., 1994a). No trigo, por exemplo, vários trabalhos foram realizados com as anteras ou com os embriões imaturos onde os mesmos foram submetidos a estudos de variação cromossômica através da adição, da substituição e da translocação nas regiões que afetam a formação de calos e a regeneração da planta (HENRY; De BUYSER, 1985; GALIBA et al., 1986; MATHIAS; FUKUI, 1986; FELSENBURG et al., 1987; HIGGINS; MATHIAS, 1987; SZAKÁCS et al., 1988; AGACHE et al., 1989; KALEIKAU at al., 1989; MŸLLER at al., 1989, 1990; CATTANEO at al., 1991; 
LANGRIDGE at al., 1991; LUCKETT et al., 1991; HENRY at al., 1994b). Tais estudos indicaram que possivelmente exista um sistema poligênico envolvendo vários cromossomos diferentes na morfogênese in vitro. Respostas da cultura de tecidos em cevada, milho e arroz foram analisadas por técnicas de genética quantitativa em combinação com o mapeamento por RFLP e vários locos quantitativos (QTLs) foram identificados (ARMSTRONG et al., 1992; MANO et al., 1996; TAGUCHI-SHIOBARA et al., 1997).

Em Arabidopsis, estudos demonstrararm que, para a indução de gemas caulinares in vitro a partir de explantes radiculares, é necessário a pré-incubação em meio indutor de calos (CIM), que contém altos níveis de auxina. Em seguida, os explantes precisam ser transferidos para o meio indutor de gemas caulinares (SIM), sendo que então os explantes se comprometem com a via de desenvolvimento de caules (VALVEKENS et al., 1988), como previamente descritos por Christianson and Warnick (1988). Segundo Gallois et al. (2002), entre os genes que aumentam a regeneração em Arabidopsis estão KNAT1 (KNOTTED-1 LIKE IN ARABIDOPSIS THALIANA), STM (SHOOT MERISTEMLESS) e WUS (WUSCHEL), que atuam na manutenção de células no estágio indeterminado. WUS e STM regulam a identidade das células iniciais, protegendo as células meristemáticas da diferenciação precoce, portanto mantendo as células meristemáticas indiferenciadas. No caso de KNAT1, os autores discutem que é apena expresso no meristema apical caulinar, deixando de ser expresso após determinação do órgão.

\subsection{Tomateiro como modelo para o estudo genético da regeneração in vitro}

Para a utilização de uma abordagem genética no estudo de possíveis novos genes ou alelos relacionados com a regeneração in vitro, faz se necessário a escolha de um modelo adequado. $O$ tomateiro, segundo a literatura, é um material adequado para a utilização das técnicas de cultura de tecidos, possivelmente por pertencer à família Solanaceae (HILLE et al., 1989; PATIL, 1994). Além disso, ele possui um genoma relativamente pequeno (905 Mb), mapas cromossômicos bem estruturados com marcadores clássicos e moleculares (RICK; YODER, 1988; TANKSLEY et al., 1992; 
LIMA et al., 2004), uma ampla riqueza de germoplasma constituída por 9 espécies selvagens do gênero Solanum seção Lycopersicum (LI; CHETELAT, 2010) que podem ser cruzadas com a espécie cultivada (STEVENS; RICK, 1986). O tomateiro também é uma espécie cultivada de grande importância econômica e apresenta frutos carnosos, o que possibilita estudos sobre o desenvolvimento desse tipo de órgão (HONG; LEE, 1993).

A capacidade para regeneração in vitro pode ser transferida de espécies selvagens (KOORNNEEF et al., 1986; PINO et al., 2010). Em estudos de regeneração da cultura de calos obtidos a partir de diferentes gerações de híbridos entre $S$. peruvianum e S. lycopersicum, Koornneef e colaboradores (1993) observaram que a capacidade de regeneração "doada" por $S$. peruvianum é controlada por dois alelos dominantes, denominados $R g 1$ e $R g 2$, onde a presença de apenas de um desses alelos, o $R g 1$, já é suficiente para conferir capacidade para regeneração de gemas caulinares oriundas de explantes radiculares. É interessante notar que somente um reduzido número de espécies selvagens de Solanum seção Lycopersicon possui a capacidade de regeneração a partir de explantes radiculares, sendo esta característica ausente em tomateiro (PERES et al., 2001). O RG1 foi mapeado no cromossomo 3 próximo ao loco yellow flesh (r) (KOORNNEEF et al., 1993). O alelo recessivo $r$ está presente em frutos de coloração verde ( $S$. peruvianum) e confere frutos de coloração amarelo quando passado através de cruzamentos ao tomateiro ( $S$. lycopersicon), sendo utilizado dessa maneira como marcador morfológico indicativo da presença de $R g 1$ (LIMA et al., 2004).

O tomateiro é um bom exemplo de uso bem sucedido de mutações que afetam genes de herança mendeliana no melhoramento (PINO et al., 2009). A combinação entre a elevada capacidade de regeneração com os tratamentos hormonais adequados é favorável para a elaboração de uma ferramenta inestimável para a genômica funcional em tomateiro (PINO et al., 2010).

\subsection{Ferramentas genéticas disponíveis em tomateiro}


A regeneração de plantas de tomateiro é conhecida por ser dependente do genótipo (TAN et al., 1987; KOORNNEEF et al., 1993) e diferenças na capacidade de regeneração in vitro têm sido amplamente relatadas em tomateiro (KUT; EVANS, 1982; KOORNNEEF et al., 1987, PERES et al., 2001). Estudos sobre a genética da regeneração de tomateiro tem demonstrado que esta característica é altamente hereditária (FRANKENBERGER et al., 1981) e de efeito dominante (OHKI et al., 1978; ADAM; QUIROS, 1985; WIJBRANDI et al., 1988).

O tomateiro cultivado representa apenas uma pequena fração da variabilidade genética que está disponível nas suas espécies selvagens. A taxa de progresso na melhoria de tomate com base na introdução das variações dessas espécies selvagens pode ser melhorada através do uso dos marcadores moleculares do tipo CAPS, RAPD,RFLP (TANKSLEY et al., 1992). A fim de utilizar o germoplasma das espécies selvagens na produção de um modelo de estudos genéticos, Eshed e Zamir (1994) desenvolveram um novo tipo de recurso composto de 50 linhas de S. lycopersicum onde cada uma possui um único fragmento introgredido da espécie selvagem de fruto verde S.pennellii (LA 716). Cada uma das linhas de introgressão é quase isogênica para o tomateiro cultivado e estas oferecem cobertura completa do genoma da espécie selvagem. Como podemos observar na Figura 1, S. pennellii (cromossomo escuro) foi o pai doador, doando um único segmento para cada um dos cromossomos de M82 (cromossomo vermelho). 


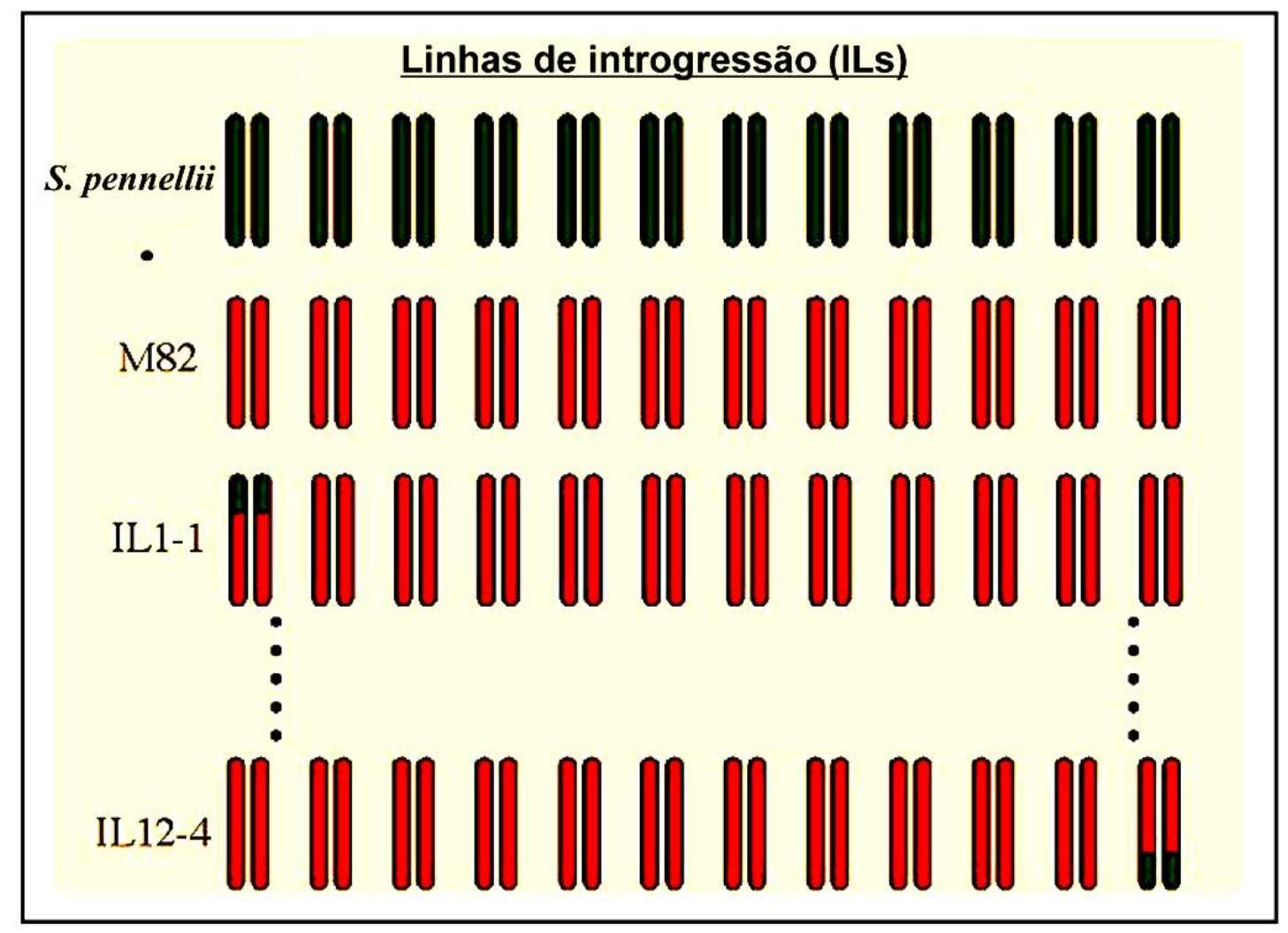

Figura 1 - Esquema de produção das ILs: Fragmentos da espécie selvagem S. pennellii (LA 716) sendo introgredidos na cultivar M82. Adaptado de http://zamir.sgn.cornell.edu/Qt//il story.htm

O grande desafio era desenvolver uma abordagem que correlacionasse as informações da sequência genética com suas funções biológicas. Uma estrutura para associar sequências de genes e fenótipos é definida como mapa de ligação genética. Diante de tal necessidade, Liu e Zamir (1999) criaram o conceito bin em tomateiro, que forneceu um método rápido para atribuir uma posição para cada sequência de DNA. Como podemos observar na Figura 2, a adesão de $S$. pennellii é representado por um par de cromossomos homólogos do doador (cromossomos verdes), o recorrente M82 (cromossomo vermelho) e seis ILs do cromossomo 1. As ILs que são homozigotas para os cromossomos vermelhos no resto do genoma constituem um conjunto de linhas quase isogênicas para o cromossomo 1. As seis ILs que cobrem o cromossomo 1 geram 10 caixas de mapeamento (bins $1 \mathrm{~A}$ - 1J), cada uma com uma composição única do pai doador (S. pennellii). A análise combinada dos dados para todas as linhas define um QTL que aumenta o valor fenotípico para o bin $1 \mathrm{C}$ e reduz o QTL para o bin $1 \mathrm{H}$. 


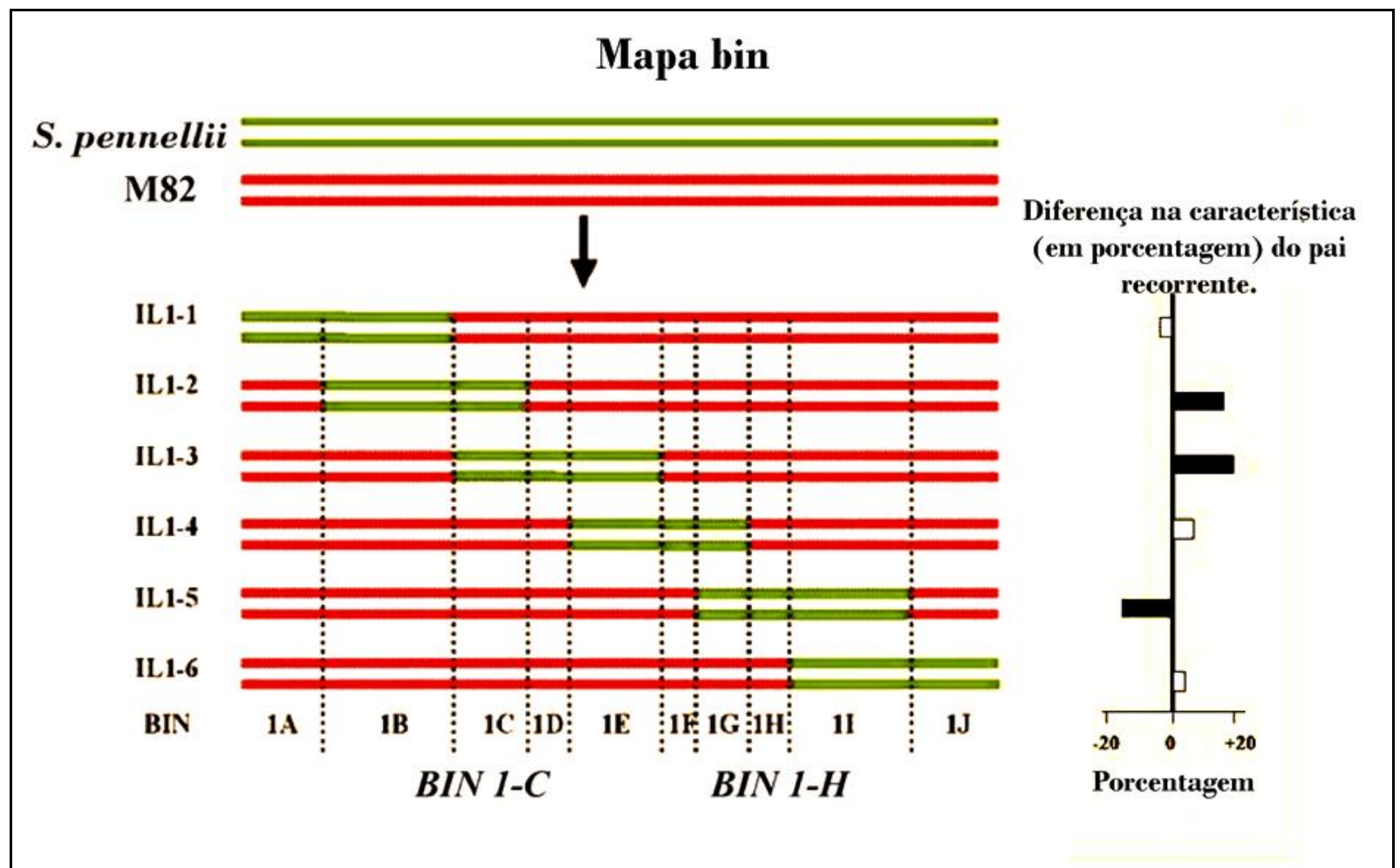

Figura 2 - Esquema de mapa bin: processo de elaboração da relação entre os fragmentos introgredidos de S. pennellii e sua posição em M82. Adaptado de http://zamir.sgn.cornell.edu/Qtl/il story.htm

Outra ferramenta que vem sendo muito utilizada em tomateiro é a cultivar MicroTom (MT), a qual pode ser considerada uma planta modelo (MEISSNER et al., 1997). Seu tamanho e ciclo de vida curtos são vantajosos e solucionam uma das principais limitações para a utilização intensa do tomateiro como modelo em abordagens genéticas de diversas questões fisiológicas (CAMPOS et al., 2010), como tem sido tradicionalmente feito com Arabdopsis thaliana. A cultivar MT possui altura entre 10 a 20 cm (EMMANUEL; LEVY, 2002), produz frutos e sementes viáveis em vasos de apenas 50-100 mL de substrato, completando seu ciclo em apenas 70-90 dias. Com essas características, a chamada cultivar Micro-Tom pode crescer em laboratório na mesma estrutura mínima requerida para Arabdopsis (CAMPOS et al., 2010). Além de existirem vários mutantes já introgredidos em MT (http://www.esalq.usp.br/tomato) e inúmeros outros trabalhos que utilizam a cultivar MT como planta modelo, como podemos verificar no trabalho proposto por Campos et al. (2009) com estudos de funções hormonais, ou em estudos de tolerrância ao cádmio em Gratão et al. (2009), ou no desenvolvimento de novos genótipos realizado por Lima et al. (2004). 


\subsection{Objetivo}

O objetivo do presente trabalho foi explorar as ferramentas, até então disponíveis em tomateiro, de modo a permitir uma abordagem genético-fisiológica no estudo da capacidade de regeneração in vitro.

Para tal objetivo, visamos alcançar as seguintes etapas:

I. Sabendo da elevada capacidade de regeneração de algumas espécies selvagens relacionadas ao tomateiro, analisar essa característica em Solanum pennellii.

II. Testar a capacidade de regeneração dos alelos selvagens disponíveis nos mutantes de MT

III.Testar as 50 ILs oriundas de S. pennellii e M82 e selecionar as que apresentaram maior regeneração.

IV. Introgredir possíveis novos genes ou alelos de Rg1 das ILs selecionadas no modelo MT.

V. Analisar através de marcadores moleculares o polimorfismo existente entre $S$. pennelli e MT nas gerações que foram introgredidas em MT. 


\section{MATERIAL E MÉTODOS}

\subsection{Material vegetal, reprodução e cultivo}

O tomateiro (Solanum lycopersicum L.) cv Micro-Tom (MT) e as linhas quase isogênicas de MT-Sp, MT-U e MT-D (CARVALHO et al., 2011) foram provenientes da coleção de mutantes de tomateiro mantidas na Escola Superior de Agricultura "Luiz de Queiroz" (ESALQ) da Universidade de São Paulo (USP) (http://www.esalq.usp.br/tomato/). A cv M82 e a coleção das 50 linhas de introgressão (ILs) derivada do cruzamento entre $S$. lycopersicum cv M82 x S. pennellii LA716 (ESHED; ZAMIR, 1994) foram fornecidos pelo Dr. Roger Chetelat do The CM Rick Tomato Genetics Resource Center (http://tgrc.ucdavis.edu/). As ILs selecionadas foram cruzadas e retrocruzadas com MT (receptor de pólen), utilizando o mesmo procedimento descrito anteriormente para a introgressão do alelo $R g 1$ em MT (PINO et al., 2010). Após cada retrocruzamento, as plântulas obtidas foram utilizadas como fonte de explantes (cotilédones com 12 dias de idade) para os ensaios de regeneração. As plântulas sem cotilédones foram mantidas in vitro para aclimatação em casa de vegetação, principalmente aquelas que apresentaram alta capacidade de regeneração de gemas caulinares, após 21 dias da sua correspondente cultura de cotilédones em meio SIM (Figura 3).

As plantas foram aclimatadas e cultivadas em casa de vegetação sob irrigação automática (quatro vezes ao dia), a uma temperatura média média de $28{ }^{\circ} \mathrm{C} ; 11,5 \mathrm{~h} / 13$ $\mathrm{h}$ (inverno / verão) de fotoperíodo e uma irradiância de 250-350 mmol m $\mathrm{m}^{-2} \mathrm{~s}^{-1}$ PAR , obtida por redução da radiação natural com uma malha refletora (Aluminet - Polysack Industrias Ltda, Leme, Brasil). As plantas foram cultivadas em vasos de $150 \mathrm{~mL}$ (MT) contendo uma mistura 1:1 de substrato comercial (Plantmax HT, Eucatex, São Paulo,

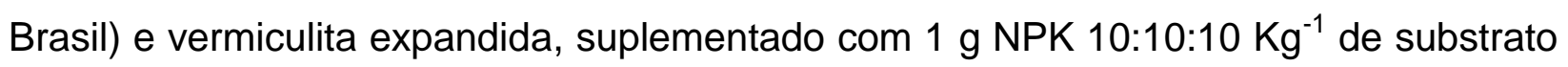
e $4 \mathrm{~g}$ de calcário dolomítico $\left(\mathrm{CaCO}_{3}+\mathrm{MgCO}_{3}\right) \mathrm{Kg}^{-1}$ de substrato. $\mathrm{Na}$ fase de floração (cerca de 35 dias desde a germinação) as plantas foram suplementadas com NPK (cerca de 0,2 g / $100 \mathrm{~mL}$ ). 


\subsection{Cultura in vitro}

Sementes de MT, MT-Sp, MT-U e MT - D, M82, S. pennellii LA716 e as linhas de introgressão (ILs) foram desinfestadas superficialmente em $100 \mathrm{~mL}$ de uma solução a $30 \%(\mathrm{v} / \mathrm{v})$ de alvejante comercial $(2,7 \%$ de hipoclorito de sódio) com duas gotas de detergente comercial, durante 15 min sob agitação, seguido de três lavagens com água esterilizada em autoclave. As sementes foram então colocadas para germinar em meio de cultura com metade dos nutrientes de MS (MURASHIGE; SKOOG, 1962), metade de vitaminas B5 (GAMBORG; MILLER; OJIMA, 1968); $15 \mathrm{~g} \mathrm{~L}^{-1}$ de sacarose e $6 \mathrm{~g} \mathrm{~L}^{-1}$ agar (Merck, Darmstadt, Alemanha). $\mathrm{O}$ pH do meio foi ajustado para 5,8 antes da esterilização em autoclave. Cerca de 40 sementes foram semeadas por frasco contendo $30 \mathrm{~mL}$ de metade de meio de cultura MS. Os frascos foram selados com PVC e incubados a $25 \pm 1{ }^{\circ} \mathrm{C}$ no escuro por $4 \mathrm{~d}$, seguido por 4 ou $8 \mathrm{~d}$ de $16 \mathrm{~h}$ de fotoperíodo fornecida por uma lâmpada de $40 \mathrm{~W}$ fluorescente branco frio (c. $45 \mu \mathrm{mol}$ PAR $\mathrm{m}^{-2} \mathrm{~s}^{-1}$ ).

Os cotilédones foram isolados com 8 ou 12 dias de idade das plântulas. As pontas proximal e distal foram removidas, e os cotilédones foram divididos transversalmente em dois ou três explantes. Os explantes foram colocados com a face abaxial em contato com o meio imediatamente após o isolamento, sendo utilizados 15 explantes por placa de Petri $(90 \times 15 \mathrm{~mm})$, com 6 placas por tratamento. Para tanto, foi utilizado o Meio de Indução de Gemas (SIM), composto por sais de MS com vitaminas B5, $30 \mathrm{~g} \mathrm{~L}^{-1}$ de sacarose, $6 \mathrm{~g}$ de ágar $\mathrm{L}^{-1}, 5 \mu \mathrm{M}$ BAP (Sigma, St Louis, EUA), ou Meio de Indução de Raízes (RIM), que tem a mesma composição do SIM, exceto pela substituição de BAP por 0,4 $\mu \mathrm{M}$ ANA (Sigma, St Louis, EUA). As concentrações das soluções estoques utilizadas foram $5 \mu \mathrm{M}$ BAP $(0,0548 \mathrm{~g}$ em $50 \mathrm{~mL}$ de água $)$ e 0,4 $\mu \mathrm{M}$ ANA $(0,0037 \mathrm{~g}$ em $50 \mathrm{~mL}$ de água). Para cada $1 \mathrm{~L}$ de meio de cultura final foi utilizado 1 $\mathrm{mL}$ dessas soluções estoques, já que são 1000x concentradas. As soluções estoques de hormônios foram preparadas por dissolução de sais com gotas de $\mathrm{HCl} 1 \mathrm{M}$ (BAP) ou $\mathrm{KOH} 1 \mathrm{M}$ (ANA), antes de adicionar água destilada. Todos os hormônios foram esterilizados por filtração $(0,2 \mathrm{~mm})$ antes de serem adicionados ao meio estéril. $\mathrm{O} \mathrm{pH}$ das soluções estoques de hormônios não foi ajustado e eles foram adicionados, sob condições estéreis, após ajuste de pH e da esterilização do meio em autoclave. 
Nenhuma alteração no pH do meio final foi observado após as adições das soluções estoques de hormônios. Durante o processo de obtenção dos explantes, uma placa de Petri contendo sais de permanganato de potássio foi mantida dentro da capela de fluxo laminar para tentar minimizar o acúmulo de etileno, o qual pode reduzir a taxa de regeneração do tomateiro (LIMA et al., 2009). As placas foram vedadas com parafilme e mantidas sob $16 \mathrm{~h}$ de fotoperíodo a $25 \pm 1^{\circ} \mathrm{C}$ por 3 semanas. Após 21 esse período, tanto o teste de capacidade de formação de gemas caulinares quanto 0 de raízes foram avaliados contando a quantidade de raízes completamente desenvolvidos por explante e calculando a porcentagem de explantes com gemas caulinares.

No caso do teste da segregação da capacidade de formação de gemas caulinares nos retrocruzamentos com MT, para facilitar o processo de triagem, os experimentos foram conduzidos separando os explantes cotiledonares da planta de origem. As placas de Petri foram divididas em quadrantes e enumeradas, sendo o mesmo realizado com os frascos contendo a plântulas doadoras. Desse modo, após a identificação dos explantes com maior capacidade de formação de gemas caulinares, suas plântulas doadoras foram aclimatadas em casa de vegetação para prosseguir com os cruzamentos. 


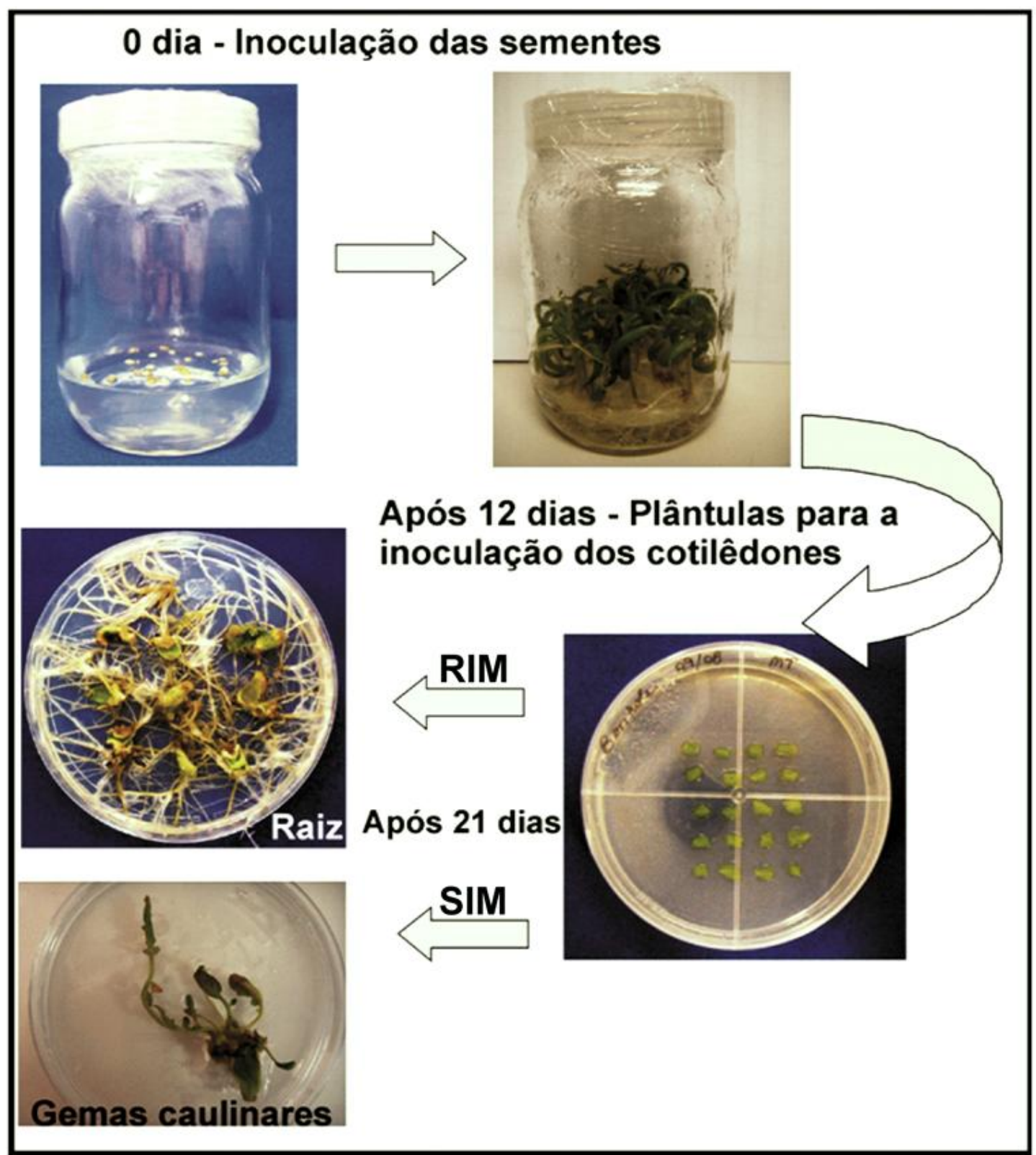

Figura 3 - Esquema de inoculação das sementes e obtenção dos explantes cotiledonares e das gemas caulinares e radiculares

\subsection{Cruzamentos}

O processo de introgressão dos alelos candidatos foi realizado conforme ilustrado na Figura 4. Para tal, o pólen foi extraído, com auxílio de uma escova de dentes elétrica adaptada, das flores recém abertas das plantas selecionadas (ILs e plântulas aclimatadas após seleção in vitro). As flores do receptor MT foram 
emasculadas, utilizando-se uma pinça $n^{0} 2$, quando as pétalas mudaram da cor verde para o amarelo, mas ainda continuavam fechadas, garantindo que os óvulos dessa flor ainda não haviam sido autofecundados. O pólen, recém extraído e armazenado em geladeira em tubos de micro centrífuga, foi aplicado sobre os estigmas das flores do receptor MT um dia após a emasculação.

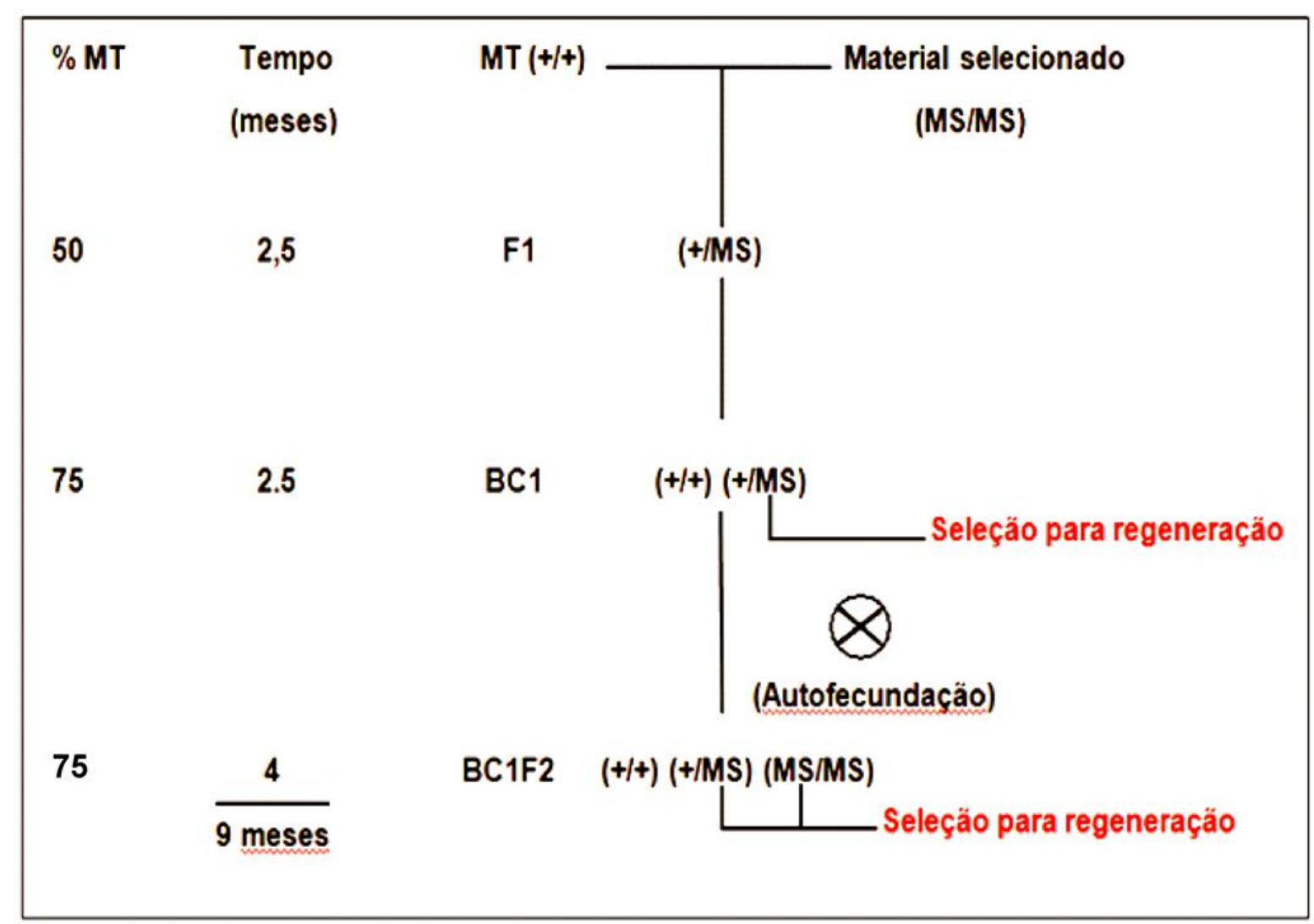

Figura 4 - Esquema de introgressão de um gene dominante. MT= cv Micro- Tom, MS = Material selecionado, $\mathrm{F} 1=$ geração $\mathrm{F} 1, \mathrm{BC}=$ backcross

Para maiores detalhes sobre cruzamentos acessar a página:

http://www.esalq.usp.br/docentes/lazaropp/MMTCap3Cruzamentos.pdf

\subsection{Processamento das sementes}

Aproximadamente 40 dias após cada cruzamento, os frutos maduros foram colhidos e as sementes removidas com a polpa e mantidas durante 24 horas sob 
fermentação num copo plástico contendo água e fermento biológico liofilizado (Saccharomyces cerevisiae, Fermix, São Paulo, Brasil) para facilitar a retirada da mucilagem que fica ao redor da semente. Em seguida, as sementes foram lavadas em água corrente, despejadas sobre papel, no qual foram deixadas secar ao ar livre na sombra, durante 2-3 dias. As sementes foram retiradas do papel, colocadas em envelopes de alumínio e armazenadas em caixas contendo dessecante (silíca ou sulfato e cálcio) sob refrigeração $\left(7\right.$ a $\left.14^{\circ} \mathrm{C}\right)$.

\subsection{Análise molecular}

O DNA genômico foi extraído, segundo Fulton et al. (1995), a partir de 100 mg de folhas de plântulas que foram colocadas em um tubo Eppendorf de 1,5 mL e maceradas com nitrogênio líquido. Posteriormente, foram preparadas as soluções estoques do tampão de Extração de DNA (TED), Tampão de Lise (TL) e Tampão de Micro-Prep (TMP), o qual é uma mistura de TED e TL (FULTON et al., 1995) que foram mantidas em temperatura ambiente. Foram adicionados $200 \mu \mathrm{L}$ de TMP ao tecido que foi novamente macerado, sendo acrescentados mais $550 \mu \mathrm{L}$ de TMP e agitados em vortex. A solução foi então incubada a $65{ }^{\circ} \mathrm{C}$ em banho-maria por 60 minutos. O tubo foi completado com uma solução de clorofórmio / isoamílico (24:1), cerca de $500 \mu \mathrm{L}$ e novamente, cada tubo foi levado ao vortex. Depois os tubos foram centrifugados a $10.000 \mathrm{rpm}$ por 5 minutos onde a fase aquosa foi pipetada e transferida para novos tubos, sendo adicionado o mesmo volume recuperado de isopropanol frio para precipitar o DNA. Imediatamente após ser centrifugado a $10.000 \mathrm{rpm}$ por 5 minutos, o isopropanol foi descartado e o pellet formado foi lavado com etanol $70 \%$ e seco deixando-se os tubos invertidos em papel toalha por cerca de 30 minutos .O DNA foi ressuspendido em $50 \mathrm{uL}$ de Tampão TE e colocado a $65^{\circ} \mathrm{C}$ por 15 minutos. DNA foi novamente centrifugado por 10 minutos a $10.000 \mathrm{rpm}$ e armazenado a $-20^{\circ} \mathrm{C}$.

Os marcadores CAPs foram previamente definidos no TOMATO-EXPEN 2000 disponível em Sol Genomics Network - SGN (http://solgenomics.net/) e amplificados usando primers específicos (Tabela 1) para as regiões cromossômicas que contem as ILs 3-2, 7-1 e 8-3. Cada reação de $25 \mu \mathrm{L}$ continha $1 \mathrm{U}$ de Taq DNA Polimerase; $1 \mathrm{X}$ 
tampão de Taq DNA Polimerase (Fermentas); 0,2 mM dNTP; 1,5 mM MgCl2; 0,2 $\mu \mathrm{M}$ de cada iniciador e 0,8 ng de DNA. As etapas de amplificação consistiram na desnaturação inicial de $94^{\circ} \mathrm{C}$ por 5 min, seguido de 40 ciclos de $94^{\circ} \mathrm{C}$ por $40 \mathrm{~s}, 55^{\circ} \mathrm{C}$ por $30 \mathrm{~s} \mathrm{e} 72^{\circ} \mathrm{C}$ por $60 \mathrm{~s}$; com extensão final à $72^{\circ} \mathrm{C}$ por $5 \mathrm{~min}$. Os fragmentos amplificados foram analisados por eletroforese em gel de 1,0\% agarose em tampão 1X SB (preparado a partir de 20X SB, o qual consiste em $8 \mathrm{~g} \mathrm{NaOH}$ diluído em $1000 \mathrm{~mL}$ de água, acrescido de ácido bórico até $\mathrm{pH}$ 8.0). A cada uma das amostras foi adicionado um volume adequado de tampão de carregamento contendo o corante SYBR Gold nucleic acid gel stain (Invitrogen). Posteriormente foi realizada a disgestão dos produtos de PCR com as enzimas descritas na Tabela 1. Cada reação de $25 \mu \mathrm{L}$ continha $21 \mu \mathrm{L}$ do produto da reação de PCR, $5 \mathrm{U}$ da enzima de restrição e $1 \mathrm{X}$ do tampão específico (Fermentas). Os fragmentos digeridos foram analisados por eletroforese em gel de 1,5\% agarose em tampão $1 \mathrm{X} \mathrm{SB}$, sendo adicionados o volume adequado de tampão de carregamento contendo o corante SYBR Gold nucleic acid gel stain (Invitrogen). 
Tabela 1 - * marcadores CAPs de polimorfismo entre S. pennellii (pen) e Micro-Tom (lyc)

\begin{tabular}{|c|c|c|c|c|c|c|c|}
\hline$\#$ & $\begin{array}{c}\text { SGN } \\
\text { ID }\end{array}$ & Bin & Posição & $\begin{array}{c}\text { Sequencia } \\
\text { F / R (5'- 3') }\end{array}$ & Enzima & $\begin{array}{l}\text { Tamanho } \\
\text { lyc / pen }\end{array}$ & $\begin{array}{r}\mathrm{MgCl}_{2} \\
(\mathrm{mM}) \\
\end{array}$ \\
\hline \multirow[t]{2}{*}{ P1 } & T1388 & $3 C$ & $47 \mathrm{cM}$ & $\begin{array}{c}\text { GCGATTTGGCTAT } \\
\text { CTGGGTA }\end{array}$ & Hinf I & $\begin{array}{l}350+200 \\
480+270\end{array}$ & 3 \\
\hline & & & & $\begin{array}{c}\text { AACCGAAAGGCTT } \\
\text { TTCCAAG }\end{array}$ & & & \\
\hline \multirow[t]{2}{*}{ P2 } & T1359 & $8 \mathrm{~F}$ & $73 \mathrm{cM}$ & $\begin{array}{c}\text { TTTGAGAGGCATG } \\
\text { ATGGTCA }\end{array}$ & Acil & $\begin{array}{l}400+335 \\
515+335\end{array}$ & 1.5 \\
\hline & & & & $\begin{array}{c}\text { TCCCACCGGTTAA } \\
\text { ACTCATC }\end{array}$ & & & \\
\hline \multirow[t]{2}{*}{ P3 } & T1255 & $7 \mathrm{H}$ & $82 \mathrm{cM}$ & $\begin{array}{c}\text { TTTGCTTTGCTTCT } \\
\text { CCTTCA }\end{array}$ & Alul & $\begin{array}{l}320+200 \\
350+220\end{array}$ & 1.5 \\
\hline & & & & $\begin{array}{c}\text { (ATTCAACTCGAGC } \\
\text { AACGTCA }\end{array}$ & & & \\
\hline \multirow[t]{2}{*}{ P4 } & TG294 & $8 \mathrm{~F}$ & $87 \mathrm{cM}$ & $\begin{array}{c}\text { ATTGGCTGCAATG } \\
\text { ATGGATT }\end{array}$ & Alul & $\begin{array}{l}800 \\
900\end{array}$ & 1.5 \\
\hline & & & & $\begin{array}{c}\text { CTAAGCAGGACGG } \\
\text { CCATCTA }\end{array}$ & & & \\
\hline \multirow[t]{2}{*}{ P5 } & CT114 & $7 \mathrm{H}$ & $96 \mathrm{cM}$ & $\begin{array}{c}\text { ATTGAAGAATGGC } \\
\text { GGTGAAG }\end{array}$ & Dral & $\begin{array}{l}800+300 \\
800+325\end{array}$ & 1.5 \\
\hline & & & & $\begin{array}{c}\text { ATGCCAACTTCTTG } \\
\text { GCAAAC }\end{array}$ & & & \\
\hline
\end{tabular}

*Os marcadores foram definidos previamente em Tomato-EXPEN 2000 de Sol Genomics Network - SGN (http://solgenomics.net/search/markers) 


\section{RESULTADOS}

\subsection{Análise do efeito dos alelos selvagens: Self pruning (Sp), Dwarf (D) e Uniform ripening $(U)$ na regeneração in vitro.}

Atento ao fato de que algumas espécies selvagens de frutos verdes relacionadas ao tomateiro possuem alta regeneração in vitro (KUT; EVANS, 1982; KOORNNEEF et al., 1997; PERES et al., 2001), no presente trabalho testamos essa capacidade para S. pennellii (Figura 5), uma espécie de fruto verde e morfologicamente (Figura 5B) distinta do tomateiro cultivado (Figura 5C). A alta capacidade de formação de gemas caulinares in vitro em $S$. pennellii foi evidente quando comparada com a cultivar MT em explantes cotiledonares com 8 e 12 dias de idade cultivados em Meio MS com 5,0 $\mu$ M BAP (Figura 5A). Surpreendentemente, também observamos uma alta capacidade de formação de gemas caulinares na cv M82, quando comparado ao MT (Figura 5A). Uma vez que a capacidade de regeneração da cv MT é considerada equivalente à da maioria das cultivares de tomateiro (PERES et al., 2001), pode ser que algumas mutações conhecidas e presentes na cv M82 possuam algum impacto na capacidade de formação de gemas caulinares. Como muitas outras cultivares de tomateiro para processamento industrial (mollhos e ketchups), a cv M82 abriga os alelos recessivos uniform fruit $(u)$ e self-pruning $(s p)$, que conferem a ausência de ombro verde nos frutos (YEAGER, 1935) e hábito de crescimento determinado (PNUELI et al., 1998), respectivamente. Uma vez que estas mesmas mutações também estão presentes em MT (CAMPOS et al., 2010), é pouco provável que elas possam explicar a alta capacidade de formação de gemas caulinares de M82, quando comparada ao MT. Assim, os resultados de NILs com os alelos do tipo selvagem Sp (Figura 5D) e $U$ (Figura 5F) introgredidos em MT mostraram que esses locos não afetam significativamente a capacidade de formação de gemas caulinares em explantes cotiledonares, quando comparado com o controle MT (Figura 5A). O porte reduzido de MT é causado pelo alelo recessivo dwarf (d) (MARTí et al., 2006), uma mutação relacionada com brassinosteróides (BISHOP et al., 1999). Uma NIL que abriga o tipo selvagem desse alelo $D$ (Figura $5 \mathrm{E}$ ) também foi testado. No entanto, 
nenhuma diferença significativa na formação de gemas caulinares em explantes de cotilédones foi encontrada comparando-se MT- $D$ com MT, o que indica que o alelo $d$ presente em MT não está afetando a sua capacidade de regeneração (Figura 5A). 


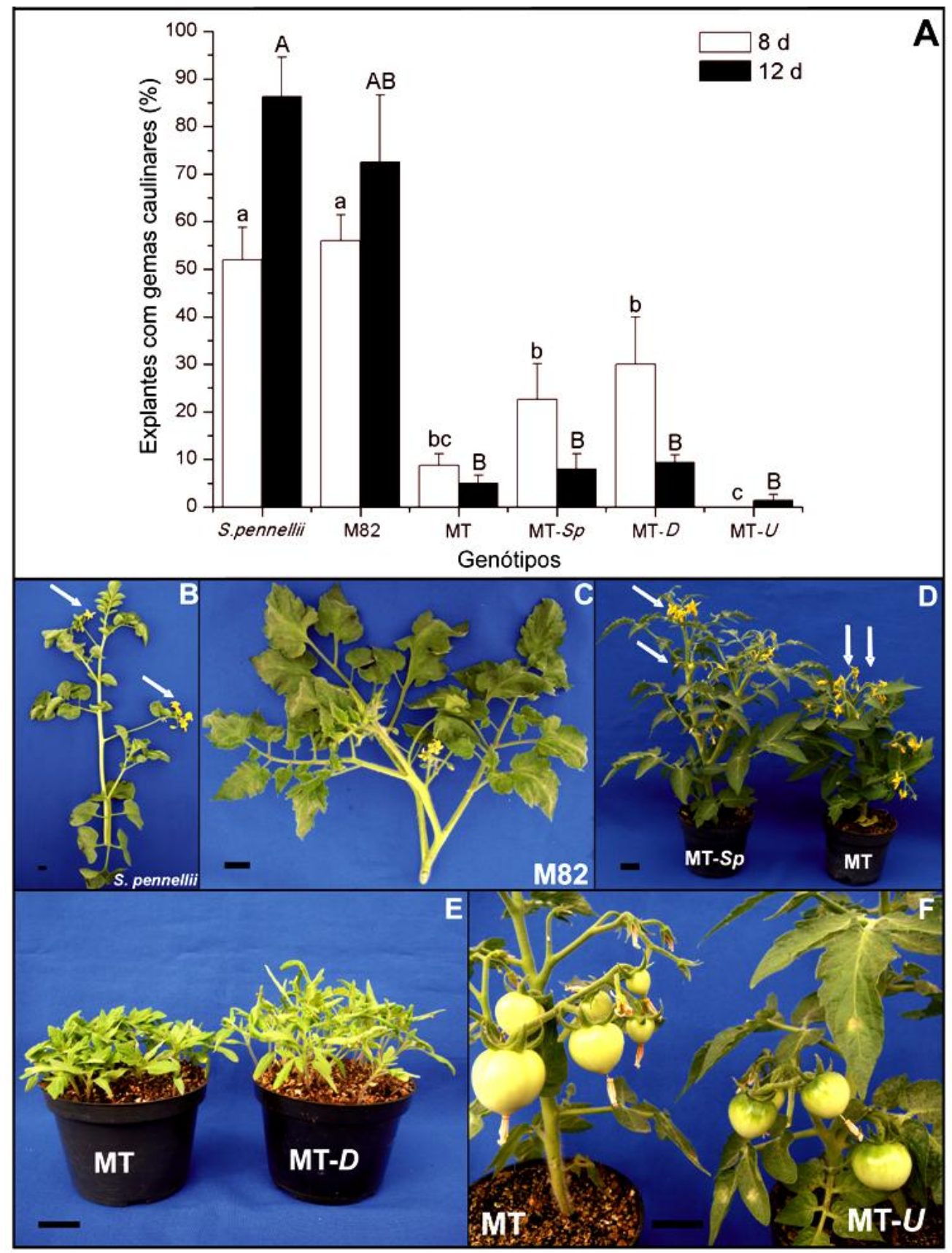

Figura 5 - Capacidade de regeneração in vitro de gemas caulinares da espécie selvagem Solanum pennellii LA716 e diferentes genótipos de tomateiro (S. lycopersicum). (A) Cotilédones com 8 e 12 dias de idade (após a germinação) foram cultivados durante 21 dias em meio MS acrescido de 5,0 $\mu \mathrm{M}$ BAP. As cultivares testadas foram o tomateiro M82 e Micro-Tom (MT), bem como linhagens quase isogênicas (NILs) a MT que abrigam os alelos do tipo selvagem $S p$ (crescimento indeterminado), $D$ (não anão) e $U$ (frutos com ombros verdes). M82 tem os alelos mutados $s p$ e $u$, e MT tem os alelos $s p, u$ e $d$. (B-F) Prancha das plantas de S. pennellii (B), M82 (C), MT-Sp (D), MT-D (E) e MT-U (F). As setas estão indicando índices simpodial (número de folhas entre duas inflorescências consecutivas) igual a 2, em S. pennellii (B), 3 na MT-Sp (D, à esquerda) e zero em MT (D, à direita). As barras representadas com a mesma letra minúscula (8 dias) e letra maiúscula (12 dias) não diferem significativamente $(P>0,05)$ de acordo com o tteste Student não pareado ( $\mathrm{n}=6$ placas de Petri, cada uma contendo 15 cotilédones). Barra de escala $=$ $2 \mathrm{~cm}$ (B-F) 


\subsection{Seleção das ILs quanto a capacidade de regeneração}

Embora tenhamos observado que a capacidade de regeneração é mais contrastante quando se compara $S$. pennellii com MT do que com M82 (Figura 5A), o cruzamento entre M82 $\times$ S. pennellii pode produzir uma população de plantas adequada para se estudar a segregação de locos que controlam a capacidade de formação de gemas caulinares in vitro, pois tais locos podem ser complementares entre os dois genitores. Este parece ser o caso, uma vez que fomos capazes de observar uma variação considerável na capacidade de formar gemas caulinares em explantes cotiledonares cultivados in vitro em uma população de ILs abrigando pequenos segmentos de $S$. pennellii introgredidos na cv M82 (Figura 6). Entre as ILs observadas, as ILs 2-1, 3-1, 6-3 e 7-5 apresentaram a menor formação de gemas caulinares in vitro (Figura 6), quando comparado com ambos genitores. Tais ILs podem estar representando locos onde os alelos de S. pennellii são inferiores ao de M82. Esta baixa capacidade de regeneração poderia ser apenas o efeito dos alelos de $S$. pennellii ou o efeito das interações epistáticas desses alelos com outros presentes em M82, o que explicaria, neste último caso, a natureza transgressiva (DeVicente and Tanksley 1993) da segregação (resultados inferiores a ambos parentais). Por outro lado, as ILs 3-2, 6-1, 7-1, 7-2, 8-2, 8-3, 9-1, 9-2, 10-2 e 10-3 podem representar alelos superiores presentes em $S$. pennellii que controlam a capacidade de formar gemas caulinares in vitro. Usando o conceito de mapeamento de BIN criado para esta mesma população de ILs (LIU et al., 2003), foi possível classificar as regiões cromossômicas com maior probabilidade de abrigarem os alelos para alta capacidade de formação de gemas caulinares nas caixas 3C (IL3-2), 6A (IL6-1), 7H (ILs 7-1 e 7-2), 8F (ILs 8-2 e 8-3), 9DE (ILs 9-1 e 9-2) e 10F (ILs 10-2 e 10-3) (ver Fig. 2, Anexo A). Entre as ILs com alta frequência de formação de gemas caulinares, as ILs 3-2, 7-1 e 8-3 também apresentaram maior quantidade de gemas formadas por explante, assemelhando-se ao parental S. pennellii (Figura 7).

Em experimentos independentes, foi confirmada a alta freqüência de explantes formando gemas caulinares nas ILs 3-2, 6-1, 7-1, 8-3, 9-1 e 10-2, que apresentaram uma capacidade de regeneração que não foi estatisticamente diferente da elevada 
formação de gemas caulinars no parental S. pennellii (Figura 8A). Testes realizados nas plântulas F1 do cruzamento das ILs com MTindicaram que a capacidade de regeneração de gemas caulinares provavelmente se comporta como dominante, ou pelo menos parcialmente dominante, em todas as ILs testadas. Por outro lado, testes feitos em plantas F1 vindas do cruzamento de M82 com MT sugerem um comportamento recessivo para a capacidade de regeneração vinda da cv M82 (Figura 8B). A natureza dominante da alta capacidade de formação de gemas caulinares apresentada pela ILs nos permitiu testar a sua interação em plântulas F1 a partir de diferentes combinações entre IL $\times$ IL. Os resultados mais proeminentes de tal teste foram os efeitos negativos da combinação das ILs 3-2 e 6-1, e a tendência da IL8-3 de melhorar a capacidade de regeneração em diferentes combinações (Figura 8C). A figura 8B também mostra que as as ILs 7-1 e 7-2 possuem capacidade de regeneração equivalentes, mesmo em heterozigose. Desse modo, a região cromossômica advinda de S. pennellii compartilhada por ambas ILs representa a caixa 7H (Figura 9), sendo um dos 6 bins anteriormente mencionados. Em outros experimentos, apenas a IL7-1 foi utilizada como representante do bin $7 \mathrm{H}$, sendo esse também o caso das ILs 8-3 (bin 8F), 9-1 (bin 9DE) e 10-2 (bin 10F). 


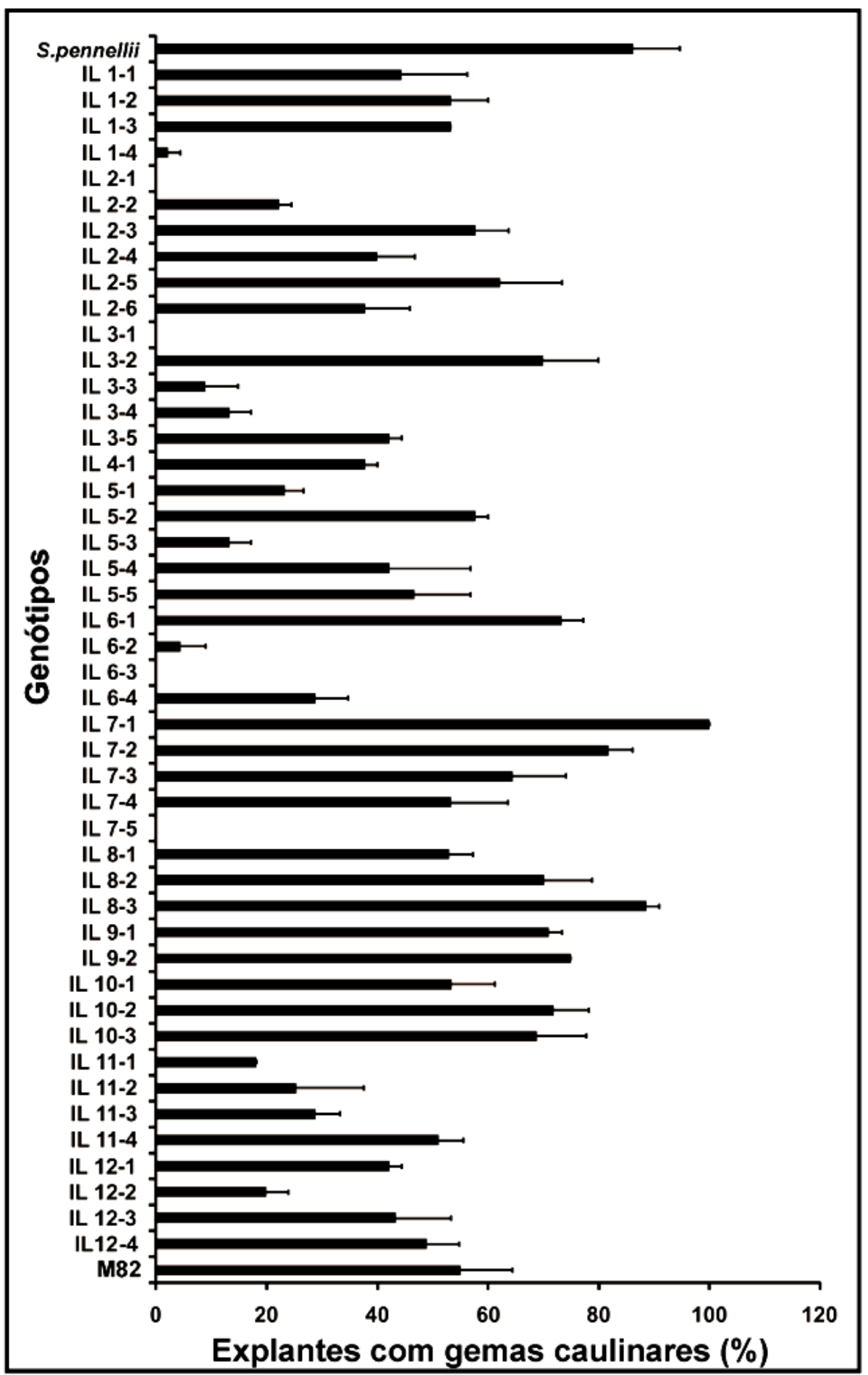

Figura 6 - Capacidade da regeneração in vitro de gemas caulinares provenientes de cotilédones com 12 dias de idade das linhas de introgressão (ILs), que contém segmentos cromossômicos $S$. pennellii LA716 introgredidos na cv M82. Os números de cada IL representam o cromossomo e o segmento, em que estão localizados respectivamente. Os explantes cotiledonares foram cultivados em meio MS acrescido de 5,0 $\mu \mathrm{M}$ BAP por 21 dias. Barras verticais representam o erro padrão, $\mathrm{n}=6$ placas de Petri, cada uma contendo 15 explantes cotiledonares 


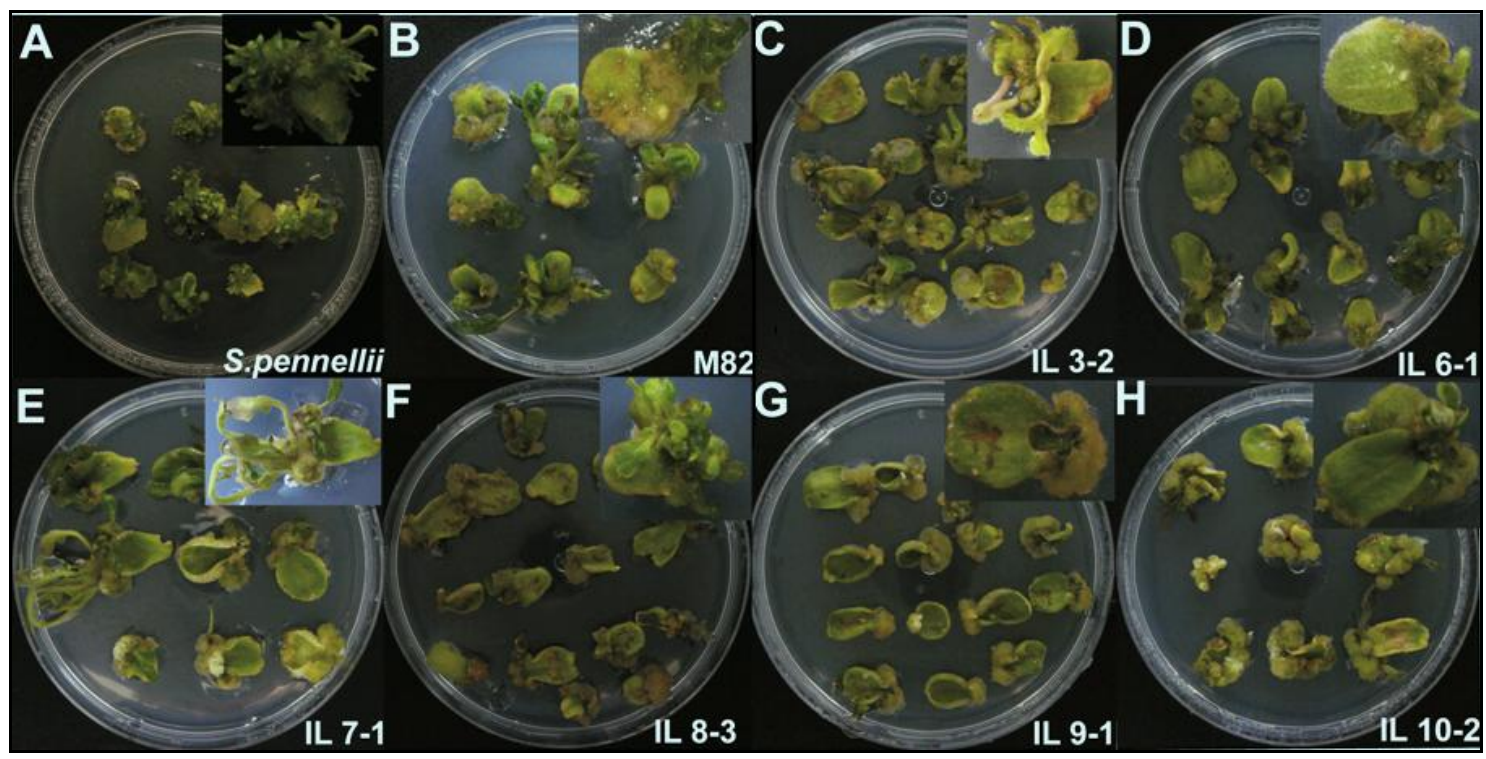

Figura 7 - Prancha de regeneração de gemas caulinares do genótipos selecionados. Explantes cotiledonares com 12 dias de idade dos genótipos de S. pennellii LA716 (A), cv M82 (B), IL3-2 (C), IL6-1 (D), IL7-1 (E), IL8-3 (F), IL9-1 (G) e IL10-2 (H) foram cultivados em meio MS acrescido de 5,0 $\mu$ M BAP por 21 dias 


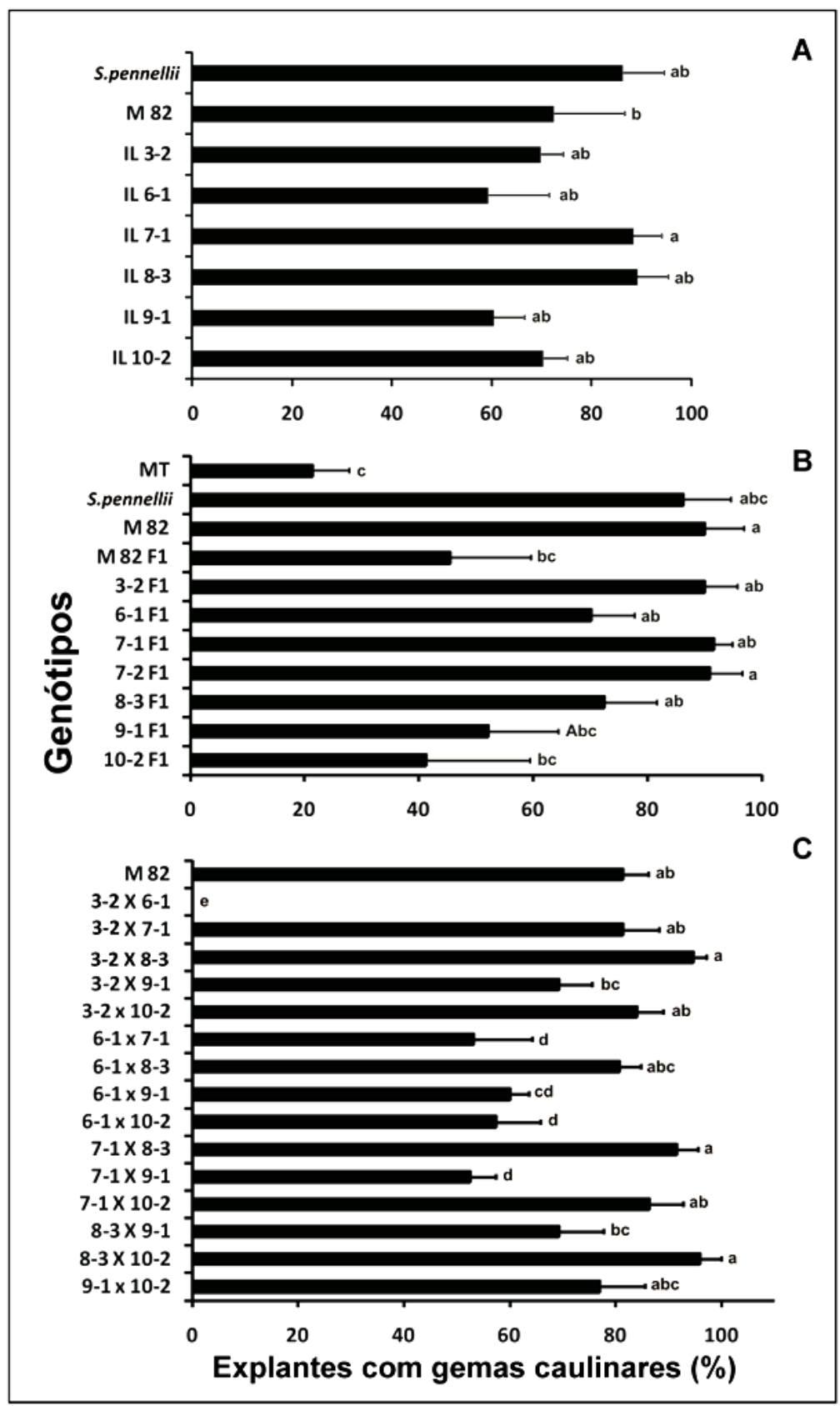

Figura 8 - Capacidade de regeneração de gemas caulinares das linhas de introgressão (ILs) selecionadas e seus cruzamentos. (A) Formação de gemas caulinares de explantes cotiledonares com 12 dias de idade de S. pennellii LA716, cv M82 e ILs selecionadas. (B) Formação de gemas caulinares em explantes cotiledonares de plântulas em F1 derivadas do cruzamento entre Micro-Tom (MT) x ILs. (C) Formação de gemas caulinatres em explantes cotiledonares de 12 dias de idade em plântulas derivadas de diferentes combinações de cruzamentos IL x IL. Os explantes cotiledonares foram cultivados em meio MS acrescido de 5,0 $\mu \mathrm{M}$ BAP por 21 dias. As barras representadas com a mesma letra não diferem significativamente $(P>0,05)$ de acordo com o teste $t$ de Student não pareado $(n=6$ placas de Petri, cada uma contendo 15 explantes cotiledonares) 


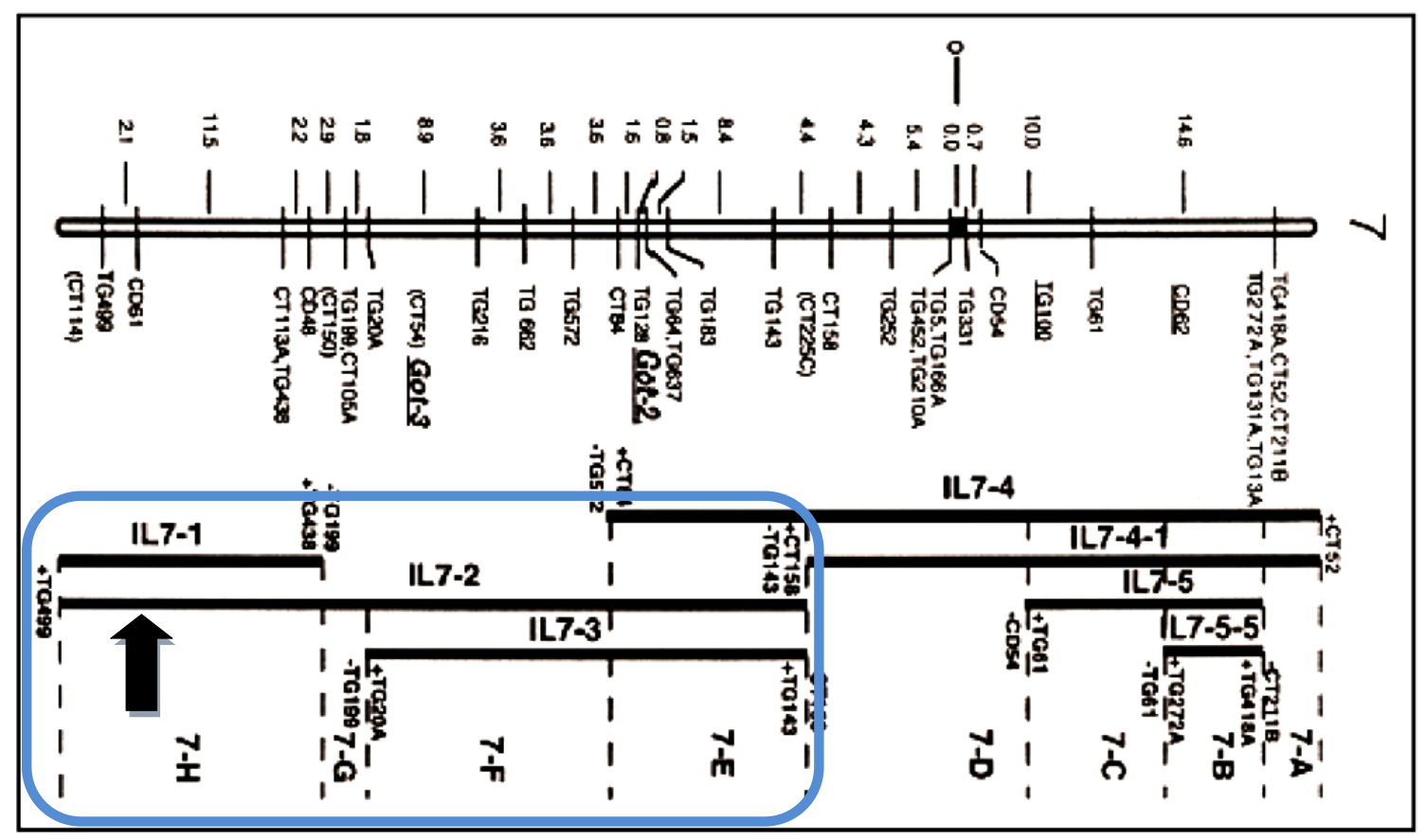

Figura 9 - Região de interseção das ILs 7-1 e 7-2. Todas as linhas de introgressão do cromossomo 7 com seus respectivos BINs. A seta indica o fragmento cromossômico oriundo de $S$. pennellii comum às ILs 7-1 e 7-2, definido como 7-H. Adaptado de Eshed e Zamir (1994)

\subsection{Verificação da capacidade das ILs para a formação raízes}

Nas ILs que apresentaram alta capacidade de formar gemas caulinares, também foi testada a capacidade para a formação de raízes no meio de cultura RIM $(0,4 \mathrm{mM}$ ANA). A capacidade de formação de raízes foi alta em relação a M82 nas ILs 3-2, 8-3, 10-2 e, em menor intensidade, na IL 7-1 (Figura 10), indicando que os alelos apresentados por essas ILs estão controlando a formação de tanto gemas caulinares quanto raízes. Por outro lado, as ILs 6-1 e 9-1 parecem melhorar especificamente a formação de gemas caulinares (Figura $8 \mathrm{~A}$ ), mas não a formação de raízes (Figura $10 A)$. 


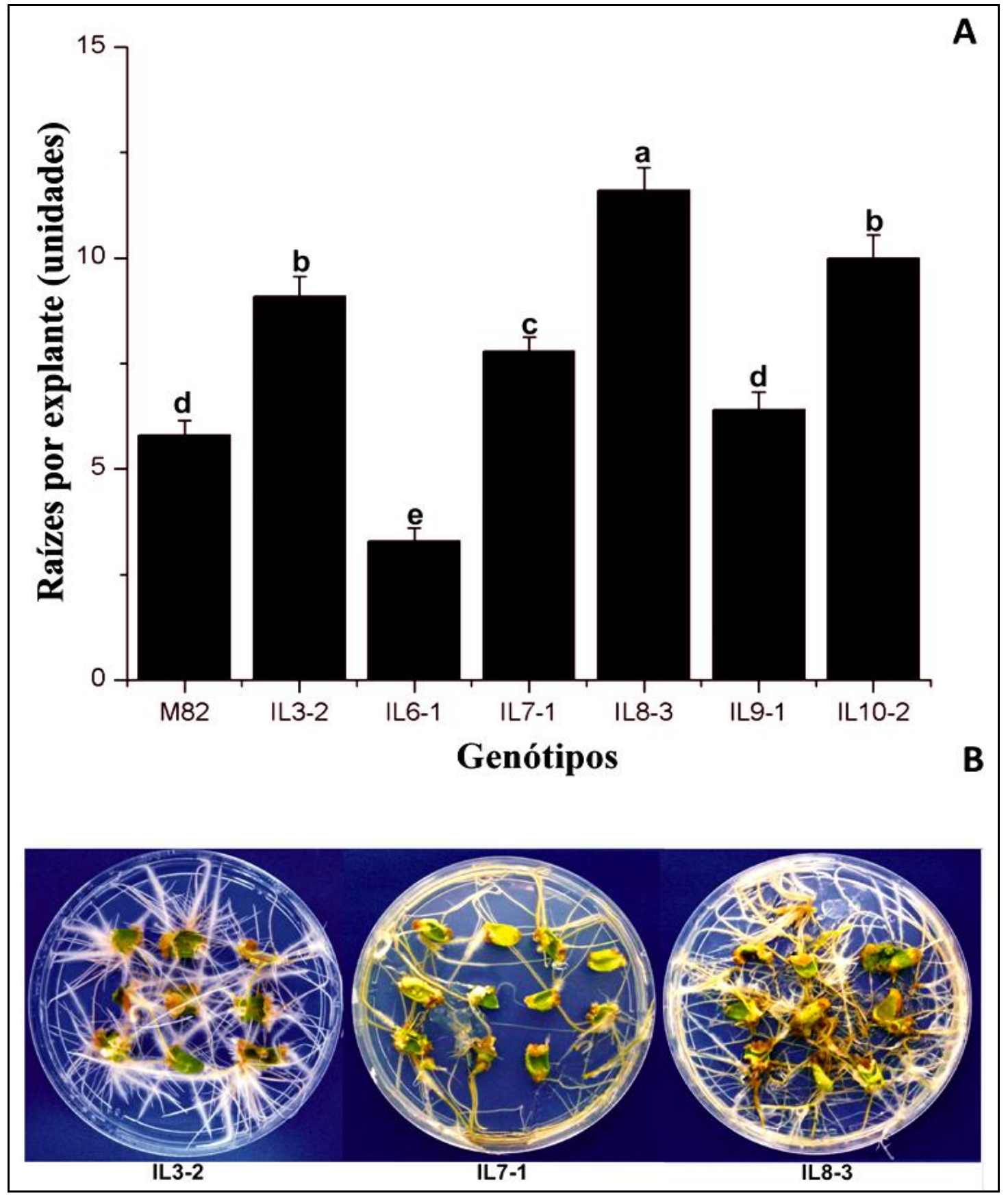

Figura 10 - Capacidade de regeneração de raízes das linhas de introgressão (ILs) selecionadas. (A) Número de raízes formadas por explante cotiledonar obtidos a partir de plântulas com 12 dias de idade. (B) Prancha representante dos explantes cotilédones regenerados. Os explantes foram cultivados em meio MS acrescido de 0,4 $\mathrm{MM}$ ANA durante 21 dias. As barras representadas com a mesma letra não diferem significativamente $(P>0,05)$ de acordo com o teste t de Student não pareado $(n=6$ placas de Petri, cada uma contendo 15 explantes cotiledonares) 


\subsection{Retocruzametos das ILs selecionadas com a planta modelo MT e análise molecular}

A fim de criar NILs e aprofundar o estudo do efeito dos alelos presentes nas ILs 3-2, 7-1 e 8-3, começamos a introgressão, por meio de retrocruzamentos sucessivos (BC), dessas ILs com a cv MT. Na geração do primeiro retrocruzamento (BC1 e $\mathrm{BC} 1 \mathrm{~F} 2)$ foi possível selecionar plântulas de diferentes cruzamentos apresentando alta capacidade de formação de gemas caulinares quando comparado com os valores médios obtidos no parental MT (Figura 11). Considerando a introgressão da capacidade de regeneração elevada na IL3-2, as plantas que apresentaram maior regeneração foram 21, 23 e 24 (Figura 11A). O marcador CAPS T1388 (Tabela 1), desenvolvido para a região que abrange o bin $3 \mathrm{C}$, mostrou que tais plantas podem ser homozigota para o alelo de S. pennellii (planta 23), homozigota para o alelo de MT (planta 24) e heterozigota (planta 21). é (Figura 12A). Consistentemente, a planta 23 apresentou frutos amarelos (dados não apresentados), o que evidencia a homozigose do alelo recessivo $r$ de $S$. pennellii que mapeia nessa mesma região. Foram selecionadas cinco plantas BC1 derivadas do cruzamento com a IL 7-1 que apresentaram alta capacidade de regeneração da parte aérea (plantas 5, 8, 14, 17 e 23) e uma (planta 6) com baixa capacidade (Figura 11B). A análise dessas plantas com dois marcadores CAPs presentes na região do bin $7 \mathrm{H}$ (Tabela 1) indicou que a planta 6 é homozigota para o alelo presente em MT (Figuras 12C-D) e que as plantas com alta capacidade de regeneração são heterozigotas para o alelo de $S$. pennellii, pelo menos com base no marcador CT114 (Figura 12D), com exceção da planta 14, homozigota para o alelo MT no mesmo marcador. Quanto ao cruzamento da IL 8-3 com MT, duas plantas com alta capacidade de regeneração de gemas caulinares (plantas 16 e 17) foram obtidas em BC1 (Figura 11C). A planta 17, a única que sobreviveu a aclimatação em casa de vegetação, demonstrou ser homozigota para o alelo MT (Figuras 12B e D) nos dois marcadores testados para o bin 8F (Tabela 1).. Assim, tal planta, e também a planta 24, derivadas da IL 3-2, e 14, derivada da IL 7-1, podem representar segmentos cromossômicos menores de $S$. pennellii inseridos no genoma MT, o que contribuirá para a criação de NILs em retrocruzamentos subsequentes. 


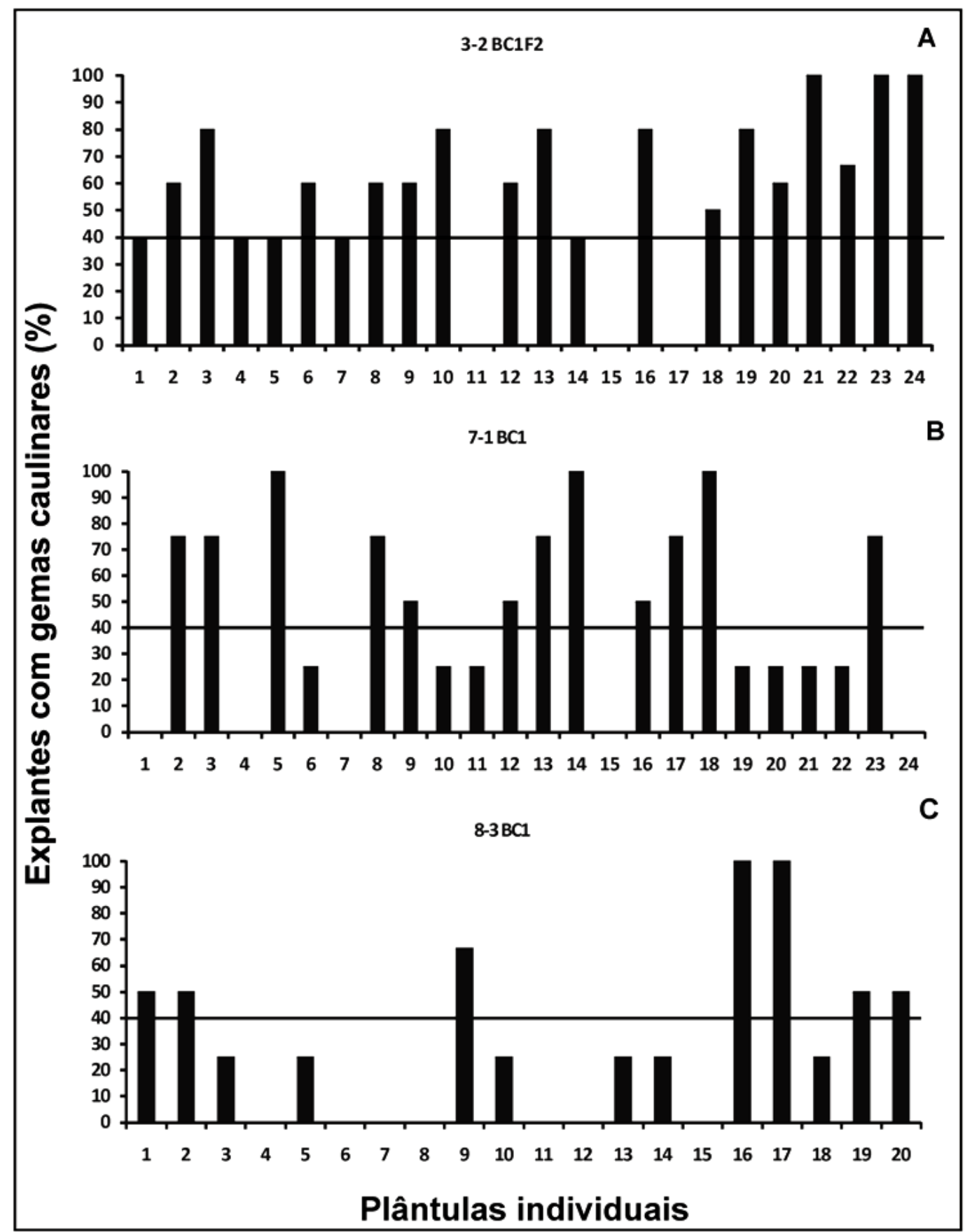

Figura 11 - Triagem das plântulas regenerantes do cruzamento Micro-Tom (MT) x ILs (ver Figura 4). (A) Capacidade de regeneração de gemas caulinares de plântulas em BC1F2 derivado do cruzamento MT x IL3-2. (B) Capacidade de regeneração das plântulas em BC1 do cruzamento MT x IL7-1. (C) Capacidade de regeneração de gemas caulinares das plântulas em BC1 a partir do cruzamento MT x IL8-3. Os explantes cotiledonares de doze dias de idade foram cultivados em meio MS acrescido de 5,0 $\mu \mathrm{M}$ BAP por 21 dias. As linhas horizontais representam a capacidade média de regeneração do controle MT 


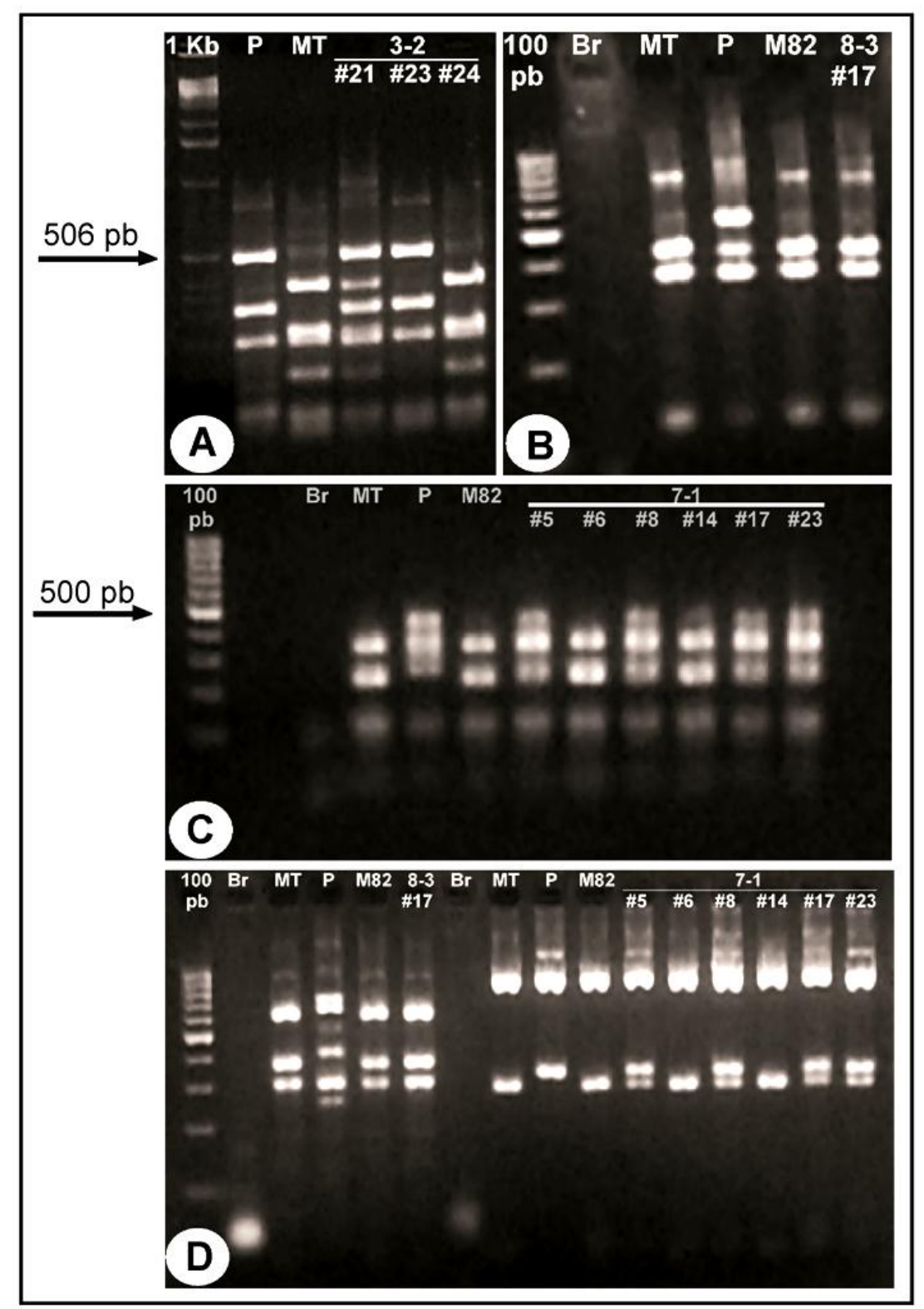

Figura 12 - Polimorfismo do DNA entre S. Iycopersicum cv Micro-Tom e S. pennellii para as regiões cromossômicas que abrangem os bins apresentando alta capacidade de regeneração (ver Tabela 1). (A) DNA amplificado com iniciadores T1388 (P1), e digerido com Hinf I, dos genótipos S. pennellii (P), Micro-Tom (MT) e plantas \# 21, \# 23 e \# 24 em BC1F2, derivada da IL3-2 (ver fig. 6A). (B) DNA amplificado com iniciadores T1359 (P2), e digerido com Aci I, dos genótipos de MT, S. pennellii (P), M82 e planta \# 17 em BC1, derivado da IL8-3 (ver fig. 6B). (C) DNA amplificado com iniciadores T1255 (P3), e digerido com Alu I,dos genótipos MT, S. pennellii (P), M82 e plantas \# 5, \# 6, \# 8, \# 14, \# 17 e \# 23 em BC1, derivadas da IL71 (ver fig. 6B). (D) Esquerda: DNA amplificado com iniciadores TG294 (P4), e digerido com Alu I, dos genótipos MT, S. pennellii (P), M82 e planta \# 17 em BC1, derivada da IL8-3. Direita: DNA amplificado com iniciadores CT114 (P5), e digerido com Dra I, dos genótipos MT, S. pennellii (P), M82 e plantas \# 5, \# 6, \# 8, \# 14, \# 17 e \# 23 em BC1, derivado da IL71 (ver fig. 6B). A banda de $1 \mathrm{~Kb}(\mathrm{~A})$ e $100 \mathrm{pb}(\mathrm{BD})$ foram utilizadas como marcadores moleculares de DNA. Br significa PCR controle sem DNA 


\section{DISCUSSÃO}

No presente trabalho foram identificados seis segmentos cromossômicos cujos alelos da espécie selvagem de tomateiro $S$. pennellii melhoraram a organogênese in vitro. Estes segmentos, que representam QTL (PARAN; ZAMIR, 2003) para capacidade de regeneração in vitro, foram nomeados, de acordo com Liu et al. (2003), como RG3C, RG6A, RG7H, RG8F, RG9DE e RG10F. Ao estudar a base genética da capacidade da organogênese in vitro em $S$. peruvianum, Koornneef et al. (1987) descobriram que essa característica era associada a dois alelos dominantes principais (nomeados $R g 1$ e $R g$ 2). O $R g 1$ foi mapeado no cromossomo 3, próximo ao loco yellow fresh (r) (KOORNNEEF et al., 1993). O RG3C descrito aqui pode ser o equivalente de S. pennellii para o $R g 1$ descoberto em S. peruvianum por Koornneef et al. (1993), uma vez que $R g 1$, e o loco yellow fresh (r), mapeiam no mesmo bin 3C (LIU et al., 2003). Pode ser também que alguns dos outros locos aqui descritos correspondem ao $R g 2$ (KOORNNEEF et al., 1987), embora não temos informações sobre sua posição no mapa para comparação. A nome $R g 2$ também foi usado para descrever um gene dominante que controla a elevada capacidade de regeneração de gemas caulinares a partir de explantes de raiz de S. chilense (SATOH et al., 2000). Uma vez que este gene foi mapeado na mesma posição de $R g 1$, e consequentemente $R G 3 C$, no cromossomo 3 , é provável ser outro alelo para o mesmo loco.

\subsection{As possíveis funções dos genes para os locos de controle da organogênese in vitro}

Os locos RG3C, RG7H, RG8F e RG10F aqui descritos estão controlando a elevada capacidade de formação tanto de gemas caulinares quanto de raízes in vitro, quando colocados em meios adequados. Os outros dois locos, RG6A e RG9DE, parecem ser específicos para a capacidade de formação de gemas caulinares. Christianson e Warnick (1988) dividiram o processo de organogênese in vitro nas seguintes etapas: 1) desdiferenciação, 2) aquisição de competência, 3) indução, 4) 
determinação, 5) diferenciação e 6) formação de órgão. Nesta divisão, a etapa de aquisição de competência é um processo necessário para formação tanto de caules quanto de raízes, enquanto que a indução requer um balanço auxina-citocinina específico (SKOOG; MILLER, 1957), o que torna esta etapa restrita para formar gemas caulinares ou raízes. Com base neste conceito, propõe-se aqui que $R G 3 C, R G 7 H$, RG8F e RG10F estão provavelmente afetando a etapa de aquisição de competência, e que RG6A e RG9DE estão afetando o passo de indução da parte aérea (Figura 13). Uma conseqüência importante do trabalho de Christianson e Warnick (1988) é que a competência pode ser oposta à determinação, uma vez que um explante muito comprometido (determinado) para uma via particular de desenvolvimento provavelmente será mais recalcitrante (não competente) para assumir uma via diferente. Um estudo clássico de determinação de células foi realizado por Mary Tran Thanh Van (1973), a qual demonstrou que explantes epidérmicos de hastes florais de tabaco tendem a continuar a formar novas flores in vitro. Esses conceitos podem prever a posterior determinação da identidade genética de $R G 3 C, R G 7 H, R G 8 F$ e $R G 10 F$, uma vez que podem representar genes ligados à especificação do destino celular ou aumentar a população de células indeterminadas (células-tronco) em um dado explante (SUGIMOTO et al., 2011). É interessante notar que dosagens hormonais mostraram que $R g 1$ não confere um aumento nos níveis endógenos de citocinina, embora aumente a produção de gemas caulinares in vitro (BOITEN et al., 2004). Como genes levando à acumulação de citocinina irão favorecer um balanço citocinina-auxina que induzirá gemas caulinares, mas não raízes (PERES; KERBAUY, 1999; ESTRUCH et al., 1991; CATTEROU et al., 2002), os resultados de Boiten et al. (2004) são consistentes com a identidade proposta para $R g 1$ e $R G 3 C$ como sendo controladores da competência para formação tanto de raízes quanto de gemas caulinares, ao invés da indução específica de caules.

Quanto às possíveis identidades de RG6A e RG9DE, suas induções específicas de gemas caulinares in vitro podem sugerir como candidatos genes de controle da produção ou da sensibilidade à citocinina, bem como genes de identidade do meristema caulinar. Assim, sabe-se que as diferenças genéticas que levam ao aumento de citocinina na planta, também aumentam a capacidade de formação de 
gemas caulinares in vitro (PERES; KERBAUY, 1999; ESTRUCH et al., 1991; CATTEROU et al., 2002). Além disso, a expressão de genes que controlam a resposta a citocinina ou a identidade de células meristemáticas caulinares, como ARABIDOPSIS RESPONSE REGULATOR5 (ARR5), SHOOTMERISTEMLESS (STM), WUSCHEL (WUS), CUP-SHAPED COTYLEDON1 e 2 (CUC1 e CUC2), correlacionam-se com a formação de gemas caulinares adventícias e também podem ser utilizados como marcadores para esta capacidade (GALLOIS et al., 2002; CARY et al., 2002; CHE et al., 2006, 2007). A produção de NILs para RG6A e RG9DE, tais como o esforço descrito aqui para $R G 3 C, R G 7 H, R G 8 F$ (Fig. 11-12), irá ser útil para estudos futuros envolvendo a expressão de genes candidatos e dosagens hormonais em comparação com o genótipo de referência. Neste trabalho, o genótipo escolhido foi o Micro-Tom (MT), devido ao seu porte reduzido e ciclo de vida curto (CAMPOS et al., 2010) e a disponibilidade de mutantes que afetam o metabolismo e a sensibilidade hormonal em uma mesma base genética (CARVALHO et al., 2011). Tais mutantes hormonais e outros mutantes que afetam o processo de desenvolvimento disponível em MT (www.esalq.usp.br / tomate), permitem a abordagem de análise de duplos mutantes, uma vez que as NILs que afetam a regeneração in vitro são produzidas na mesma base genética. Além disso, o uso de NILs, que isolam uma única região QTL, transformará a tarefa de clonagem de QTL em algo semelhante ao realizado para os genes de comportamento mendeliano (PARAN; ZAMIR, 2003).

No momento, e de posse de marcadores que delimitam cada bin, foi possível fazer listas de genes relevantes que mapeiam nessas regiões (ver Anexo B). Embora seja prematuro propor genes candidatos para serem os responsáveis pelas diferenças de capacidade de regeneração, foi possível identificar que em alguns bins aqui estudados existem mutações conhecidas que podem servir de macadores morfológicos para a introgressão da alta capacidade de regeneração. Desse modo, no bin $3 \mathrm{C}$ foram identificadas os genes correspondentes às mutações white flower (wf) e yellow flesh $(r)$ e no bin $7 \mathrm{H}$, as mutações cujos genes estão presentes são lateral suppresser (Is) e flacca $(f l c)$. Alem disso, pode não ser coincidência que as 4 invertases de parede celular conhecidas em tomateiro estão nos bins 10F ( Lin6 e Lin 8) e 9DE (Lin5 e Lin7). Entre elas, chama a atenção Lin6, a qual se expressa em raízes e calos, além de ser 
induzida por citocinina (GODT; ROITSCH, 1997). Levando se em conta que o tomateiro é conhecido por não ser capaz de regenerar a partir de explante radicular (PERES et al., 2001) e que a formação de calos está negativamente relacionada com a capacidade de formar órgãos (LIMA et al., 2009), pode se especular que a expressão de Lin6, induzida por citocinina em raízes ou calos formados a partir de outros explantes, pode estar negativamente afetando a capacidade de regeneração. Estudos futuros investigando que tipo de transportador de membrana (sacarose ou hexose) é mais comum nos tecidos colocados in vitro poderão confirmar se alelos com menor ativiade de Lin6 podem favorecer a regeneração in vitro.

Um outro tipo de proteínas presente em praticamente todos os bins foram as GRAS (ver Anexo B). A presença de tais proteínas chama a atenção, já que são marcadores da presença de células tronco (SUGIMOTO et al., 2011). 


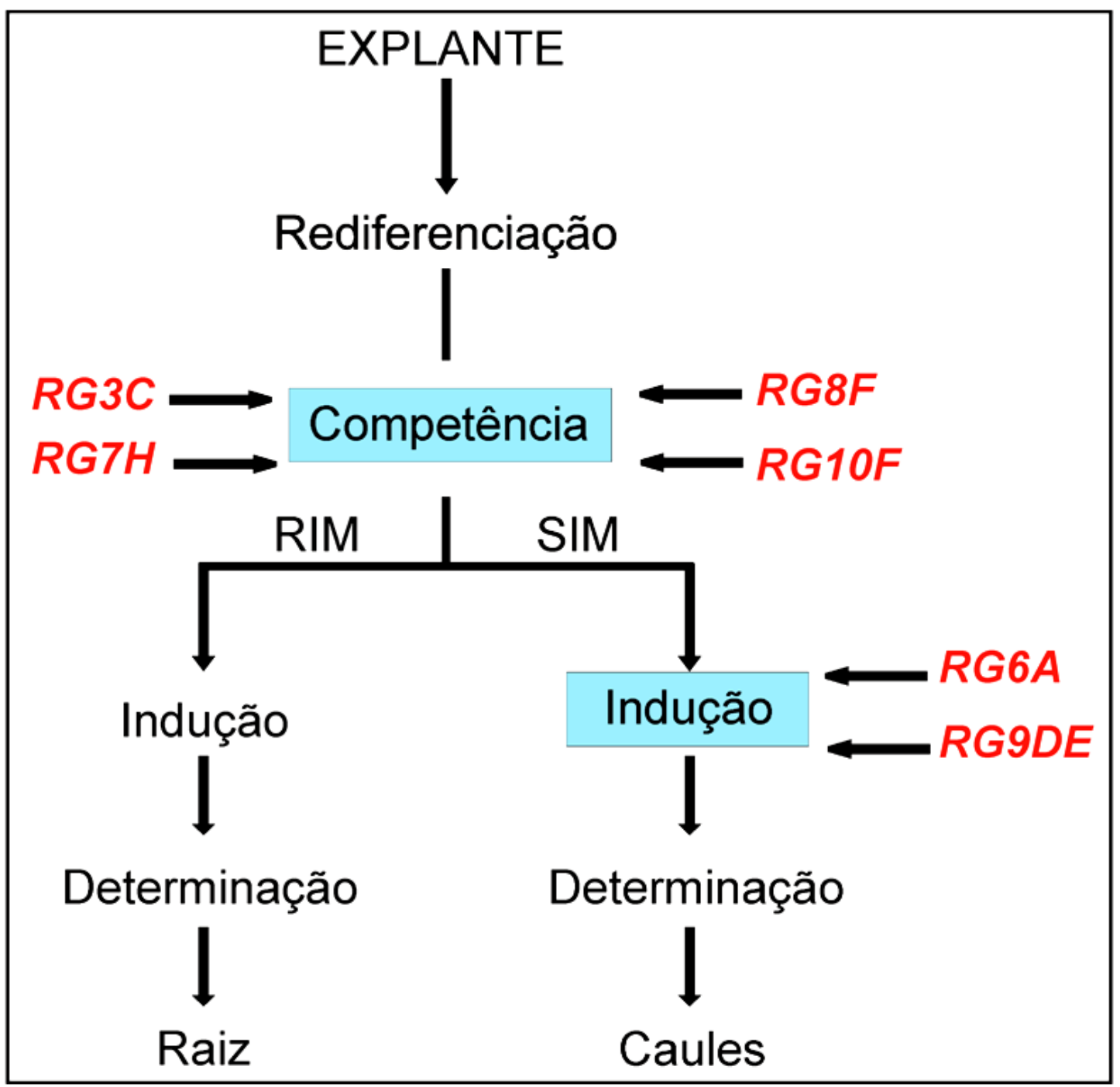

Figura 13 - Hipótese de trabalho para o posicionamento dos alelos aqui identificados no esquema proposto por Christianson e Warnick (1988). Os alelos que melhoraram tanto a capacidade de regeneração de gemas caulinares quanto a de formação de raízes, provavelmente, podem estar afetando a etapa de aquisição de competência, que é compartilhada por ambos órgãos (SUGIMOTO et al., 2010). Por outro lado, alelos que melhoraram apenas a capacidade de regeneração de gemas caulinares, provavelmente estão afetando a etapa de induçãode órgãos específicos. A nomenclatura para os alelos foi estabelecida após sua posição no mapeamento BIN (LIU et al., 2003)

\subsection{Implicações para a evolução e domesticação do tomateiro}

Além de mutações induzidas, a variação genética natural (ALONSO-BLANCO; KOORNNEEF, 2000) é um recurso valioso no tomateiro e outras epécies cultivadas, especialmente como fonte de alelos do tipo selvagem para os locos cujas versões 
desses genes já foram nocauteados nos tomateiros cultivados .O comportamento dominante dos alelos controlando a regeneração in vitro de espécies selvagens de tomateiro descritas aqui e por outros autores (KOORNNEEF et al., 1987; de FARIA et al., 2002) sugere que eles podem ter perdido suas funções durante a domesticação do tomateiro ou terem sido eliminados por estarem ligados a genes deletérios ou por apresentarem efeito pleiotrópico. No caso de $R G 3 C$, deve-se notar que ele está ligada loco yellow flesh $(r)$, que normalmente é indesejado pelo produtor, uma vez que a seleção é realizada para tomates de frutos vermelhos. Além disso, foi relatado que o alelo $R g 1$, e talvez outros locos que melhoram a formação de gemas caulinares in vitro, produz um fenótipo pleiotrópico de plantas com alta ramificação (LIMA et al., 2004). A prática comum da eliminação de ramos laterais (HEUVELINK; BUISKOOL, 1995) é menos importante no caso das cultivares determinadas (por exemplo cv M82) utilizadas para o processamento industrial (ketchup e molhos). Contudo, a necessidade de desbrota nas cultivares de crescimento indeterminado pode ter levado a alguma seleção indireta negativa para os alelos capazes de melhorar a formação de gemas caulinares ex vitro e in vitro,.

Uma questão intrigante é qual seria a função, no ambiente natural, dos genes que melhoram a regeneração artificial in vitro. É sabido que o desenvolvimento pósembrionário de plantas sésseis, isto é, a formação contínua de órgãos ao longo do seu ciclo de vida, permite-lhes explorar melhor o ambiente para lidar com o estresse (FOSKET, 1994). Desse modo, os alelos que melhoram a formação de brotações adventícias irão favorecer a sobrevivência após episódios de fogo (KAUFFMAN, 1991) e herbivoria (van der MEIJDEN et al., 1988). Quanto à capacidade de formar raízes adventícias, além de sua importância para lidar com inundações (MANO et al., 2005) e para melhorar a alocação de nutrientes (OCHOA et al., 2006), os alelos que aumentam esta capacidade podem ser especialmente úteis em plantas alastrantes e nãotrepadeira como tomateiro. A capacidade de formar raízes adventícias ao longo do caule em contato com o solo pode permitir a mineração de nutrientes em novas superfícies e também o reinício de um novo sistema radicular que substitui as raízes atacadas por patógenos (GRIEVE, 1941). É interessante notar que, diferente de seu ambiente original, o tomateiro domesticado é conduzido como uma trepadeira, além de 
ser selecionado para o crescimento determinado, e para resistência a agentes bióticos (patógenos e insetos) e abióticos (STEVENS; RICK, 1986). É tentador especular que capacidades úteis no ambiente natural, e que se tornaram obsoletas durante a domesticação, são agora necessárias novamente para a biotecnologia moderna.

\subsection{Implicações para a biotecnologia e melhoramento do tomateiro}

Independentemente da identidade genética dos locos aqui descritos, a utilidade dos genes que conferem maior capacidade de regeneração in vitro é evidente não apenas no tomateiro, mas para a maioria das espécies cultivadas. Apesar da transformação de plantas mediada por Agrobacterium ter sido estabelecida há um bom tempo para o tomateiro (FILLATI et al., 1987), este procedimento vem sendo continuamente melhorado, com contribuição fundamental de alelos que melhoraram a regeneração in vitro (PINO et al., 2010). O efeito aditivo visto aqui em cruzamentos entre IL x IL sugere que a piramidação de alelos diferentes em um único genótipo contribuirá para melhorar ainda mais o cultivo in vitro do tomateiro. Além disso, até o presente momento, a ferramenta de produção de duplos haplóides (FORSTER; THOMAS, 2005) e, portanto, o o melhoramento reverso (DIRKS et al., 2009) ainda é indisponível no tomateiro. A principal barreira para a produção de haplóides no tomateiro está na baixa regeneração de anteras quando cultivadas em diferentes meios (SEGUÍ-SIMARRO et al., 2011). Uma vez que alguns dos alelos descritos aqui controlam a fase de competência, eles podem ser úteis para o melhorardiferentes sistemas de regeneração in vitro. 


\section{CONCLUSÕES}

Com base nos resultados obtidos no presente trabalho, conclui-se que:

- Atento ao fato de que algumas espécies de frutos verdes de tomate estão relacionadas com a alta regeneração in vitro (KUT; EVANS, 1982; KOORNNEEF et al., 1997; PERES et al., 2001), no presente trabalho comprovamos essa capacidade para S. pennellii;

- Surpreendentemente, também observamos uma alta capacidade de formação de gemas caulinares na cv M82. No entanto, isso não nos impediu de testarmos as linhas de introgressão (ILs), uma população oriunda do cruzamento entre M82 x S. pennellii, na identificação de locos que controlam a capacidade de formação de gemas caulinares in vitro;

- Análises realizadas nos alelos selvagens: Self pruning (Sp), Dwarf (D) e Uniform ripening $(U)$ mostraram não influenciar na capacidade de regeneração;

- Das 50 ILs testadas, foram selecionadas as ILs 3-2, 6-1, 7-1, 8-3, 9-1 e 10-2 para elevada capacidade de regeneração de gemas caulinares, porém somente as ILs 3-2, 7-1, 8-3 e 10-2 foram significativas para a regeneração radicular, indicando possivelmente estarem relacionadas com a fase de competência, enquanto que as ILs 6-1 e 9-1 podem estar relacionadas com a fase de indução na organogênese;

- Foi possível transferir os alelos de alta capacidade de regeneração para o modelo genético Micro-Tom.

Desse modo, tem-se como perspectiva: 
- A introgressão completa dos alelos selecionados para o sistema modelo genético Micro-Tom, que irá favorecer a caracterização e o isolamento de genes importantes para estudos de desenvolvimento de plantas e aplicações biotecnológicas. 


\section{REFERÊNCIAS}

ADAMS, T.L.; QUIROS, C.F. Somatic hybridization between Lycopersicon peruvianum and $L$. penelli: regenerating ability and antibiotic resistance as selection systems. Plant Science, Kidlington, v. 40, p. 209-219, 1985.

AGACHE, S.; BACHELIER, B.; DE BUYSER, J.; HENRY, Y.; SNAPE, J. Genetic analysis of anther culture response in wheat using aneuploid, chromosome substitution and translocation lines. Theoretical and Applied Genetics, Berlin, v. 77, p. 7-11, 1989.

ALONSO-BLANCO, C.; KOORNNEEF, M. Naturally occurring variation in Arabidopsis: an underexploited resource for plant genetics. Trends in Plant Science, Amsterdam, v. 5 , p. 22-29, 2000.

ARMSTRONG, C.L.; ROMERO-SEVERSON, J.; HODGES, T.K. Improved tissue culture response of an elite maize inbred through backcross breeding and identification of chromosomal regions important for regeneration by RFLP analysis. Theoretical and Applied Genetics, Berlin, v. 84, p. 755-762, 1992.

BAI, Y.; LINDHOUT, P. Domestication and breeding of tomatoes: what have we gained and what can we gain in the future? Annals Botany, London, v. 100, p. 1085-1094, 2007.

BISHOP, G.J.; NOMURA, T.; YOKOTA, T.; HARRISON, K.; NOGUCHI, T.; FUJIOKA, S.; TAKATSUTO, S.; JONES, J.D.G.; KAMIYA, Y. The tomato DWARF enzyme catalyses C- 6 oxidation in brassinosteroid biosynthesis. Proceedings of the National Academy of Sciences of the United States of America, Washington, v. 96, p. 17611766, 1999.

BOHOROVA, N.E.; COCKING, E.C.; POWER, J.B. Isolation, culture and callus regeneration of protoplasts of wild and cultivated Helianthus species. Plant Cell Reports, New York, v. 5, p. 256-258, 1986.

BOITEN, H.; AZMI, A.; DILLEN, W.; SCHEPPER, S.; DEBERGH, P.; GERATS, T.; ONCKELEN, H.; PRINSEN, E. The Rg-1 encoded regeneration capacity of tomato is not related to an altered cytokinin homeostasis. The New Phytologist, Lancaster, v. 161, p. 761-771, 2004.

CAMPOS, M.L.; CARVALHO, R.F.; BENEDITO, V.A.; PERES, L.E.P. Small and remarkable: the Micro-Tom model system as a tool to discover novel hormonal functions and interactions. Plant Signaling and Behavior, Sesto, v. 5, p. 50-54, 2010.

CAMPOS, M.L.; ALMEIDA, A.; ROSSI, M.L.; MARTINELLI, A.P.; JUNIOR, C.G.L.; FIGUEIRA, A.; FERREIRA, F.T.; VENDRAMIM, J.T.; BENEDITO, V.A.; PERES, L.E.P. Brassinosteroids interact negatively with jasmonates in the formation of anti-herbivory traits in tomato. Journal of Experimental Botany, Oxford, v. 60, p. 4347-4361, 2009. 
CARVALHO, R.F.; CAMPOS, M.L.; PINO, L.E.; CRESTANA, S.L.; ZSÖGÖN, A.; LIMA, J.E,; BENEDITO, V.A.; PERES, L.E.P. Convergence of developmental mutants into a single tomato model system: 'Micro-Tom' as an effective toolkit for plant development research. Plant Methods, London, v.7, p. 18, 2011.

CARY, A.J.; CHE, P.; HOWELL, S.H. Developmental events and shoot apical meristem gene expression patterns during shoot development in Arabidopsis thaliana. Plant Journal, Oxford, v. 32, p. 867-877, 2002.

CATTANEO, M.; QIAO, Y.M.; POGNA, N.E. Embryoid induction and green plant regeneration from cultured anthers in a durum wheat line homozygous for the 1BL/1RS translocation. Journal of Genetics and Breeding, Italy, n. 45, p. 369-372, 1991.

CATTEROU, M.; DUBOIS, F.; SMETS, R.; VANIET, S.; KICHEY, T.; VAN ONCKELEN, H.; SANGWAN-NORREEL, B.S.; SANGWAN, R.S. hoc: an Arabidopsis mutant overproducing cytokinins and expressing high in vitro organogenic capacity. Plant Journal. Oxford, v. 30, p. 273-287, 2002.

CHE, P.; LALL, S.; HOWELL, S.H. Developmental steps in acquiring competence for shoot development in Arabidopsis tissue culture. Planta, Berlin, v. 226, p. 1183-1194, 2007.

CHE, P.; LALL, S.; NETTLETON, D.; HOWELL, S.H. Gene expression programs during shoot, root, and callus development in Arabidopsis tissue culture. Plant Physiology, Collingwood, v. 141, p. 620-637, 2006.

CHRISTIANSON, M.L; WARNICK, D.A. Organogenesis in vitro as a developmental process. HortScience, Alexandria, v. 23, p. 515-519, 1988.

de FARIA, R.T.; DESTRO, D.; BESPALHOK, J.C.; ILLG, R.D. Introgression of in vitro regeneration capability of $L y$ copersicon pimpinellifolium Mill. into recalcitrant tomato cultivars. Euphytica, Wageningen, v. 124, p. 59-63, 2002.

DEVICENTE, M.C.; TANKSLEY, S.D. QTL analysis of transgressive segregation in an interspecific tomato cross. Genetics, Rockville, v. 134, p. 585-596, 1993.

DIRKS, R.; VAN DUN, K.; DE SNOO, C.B.; VAN DEN BERG, M.; LELIVELT, C.L.C.; VOERMANS, W.; WOUDENBERG, L.; DE WIT, J.P.C.; REININK, K.; SCHUT, J.W.; VAN DER ZEEUW, E.; VOGELAAR, A.; FREYMARK, G.; GUTTELING, E.W.; KEPPEL, M.N.; VAN DRONGELEN, P.; KIENY, M.; ELLUL, P.; TOURAEV, A.; MA, H,; DE JONG, H.; WIJNKER, E. Reverse breeding: a novel breeding approach based on engineered meiosis. Plant Biotechnology Journal, Hoboken, v. 7, p. 837-845, 2009. 
EMMANUEL, E.; LEVY, A.A. Tomato mutants as tools for functional genomics. Current Opinion on Plant Biology, Clayton, v. 5, p. 112-117, 2002.

ESCOLA SUPERIOR DE AGRICULTURA “LUIZ DE QUEIROZ". Disponível em: <http://www.esalq.usp.br/tomato/index.html>. Acesso em: 22 set. 2011.

ESHED, Y.; ZAMIR, D. A genomic library of Lycopersicon pennellii in L. esculentum: A tool for fine mapping of genes. Euphytica, Wageningen, v. 79, p. 175-179, 1994.

ESTRUCH, J.J.; PRINSEN, E.; VAN ONCKELEN, H.; SCHELL, J.; SPENA, A. Viviparous leaves produced by somatic activation of an inactive cytokinin-synthesizing gene. Science, Washington, v. 254, p. 1364-1367, 1991.

FELSENBURG, T.; FELDMAN, M.; GALUN E. Aneuploid and alloplasmic lines as tools for the study of nuclear and cytoplasmic control of culture ability and regeneration of scutellar calli from common wheat. Theoretical and Applied Genetics, Berlin, v. 74, p. 802-810, 1987.

FILLATI, J.J.; KISER, J.; ROSE, R.; COMAI, L. Efficient transfer of a glyphosate tolerance gene into tomato using a binary Agrobacterium tumefaciens vector. Biotechnology, Dickson, v. 5, p. 726-730, 1987.

FORSTER, B.P.; THOMAS, W.T.B. Doubled haploids in genetics and plant breeding. Plant Breeding Reviews, Philadelphia, v. 25, p. 57-88, 2005.

FOSKET, D.E. Plant growth and development. New York: Academic Press, 1994. $580 \mathrm{p}$.

FRANKENBERGER, E.A.; HASEGAWA, P.M.; TIGGHELAAR, E.C. Influence of environment and developmental state on the shoot-forming capacity of tomato genotypes. Zeitschrift für Pflanzenphysiologie, Berlin, v. 102, p. 221-232, 1981.

FRAY, R.; GRIERSON, D. Identification and genetic analysis of normal and mutant phytoene synthase genes of tomato by sequencing, complementation and cosuppression. Plant Molecular Biology, Dordrecht, v. 22, p. 589-602, 1993.

FULTON, T.M.; CHUNWONGSE, J.; TANKSLEY, S.D. Microprep protocol for extraction of DNA from tomato and herbaceous plants. Plant Molecular Biology Reporter, Ottawa, v. 13, n. 3, p.207-209, 1995.

GALIBA, G.; KOVÁCS, G.; SUTKA, J. Substitution analysis of plant regeneration from callus culture in wheat. Plant Breeding, New Jersey, v. 97, p. 261-263, 1986.

GALLOIS, J.L.; WOODWARD, C.; REDDY, G.V.; SABLOWSKI, R. Combined SHOOTR MERISTEM LESS and WUSCHEL, trigger ectopic organogenesis in Arabidopsis.

Development, Cambridge, v. 129, p. 3207-3217, 2002. 
GAMBORG, O.L.; MILLER, R.A.; OJIMA, K. Nutrient requirement of suspension cultures of soybean root cells. Experimental Cell Research, New York, v. 50, p. 151158, 1968.

GODT, D.E.; ROITSCH, T. Regulation and tissue-specific distribution of mRNAs for three extracellular invertase isoenzymes of tomato suggests an important function in establishing and maintaining sink metabolism. Plant Physiology, Collingwood, v. 115, p. 273-282, 1997.

GRATÃO, P.L.; MONTEIRO, C.C.; ANTUNES, A.M.; PERES, L.E.P.; AZEVEDO, R.A. Acquired tolerance of tomato (Lycopersicon esculentum cv. Micro-Tom) plants to cadmium-induced stress. Annals of Applied Biology, London, v. 153, p. 321-333, 2008.

GRIEVE, B. Studies in the physiology of host-parasite relations: adventitious root formation. Proceedings of the Royal Society of Victoria, Melbourne, v. 53, p. 323$341,1941$.

HAMZA, S.; CHUPEAU, Y. Re-evaluation of conditions for plant regeneration and Agrobacterium-mediated transformation from tomato (Lycopersicon esculentum). Journal of Experimental Botany, Oxford, v. 44, p. 1837-1845, 1993.

HENRY, Y.; DE BUYSER, J. Efffect of the 1B/1R translocation an anther culture ability in wheat (Triticum aestivum L.). Plant Cell Reports, New York, v. 4, p. 307-310, 1985.

HENRY, Y.; MARCOTTE, J.L.; DE BUYSER, J. Chromosomal location of genes controlling short-term and long-term somatic embryogenesis in wheat revealed by immature embryo culture of aneuploid lines. Theoretical and Applied Genetics, Berlin, v. 89 , p. 244-350, 1994b.

HENRY, Y.; VAIN, P.; DE BUYSER, J. Genetic analysis of in vitro plant tissue culture responses and regeneration capacities. Euphytica, Wageningen, v. 79, p. 45-58, 1994a.

HEUVELINK, E.; BUISKOOL, R.P.M. Infuence of sink-source interaction on dry matter production in tomato. Annals of Botany, London, v. 75, p. 381-389, 1995.

HIGGINS, P.; MATHIAS, R. J. The effect of the 4B chromosomes of hexaploid wheat on the growth and regeneration of callus cultures. Theoretical and Applied Genetics, Berlin, v. 89, p. 344-350, 1987.

HILLE, J.; KOORNNEEF, M.; RAMANNA, M.S.; ZABEL, P. Tomato: a crop species amenable to improvement by cellular and molecular methods. Euphytica, Wageningen, v. 42, n. 1/2, p. 1-23, Sept. 1989. 
HONG, S.J.; LEE, S.K. Changes in endogenous plant hormones during ripening of tomato fruits. Acta Horticulturae, Leuven, n. 343, p. 220-224, 1993.

HU, Q.; ANDERSEN, S.B.; HANSEN, L.N. Plant regeneration capacity of mesophyll protoplasts from Brassica napus and related species. Plant Cell, Tissue and Organ Culture, Dordrecht, v. 59, p. 189-196, 1999.

KALEIKAU, E.K.; SEARS, R.G.; GILL, B.S. Monosomic analysis of tissue culture response in wheat (Triticum aestivum L.). Theoretical and Applied Genetics, Berlin, v. 78, p. 625-632, 1989.

KAUFFMAN, J.B. Survival by sprouting following fire in tropical forests of the Eastern Amazon. Biotropica, France, v. 23, p. 219-224, 1991.

KOORNNEEF, M.; ALONSOBLANCO, C.; PEETERS, A.J.M. Genetic approaches in plant physiology. New Phytology, Cambridge, v. 137, p. 1-8, 1997.

KOORNNEEF, M.; HANHART, C.J.; MARTINELLI, L. Genetic analysis of cell culture traits in tomato. Theoretical and Applied Genetics, Berlin, v. 74, p. 633-641, 1987.

KOORNNEEF, M.; BADE, J.; HANHART, C.; HORSMAN, K.; SCHEL, J.; SOPPE, W.; VERKERK, R.; ZABEL, P. Characterization and mapping of a gene controlling shoot regeneration in tomato. Plant Journal, Oxford, v. 3, p. 131-141, 1993.

KUT, S.A.; EVANS, D.A. Plant regeneration from cultured leaf explants of eight wild tomato species and two related Solanum species. In Vitro Cellular and

Developmental Biology, Gaithersburg, v. 8, p. 593-598, 1982.

LANGRIDGE, P.; LAZZERI, P.; LÖRZ, H. A segment of rye chromosome 1 enhances growth and embryogenesis of calli derived from immature embryos of wheat. Plant Cell Reports, New York, v. 10, p. 148-151, 1991.

LI, W.; CHETELAT, R.T. A pollen factor linking inter- and intraspecific pollen rejection in tomato. Science, Washington, v. 330, p. 1827-1830, 2010.

LIMA, J.E.; BENEDITO, V.A.; FIGUEIRA, A.; PERES, L.E. Callus, shoot and hairy root formation in vitro as affected by the sensitivity to auxin and ethylene in tomato mutants. Plant Cell Reports, New York, v. 28, p. 1169-1177, 2009.

LIMA, J.E.; CARVALHO, R.F.; TULMANN NETO, A.; FIGUEIRA, A.; PERES, L.E.P. Micro-MsK: a tomato genotype with miniature size, short life cycle and improved in vitro shoot regeneration. Plant Science, Kidlington, v. 167, p. 753-757, 2004.

LIPUCCI DI PAOLA, M.; COLLINA, G.F.; SCALA, A. Shoot forming ability of Lycopersicon esculentum Mill. Varieties by in vitro cultured cotyledons. Acta Horticulturae, Ghent, n. 131, p. 111-116, 1983. 
LIU, Y-S.; ZAMIR, D. Second-generation L. pennellii introgression lines and the concept of bin mapping. Tomato Genetics Cooperative, Bradenton, n. 49, p. 26-30, 1999.

LIU, Y-S.; GUR, A.; RONEN, G.; CAUSSE, M.; DAMIDAUX, R.; BURET, M.; HIRSCHBERG, J.; ZAMIR, D. There is more to tomato fruit colour than candidate carotenoid genes. Plant Biotechnology Journal, Hoboken, v. 1, p. 195-207, 2003.

LUCKETT, D.J.; VENKATANAGAPPA, S.; DARVEY, N.L.; SMITHARD, R.A. Another culture of Australian wheat germplasm using modified $\mathrm{C} 17$ medium and membrane rafts. Journal of Plant Physiology, Melbourne, v. 18, p. 357-367, 1991.

MANO, Y.; TAKAHASHI, H.; SATO, K.; TAKEDA, K. Mapping genes for callus growth and shoot regeneration in barley (Hordeum vulgare L.). Breeding Science, Tokyo, v. 46, p. 137-142, 1996.

MANO, Y.; MURAKI, M.; FUJIMORI, M.; TAKAMIZO, T.; KINDIGER, B. Identification of QTL controlling adventitious root formation during flooding conditions in teosinte (Zea mays ssp huehuetenangensis) seedlings. Euphytica, Wageningen, v. 142, p. 33-42, 2005.

MARTI, E.; GISBERT, C.; BISHOP, G.J.; DIXON, M.S.; GARCIAMARTINEZ, J.L. Genetic and physiological characterization of tomato cv. Micro-Tom. Journal of Experimental Botany, Oxford, v. 57, p. 2037-2047, 2006.

MATHIAS, R.J.; FUKUI, K. The effect of specific chromosome and cytoplasm substitutions on the tissue culture response of wheat (Triticum aestivum) callus. Theoretical and Applied Genetics, Berlin, v. 71, p. 797-800, 1986.

MEISSNER, R.; JACOBSON, Y.; MELAMED, S.; LEVYYATUY, S.; SHALEV, G.; ASHRI, A.; ELKIND, Y. A new model system for tomato genetics. Plant Journal, Oxford, v. 12, p. 1465-1472, 1997.

MOREIRA-DIAS, J.M.; MOLINA, R.V.; GUARDIOLA, J.L.; GARCÍALUIS, A. Daylength and photon flux density influence the growth regulator effects on morphogenesis in epicotyl segments of Troyer citrange. Scientia Horticulturae, Amsterdam, v. 87, p. 275-290, 2001.

MORGAN, A.; COCKING, E.C. Plant regeneration from protoplasts of Lycopersicon esculentum Mill. Zeitschrift für Pflanzenphysiologie, Berlin, v. 106, p. 97-104, 1982.

MURASHIGUE, T.; SKOOG, F.A. A revised medium for rapid growth and bioassays with tobacco tissue cultures. Physiologia Plantarum, Hoboken, v. 15, p. 473-497, 1962. 
MŸLLER, G.; BÖHME, T.; BORSCHEL, H.; VAHL, U.; WIBERG, A. Die Nutzung der Antherenkulturmethode im Zuchproze $\beta$ von Winterweizen. III. Zur

Antherenkultureignung von Winterweizen-F1-Populationen mit den beiden heterozygoten Chromosomenpaaren $1 \mathrm{AL}-1 \mathrm{AS} / 1 \mathrm{AL}-1 \mathrm{RS}$. Plant Breeding, New Jersey, v. 104, p. 272-280, 1990.

MŸLLER, G.; BORSCHEL, H.; VAHL, U.; WIBERG, A.; HÄRTEL, H.; DAMISCH, W. Die Nutzung der Antherenkulturmethode im Zuchproze $\beta$ von Winterweizen. I. Zur Andorgenesefähigkeit von 1B-1R-Weizen-Roggen- Translokationsformen. Plant Breeding, New Jersey, n. 102, p. 196-207, 1989.

NORTON, J.P.; BOLL, W.G. Callus and shoot formation from tomato roots in vitro. Science, Washington, v. 119, p. 220-221, 1954.

OCHOA, I.E.; BLAIR, M.W.; LYNCH, J.P. QTL analysis of adventitious root formation in common bean under contrasting phosphorus availability. Crop Science, Madison, v. 46, p. 1609-1621, 2006.

OHKI, S.; BIGOT, C.; MOUSSEAU, J. Analysis of shoot forming capacity in vitro in two lines of tomato (Lycopersicon esculentum Mill) and their hybrids. Plant and Cell Physiology, Kyoto, v. 19, p. 27-42, 1978.

PARAN, I.; ZAMIR, D. Quantitative traits in plants: beyond the QTL. Trends in Genetics, Amsterdam, v. 19, p. 303-306, 2003.

PATIL, R.S. Genetic manipulation of tomato (Lycopersicon esculentum Mill.) for crop improvement. 1994. 253 p. Thesis (Ph.D. in Botany) - University of Nottingham, Nottingham, 1994.

PERES, L.E.P. Bases fisiológicas e genéticas da regeneração de plantas in vitro. Revista Biotecnologia Ciência \& Desenvolvimento, Brasília, v. 4, n. 25, p. 44-48, 2002.

PERES, L.E.P.; KERBAUY, G.B. High cytokinin accumulation following root tip excision changes the endogenous auxin to cytokinin ratio during root-to-shoot conversion in Catasetum fimbriatum Lindl. (Orchidaceae). Plant Cell Reports, New York, v. 18, p. 1002-1006, 1999.

PERES, L.E.P.; MORGANTE, P.G.; VECHI, C.; KRAUS, J.E.; VAN SLUYS, M.A. Shoot regeneration capacity from roots and transgenic hairy roots of different tomato cultivars and wild related species. Plant Cell, Tissue and Organ Culture, Dordrecht, v. 65, p. 37-44, 2001. 
PINO, L.E.; LOMBARDI-CRESTANA, S.; AZEVEDO, M.S.; SCOTTON, D.C.; BORGO, L.; QUECINI, V.; FIGUEIRA, A.; PERES, L.E.P. The Rg1 allele as a valuable tool for genetic transformation of the tomato Micro-Tom model system. Plant Methods, London, v. 6, p. 23, 2010.

PINO-NUNES, L.E.; ZSÖGÖN, A.; PIOTTO, F.A.; SILVA, J.A.; BERNARDI, W.F.; FIGUEIRA, A.; TULMANN NETO, A.; PERES, L.E.P. Induced mutagenesis and natural genetic variation in tomato 'Micro-Tom'. Acta Horticulturae, Ghent, n. 821, p. 63-72, 2009.

PNUELI, L.; CARMEL-GOREN, L.; HAREVEN, D.; GUTFINGER, T.; ALVAREZ, J.; GANAL, M.; ZAMIR, D.; LIFSCHITZ, E. The SELF-PRUNING gene of tomato regulates vegetative to reproductive switching of sympodial meristems and the ortholog of CEN and TFL1. Development, Cambridge, v. 125, p. 1979-1989, 1998.

RICK, C.M.; YODER, J.I. Classical and molecular genetics of tomato: highlights and perspectives. Annual Review of Genetics, Palo Alto, v. 22, p. 281-300, 1988.

SATOH, H.; TAKASHINA, T.; ESCALANTE, A.; EGASHIRA, H.; IMANISHI, S. Molecular markers mapped around the high shoot regeneration capacity gene $R g-2$ in Lycopersicon chilense. Breeding Science, Tsukuba, v. 50, p. 251-256, 2000.

SCOTT, J.; HARBAUGH, B. Micro-Tom: a miniature dwarf tomato. Florida Agricultural Experiment Stations, Gainesville, n. 370, p. 1-6, 1989.

SEGUÍ-SIMARRO, J.M.; CORRAL-MARTÍNEZ, P.; PARRA-VEJA, V.; GONZÁLEZGARCÍA, B. Androgenesis in recalcitrant solanaceous crops. Plant Cell Reports, New York, v. 30, p. 765-778, 2011.

SKOOG, F.; MILLER, C.O. Chemical regulation of growth and organ formation in plant tissues cultured in vitro. Symposia of the Society for Experimental Biology, Arizona, v. 11, p. $118-131,1957$.

SOL GENOMICS NETWORK. Disponível em: <http://solgenomics.net/about/tomato_project_overview.pl>. Acesso em: 17 out. 2011.

STEVENS, M.A.; RICK, C.M. Genetic and breeding. In: ATHERTON, J.G.; RUDICH, J. (Ed.). The tomato crop: a scientific basis for improvement. London: Chapman and Hall, 1986. n. 35, p. 109.

STOMMEL, J.R.; SINDEN, S.L. Genotypic differences in shoot forming capacity of cultured leaf explants of Lycopersicon hirsutum. HortScience, Alexandria, v. 26, p. 1317-1320, 1991. 
SUGIMOTO, K.; GORDON, S.P.; MEYEROWITZ, E.M. Regeneration in plants and animals: dedifferentiation, transdifferentiation, or just differentiation? Trends in Cell Biology, Amsterdam, v. 21, p. 212-218, 2011.

SUGIMOTO, K.; JIAO, Y.; MEYEROWITZ, E.M. Arabidopsis regeneration from multiple tissues occurs via a root development pathway. Developmental Cell, Massachusetts, v. 18, p. 463-471, 2010.

SUGIYAMA, M. Genetic analysis of plant morphogenesis in vitro. International Review of Cytology, New York, v. 196, p. 67-84, 2000.

SZAKÁCS, É.; KOVÁCS, G.; PAUK, J.; BARNABÁS, B. Substitution analysis of callus induction and plant regeneration from anther culture in wheat (Triticum aestivum $L$.). Plant Cell Reports, New York, v. 7, p. 127-129, 1988.

TAGUCHI-SHIOBARA, F.; LIN, S.Y.; TANNO, K.; KOMATSUDA, T.; YANO, M.; SASAKI, T.; OKA, S. Mapping quantitative loci associated with regeneration ability of seed callus in rice, Oryza sativa L. Theoretical and Applied Genetics, Berlin, v. 95, p. 828-833, 1997.

TAN, M.M.C.; COLIJN-HOOYMANS, C.M.; LINDHOUT, W.H.; KOOL, A.J. A comparison of shoot regeneration from protoplasts and leaf discs of different genotypes of the cultivated tomato. Theoretical and Applied Genetics, Berlin, v. 75, p. 79-84, 1987.

TANKSLEY, S.D.; GANAL, M.W.; PRINCE, J.P.; DE VINCENTE, M.C.; BONIERBALE, M.W., BROUN, P.; FULTON, F.M.; GIOVANNONI, J.J.; GRANDILLO, S.; MARTIN, G.B.; MESSEGUER, R.; MILLER, J.C.; MILLER, L.; PATERSON, A.H.; PINEDA, O.; RODER, M.S.; WING, R.A.; WU, W.; YOUNG, N.D. High density molecular linkage maps of the tomato and potato genomes. Genetics, Rockville, v. 132, p. 1141-1160, 1992.

THE L. PENNELLII INTROGRESSION LINES (ILS). Disponível em <http://zamir.sgn.cornell.edu/Qtl/il_story.htm>. Acesso em: 01jun. 2111.

THORPE, T.A. Morphogenesis and regeneration. In: VASIL, I.K.; THORPE, T.A. (Ed.). Plant cell and tissue culture. Dordrecht: Kluwer Academic, 1994. v. 2, p. 17-36.

TRAN THANH VAN, M. Direct flower neoformation from superficial tissue of small explants of Nicotiana tabacum L. Planta, Berlin, v. 115, p. 87-92, 1973.

VALVEKENS, D.; VAN MONTAGU, M.; LIJSEBETTENS, M. Agrobacterium tumefaciens-mediated transformation of Arabdopsis thaliana root explants by using kanamycin selection. Proceedings of the National Academy of Sciences of the United States of America, Washington, v. 85, p. 5536-5540, 1988. 
van der MEIJDEN, E.; WIJN, M.; VERKAAR, H.J. Defense and regrowth, alternative plant strategies in the struggle against herbivores. Oikos, Lund, v. 51, p. 355-363, 1988.

VASIL, I.K. A history of plant biotechnology: from the Cell Theory of Schleiden and Schwann to biotech crops. Plant Cell Reports, New York, v. 27, p. 1423-1440, 2008.

WIJBRANDI, J.; VOS, J.G.M.; KOORNNEEF, M. Transfer of regeneration capacity from Lycopersicon peruvianum to L.esculentum by protoplast fusion. Plant Cell Tissue Culture, Amsterdam, v. 12, p. 193-196, 1988.

YEAGER, T. The uniform fruit color gene in the tomato. Proceedings of the American Society for Horticultural Science, Alexandria, v. 33, p. 512, 1935. 
ANEXOS 


\title{
ANEXO A
}

\section{Solanum pennellii LA716 as a source of genes improving in vitro organogenesis in cultivate tomato}

\author{
F.N. Arikita, M.S. Azevedo, L.E.P. D.C. Scotton, A. Figueira \\ Peres \\ Escola Superior de Agricultura \\ 'Luiz de Queiroz' \\ Universidade de São Paulo \\ Brazil
Centro de Energia Nuclear na
Agricultura Universidade de São Paulo
Brazil

Keywords: biotechnology, introgression lines, natural genetic variation, regeneration,

\begin{abstract}
In the present work we are reporting the high in vitro regeneration capacity of the tomato related wild species S. pennellii LA716, which enabled us to used a collection of 50 introgression lines (ILs), each containing small chromosomal segments of LA716 introgressed and mapped into the cultivar M82. We found a high shoot regeneration capacity for IL3-2, IL6-1, IL7-1 (7-2, 7-3), IL 8-3 (8-2), IL-9-1 (9-2) and IL10-2 (10-3), when 12-days-old cotyledon explants were cultivated in MS medium containing 5.0 $\mu \mathrm{M}$ BAP. This means that $S$. pennellii probably presents superior alleles for in vitro regeneration in such chromosomal segments. Since ILs 3-2, 7-1, 8-3, and 10-2 also presented enhanced root formation in MS medium containing $0.4 \mu \mathrm{M}$ NAA, they may represent novel alleles controlling the competence to assume different cell fates, rather than the induction of a specific organ. The alleles discovered here will provide for the characterization and isolation of important genes for plant development studies and biotechnological applications.
\end{abstract}

\section{NTRODUCTION}

Despite the wide use of adventitious organ formation for biotechnological proposes, the genetic basis of this capacity remains largely unknown. Tomato (Solanum lycopersicum L.) presents many characteristics of a suitable genetic model: it is an autogamous diploid species with a small genome (950 Mb) distributed in 12 chromosomes, and it has a saturated genetic linkage map (http://solgenomics.net/) with numerous markers associated with traits of great economic and biological importance, as well as, a plethora of well characterized mutants (http://tgrc.ucdavis.edu/). Besides induced mutations, natural genetic variation can be found in the wild Solanum species 
section Lycopersicon, most of which are inter-fertile and amenable for crossing with cultivated tomato (Stevens and Rick, 1986). The observation of new phenotypes and identification of novel alleles coming from wild species is facilitated by the use of introgression lines (ILs), which are permanent mapping resource populations (Eshed and Zamir, 1994). Once identified, the specific effect of a given natural genetic variation can be efficiently studied by constructing nearly isogenic lines (NILs) that differ only at a single quantitative trait loci (QTL) region or mendelian gene (Paran and Zamir, 2003).

Tomato has been proved to be an excellent model for the study of natural genetic variations controlling the in vitro regeneration capacity. Among the wild tomato related species, $S$. peruvianum and its sibling $S$. chilense are considered highly organogenetic (Koornneef et al., 1987; Peres et al., 2001). Studying the genetic basis of organogenetic competence in S. peruvianum, Koornneef et al. (1987) found that this character was associated with two major dominant alleles (named $R g 1$ and $R g 2$ ). The $R g 1$ was further mapped to chromosome 3, close to the yellow fresh (r) locus (Koornneef et al., 1993). The recessive $r$ allele represents a loss of function in the chromoplast-specific phytoene synthase (PSY) gene (Fray and Grierson, 1993), conferring yellow color to fruits when introgressed into the S. lycopersicum background (Koornneef et al., 1993). It was suggested that other green fruited species harboring the $r$ allele may also have versions of the Rg1 allele conferring high organogenetic capacity (Peres et al., 2001). The presence of the $r$ allele in the green fruited species $S$. peruvianum creates the opportunity to use it as a morphological marker for the introgression of $R g 1$ into cultivated tomato. Using this procedure, the $R g 1$ allele from $S$. peruvianum was further transferred to the cv MT (Lima et al., 2004), creating a genotype that is been put forward as a tool for genetic transformation of MT model system (Pino et al., 2010).

In the present work we are reporting the high in vitro regeneration capacity of the green fruited species $S$. pennellii LA716, which enabled us to used a collection of 50 ILs, each containing small chromosomal segments of $S$. pennellii LA716 introgressed and mapped into the cultivar M82, to search for natural genetic variation controlling in vitro organ formation capacity.

\section{MATERIALS END METHODS}

The tomato (Solanum lycopersicum L.) cv M82, the wild species $S$. pennellii LA716, and the collection of 50 introgression lines (ILs) derived from the cross cv M82 $x$ LA716 (Eshed and Zamir, 1994) were provided by Dr. Roger Chetelat at The C. M. Rick Tomato Genetics Resource Center (http://tgrc.ucdavis.edu/). Seeds from M82, LA716 and the introgression lines (ILs) were surface-sterilized by shaking in $100 \mathrm{~mL}$ of $30 \%$ $(\mathrm{v} / \mathrm{v})$ commercial bleach $(2.7 \%$ sodium hypochloride) plus two drops of commercial detergent, for $15 \mathrm{~min}$, followed by three rinses with sterile water. The seeds were then germinated on half strength MS salts; half strength B5 vitamins; $15 \mathrm{~g} \mathrm{~L}^{-1}$ sucrose and 6 $\mathrm{g} \mathrm{L}^{-1}$ agar (Merck, Darmstadt, Germany). The medium $\mathrm{pH}$ was adjusted to 5.8 before autoclaving. Approximately 40 seeds were sown per flask containing $30 \mathrm{~mL}$ of medium. Cultures were sealed with PVC and incubated at $25 \pm 1{ }^{\circ} \mathrm{C}$ in the dark for $4 \mathrm{~d}$, followed by $8 \mathrm{~d}$ under 16 -h photoperiod provided by a $40 \mathrm{~W}$ cool white fluorescent tube (c.a. 45 $\mu \mathrm{mol}$ PAR $\mathrm{m}^{-2} \mathrm{~s}^{-1}$ ). Cotyledons were isolated from 12-day-old seedlings. The distal and proximal tips were removed, and the cotyledons were divided transversally in two or 
three pieces. Explants were placed with the abaxial side down immediately after isolation, with 15 explants per Petri dish $(90 \times 15 \mathrm{~mm})$, using 6 plates per treatment. Explants were placed onto semi solid Shoot Inducing Medium (SIM), composed by MS salts with B5 vitamins, $30 \mathrm{~g} \mathrm{~L}^{-1}$ sucrose, $6 \mathrm{~g} \mathrm{~L}^{-1}$ agar, 5 HM BAP (Sigma, St Louis, USA), or Root Inducer Medium (RIM), which has the same composition of SIM, except for the replacement of BAP with $0.4 \mu \mathrm{M}$ NAA (Sigma, St Louis, USA). Plates were sealed with PVC and maintained under $16 \mathrm{~h}$ photoperiod at $25 \pm 1^{\circ} \mathrm{C}$ for 3 weeks.

\section{RESULTS}

Taking into account that some tomato related green fruit wild species are high regenerating in vitro (Koornneef et al., 1987; Peres et al., 2001), in the present work we tested such capacity for $S$. pennellii, a green fruited species. The improved in vitro shoot formation capacity of $S$. pennellii is evident when compared to the cultivar M82 in 12days old cotyledons explants cultivated in $5.0 \mu \mathrm{M}$ BAP (Fig. 1). We were able to observe a considerable variation in the capacity to form shoot in cotyledon explants cultured in vitro in a population of ILs harboring small segments of $S$. pennellii introgressed into the cv M82 (Fig. 1A). Among the genotypes observed, the ILs 2-1, 3-1, 6-3 and 7-5 presented the lowest formation of shoots in vitro (Fig. 1A). Such ILs may represent loci where $S$. pennellii alleles are inferior to that of M82 for regeneration capacity. These transgressive phenotypes maybe the product of epistatic interactions into the M82 background, or the effect of $S$. pennellii alleles per se (DeVicente and Tanksley, 1993). On the other hand, the ILs 3-2, 6-1, 7-1 (and 7-2), 8-3 (and 8-2), 9-1 (and 9-2) and 10-2 (and 10-3) are likely representing superior alleles present in $S$. pennellii controlling the capacity to form shoots in vitro. Using the concept of bin mapping created for this same population of ILs (Liu et al., 2003), it was possible to classify the chromosomal regions most probable to harbor the alleles for high shoot formation capacity into bins $3 \mathrm{C}, 6 \mathrm{~A}, 7 \mathrm{H}, 8 \mathrm{~F}, 9 \mathrm{DE}$ and $10 \mathrm{~F}$ (Fig. 2).

In independent experiments, we had confirmed the high frequency of explants forming shoots in ILs 3-2, 6-1, 7-1, 8-3, 9-1 and 10-2, which presented a regeneration capacity not statistically different from that of the high regenerating parental S. pennellii (Fig. 3A). We further tested the capacity of the select ILs to form roots in RIM (0.4 $\mu \mathrm{M}$ NAA). The high root formation capacity of ILs 3-2, 8-3, 10-2 and, in a minor extend, of 7-1 (Fig. 3B), indicates that the alleles presented in these ILs are controlling the formation of both shoot and roots. On the other hand, the ILs 6-1 and 9-1 seems to be specifically improving shoot formation (Fig. 3A), but not root formation (Fig. 3B).

\section{DISCUSSION}

In the present work we identified six chromosomal segments whose alleles from the tomato relative wild species $S$. pennellii improve organogenesis in vitro. These QTL (Paran and Zamir, 2003) for in vitro regeneration capacity, were named, after Liu et al., (2003), as RG3C, RG6A, RG7H, RG8F, RG9DE and RG10F. Studying the genetic 
basis of in vitro high organogenetic capacity in S. peruvianum, Koornneef et al., (1987) found that this character was associated with two major dominant alleles (named $R g 1$ and Rg2). The Rg1 was further mapped to chromosome 3, close to the yellow fresh (r) locus (Koornneef et al., 1993). The RG3C described here is likely to be the $S$. pennellii equivalent to the $R g 1$ from $S$. peruvianum, since they, and the $r$ locus, all map in the same bin 3C (Fig. 2, Koornneef et al., 1993). It might be also that some one of the other loci described here corresponds to the Rg2 (Koornneef et al., 1987), although we do not have information about the map position of $R g 2$ for comparison.

The loci RG3C, RG7H, RG8F and RG10F described here as controlling high in vitro shoot formation capacity also enhanced root formation in adequate medium. The other two loci, RG6A and RG9DE, seem to be specific for shoot formation capacity. Christianson and Warnick (1988) divided the process of organogenesis in vitro in the following steps: 1) dedifferentiation, 2) acquisition of competence, 3) induction, 4) determination; 5) differentiation and 6) formation of the organ. In this division, the step of acquisition of competence is a general process necessary for both shoot and root formation, whereas the induction requires specific auxin-to-cytokinin balances leading to shoot or root formation (Skoog and Miller, 1957), but not both organs. Based on this concept, it is proposed that $R G 3 C, R G 7 H, R G 8 F$ and $R G 10 F$ are probably affecting the step of acquisition of competence and that RG6A and RG9DE are affecting the step of shoot induction.

Regardless the genetic identity of the loci described here, the usefulness of genes improving in vitro regeneration capacity is evident not only for tomato but for most crop species. Although Agrobacterium mediated plant transformation has long been established for tomato (Fillati et al., 1987), this procedure are been continuously improved, with key contribution of alleles enhancing in vitro regeneration (Pino et al., 2010). Moreover, until present date, the important breeding tool of double haploid production (Forster and Thomas, 2005), and thus reverse breeding (Dirks et al., 2009), is not available in tomato. The main barrier for haploid production in tomato stands in the low regeneration of anthers when cultured in different media (Seguí-Simarro et al., 2011). Since some of the alleles described here are likely to be controlling the capacity to assume different cell fates (competence), they may be useful to improve different regeneration systems.

\section{ACKNOWLEDGMENTS}

To FAPESP (Grant num.: 07/07175-0) for financial support. To CNPq (A. F. and L.E.P.P.), CAPES (F. N. A. and D. C. S.) and FAPESP (M. S. A.) for the fellowships and scholarships granted.

\section{Literature Cited}

Christianson, M.L; Warnick, D.A. 1988. Organogenesis in vitro as a developmental process. HortScience 23:515-519. 
DeVicente, M.C.; Tanksley, S.D. 1993. QTL analysis of transgressive segregation in an interspecific tomato cross. Genetics 134 585-596.

Dirks, R.; van Dun, K.; de Snoo, C.B.; van den Berg, M.; Lelivelt, C.L.C.; Voermans, W.; Woudenberg, L.; de Wit, J.P.C.; Reinink, K.; Schut, J.W.; van der Zeeuw, E.; Vogelaar, A.; Freymark, G.; Gutteling, E.W.; Keppel, M.N.; van Drongelen, P.; Kieny, M.; Ellul, .; Touraev, A.; Ma, H.; de Jong, H.; Wijnker, E. 2009. Reverse breeding: a novel breeding approach based on engineered meiosis. Plant Biotechnology Journal 7:837-845.

Eshed, Y.; zamir, D. 1994. A genomic library of Lycopersicon pennellii in L. esculentum: A tool for fine mapping of genes. Euphytica 79:175-179.

Fillati, J.J.; Kiser, J.; Rose, R.; Comai, L. 1987. Efficient transfer of a glyphosate tolerance gene into tomato using a binary Agrobacterium tumefaciens vector. Biotechnology 5:726-730.

Forster, B.P.; Thomas, W.T.B. 2005. Doubled haploids in genetics and plant breeding. Plant Breeding Reviews 25:57-88.

Fray, R.; Grierson, D. 1993. Identification and genetic analysis of normal and mutant phytoene synthase genes of tomato by sequencing, complementation and cosuppression. Plant. Mol. Biol. 22:589-602.

Koornneef, M., Bade, J., Hanhart, C., Horsman, K., Schel, J., Soppe, W., Verkerk, R., Zabel, P. 1993. Characterization and mapping of a gene controlling shoot regeneration in tomato. Plant Journal 3:131-141.

Koornneef, M.; Hanhart, C.J.; Martinelli, L. 1987. Genetic analysis of cell culture traits in tomato. Theorectical and Applied Genetics 74:633-641.

Lima, J.E.; Carvalho, R.F.; Tulmann Neto, A.; Figueira, A.; Peres, L.E.P. 2004. MicroMsK: a tomato genotype with miniature size, short life cycle and improved in vitro shoot regeneration. Plant Science 167:753 -757.

Liu, Y-S.; Gur, A.; Ronen, G.; Causse, M.; Damidaux, R.; Buret, M.; Hirschberg, J.; Zamir, D. 2003. There is more to tomato fruit colour than candidate carotenoid genes. Plant Biotechnology Journal 1:195-207.

Paran, I.; Zamir, D. 2003. Quantitative traits in plants: beyond the QTL. Trends in Genetics 19:303-306.

Peres, L.E.P.; Morgante, P.G.; Vechi, C.; Kraus, J.E.; Van Sluys, M.A. 2001. Shoot regeneration capacity from roots and transgenic hairy roots of different tomato cultivars and wild related species. Plant Cell, Tissue and Organ Culture 65:37-44. 
Pino, L.E.; Lombardi-Crestana, S.; Azevedo, M.S.; Scotton, D.C.; Borgo, L.; Quecini, V.; Figueira, A.; Peres, L.E.P. 2010. The Rg1 allele as a valuable tool for genetic transformation of the tomato Micro-Tom model system. Plant Methods 6:23.

Seguí-Simarro, J.M.; Corral-Martínez, P.; Parra-Veja, V.; González-García, B. 2011. Androgenesis in recalcitrant solanaceous crops. Plant Cell Rep 30:765-778.

Skoog, F.; Miller, C.O. 1957. Chemical regulation of growth and organ formation in plant tissues cultured in vitro. Symp Soc Exp Biol. Arizona 11:118-131.

Stevens, M.A.; Rick, C.M. 1986. Genetic and breeding. p. 35:109. In: Atherton, J.G.; Rudich, J. (eds.), The tomato crop: a scientific basis for improvement, London, Chapman and Hall. 


\section{Figures}

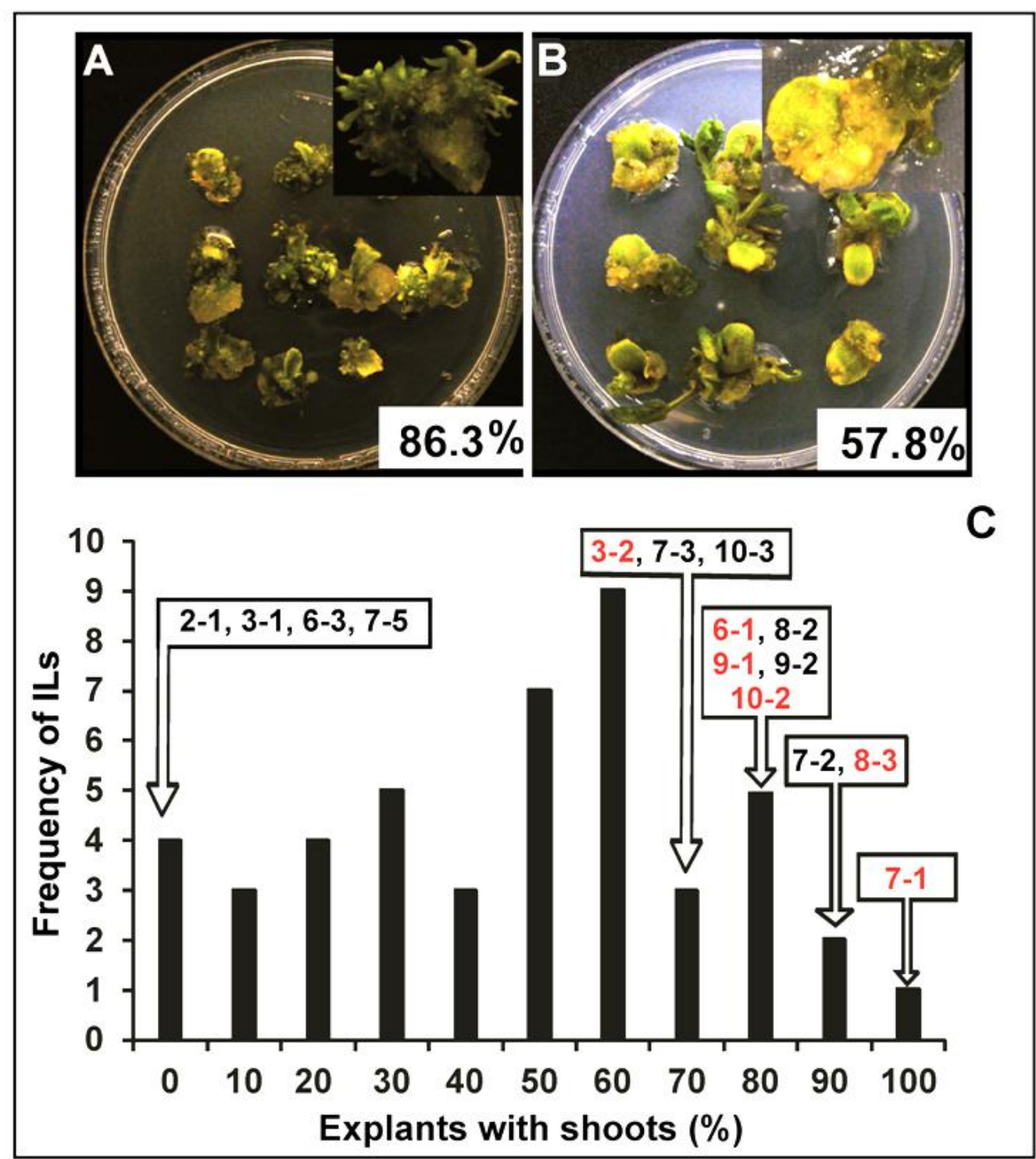

Fig. 1. Tomato chromosomal regions controlling in vitro shoot formation. (A) Distribution of the shoot regeneration capacity of tomato introgression lines (IL) representing small chromosomal segments of the wild species S. pennellii LA716 (B) introgressed into the cv M82 (C). In A, the numbers in boxes represent IL identification denoted by the chromosome and the segment, respectively. In B-C the inserted numbers represent the $\%$ of explants forming shoots. 12-days-old (from sowing) cotyledon explants were cultivated in MS medium plus 5.0 $\mu \mathrm{M}$ BAP for 21 days. 

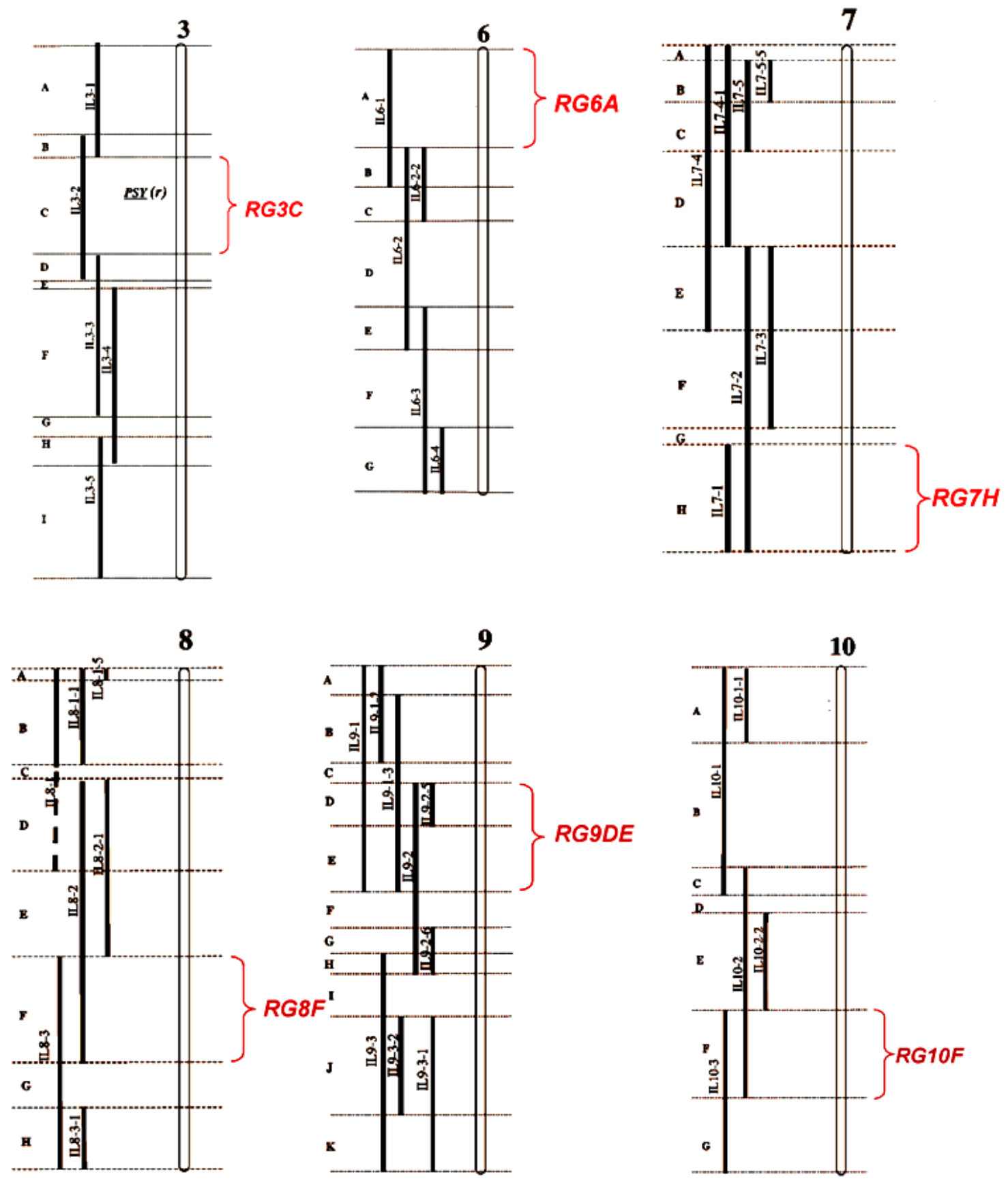

Fig. 2. Bin mapping (after Liu et al., 2003) of chromosomal segments improving shoot formation in vitro. The phytoene synthase (PSY) gene is depicted in the bin C of chromosome 3. 


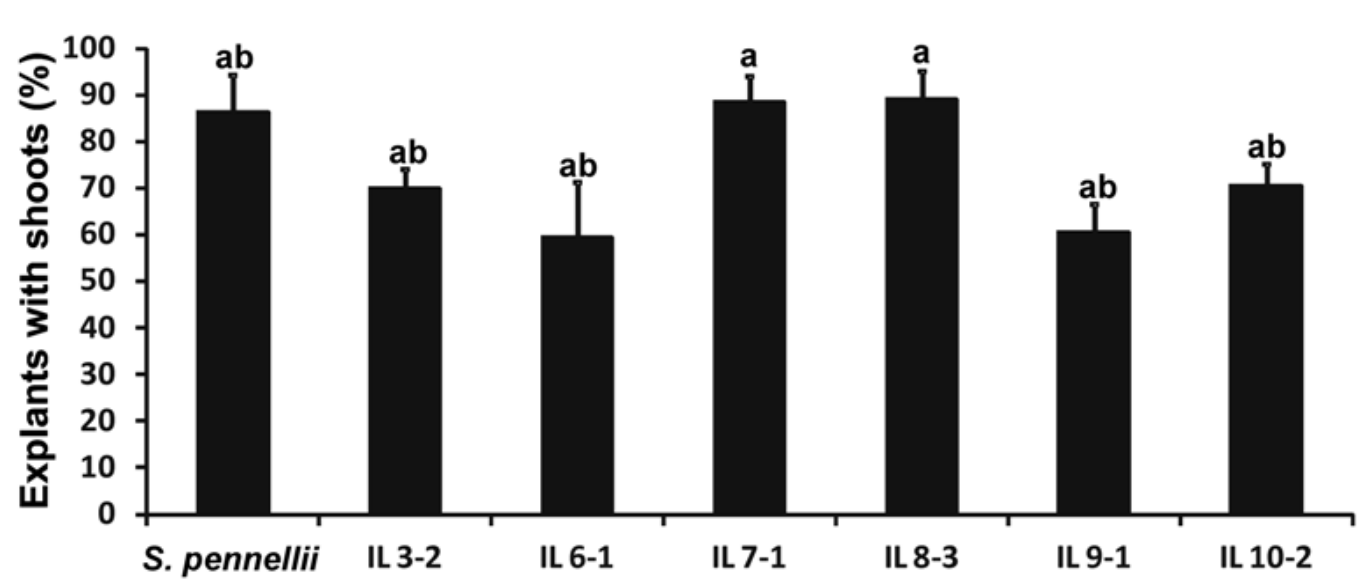

A

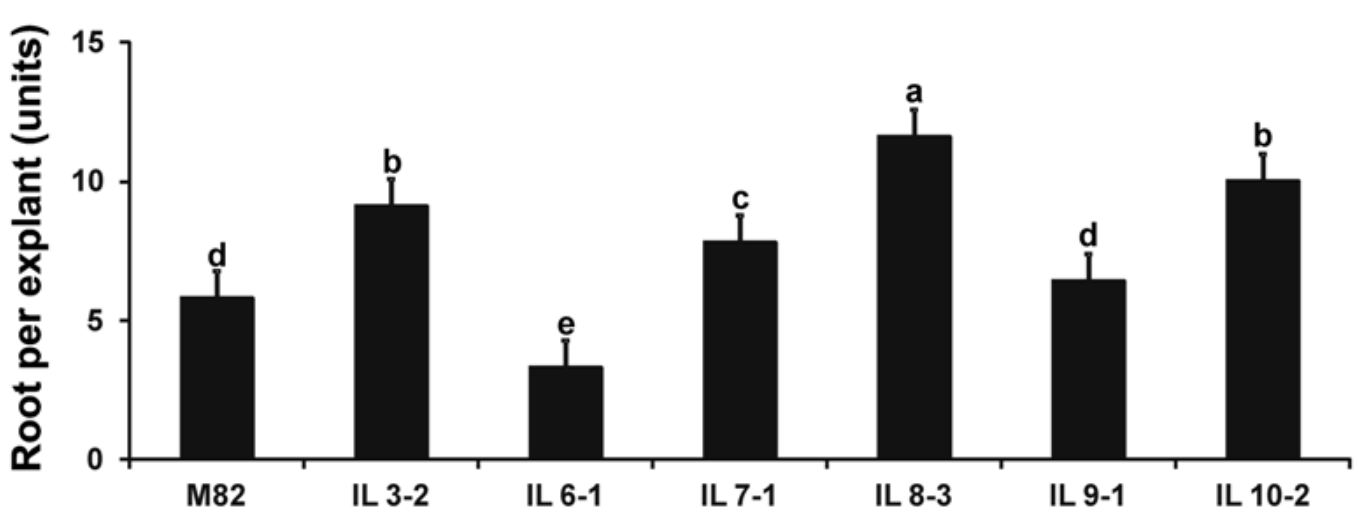

Genotypes

Fig. 3. Shoot and root regeneration capacity of selected introgression lines (ILs). (A) Shoot formation in cotyledonary explants from $S$. pennellii LA716 and selected ILS cultivated in SIM. (B) Root formation in cotyledonary explants from cv M82 and selected ILs cultivate in RIM. 12-days-old cotyledon explants were cultivated in MS medium plus $5.0 \mu \mathrm{M}$ BAP (SIM) or $0.4 \mu \mathrm{M}$ NAA (RIM) for 21 days. Different letters indicate significant differences at $P \leq 0,05$ (unpaired Student's t-test) ( $n=6$ Petri dishes each containing 15 cotyledons). 


\section{ANEXO B}

Table S1. List of relevant genes in the bin 3C. The genes shown are in-between the CAPs markers* TG130 (Solyc03g007180.1; 33 cM) and TG366 (Solyc03g063030.2; 54.8 cM)

\#

1

2

3

4

5

6

7

8

9

10

11

12

13
SGN ID

Solyc03g007210.2

Solyc03g007220

Solyc03g007310

Solyc03g007330

Solyc03g007460

SICRF4

Solyc03g007520

Solyc03g007730

Solyc03g007750

Solyc03g007760

Solyc03g007830

Solyc03g007910

Solyc03g007960.2

white flower

(wf)

Solyc03g019800
SGN anotation

Receptor serine/threonine kinase (AHRD V1 ${ }^{* * * *}$ O49202_ORYSJ); contains Interpro domain(s)

Membrane receptor-like protein 1 (AHRD V1 ${ }^{*_{-}{ }^{*}-}$ B3TJG2_CAPAN)

Abscisic acid receptor PYL8 (AHRD V1 **_* PYL8_ARATH); contains Interpro domain(s) IPR019587 Polyketide cyclase/dehydrase

Cell division protease $\mathrm{ftsH}$ homolog (AHRD V1 *-*FTSH_RICTY); contains Interpro domain(s) IPR005936

Peptidase M41, FtsH

Solanum lycopersicum Cytokinin Response Factor 4 (SICRF4); Member of the APETALA2/Ethylene Response Factor (AP2/ERF) family of transcription factors, ERF subfamily, clade VI or B-5 or CRF (Cytokinin Response Factor). Contains both an AP2/ERF-DNA binding domain and a CRF domain

Proline-rich cell wall protein-like (AHRD V1 ${ }^{* * *}$ Q8LG11_ARATH); contains Interpro domain(s) IPR015940 Ubiquitin-associated/translation elongation factor EF1B, Nterminal, eukaryote

Beta-ocimene synthase (AHRD V1 ${ }^{* * * *}$ B1P189_PHALU); contains Interpro domain(s) IPR005630 Terpene synthase, metal-binding domain

F-box family protein (AHRD V1 ${ }^{* * *}$ - D7MS95_ARALY); contains Interpro domain(s) IPR001810 Cyclin-like F-box

Cell division protease ftsH (AHRD V1 *--- FTSH_SHIFL); contains Interpro domain(s) IPR003959 ATPase, AAA-type, core

Threonine endopeptidase (AHRD V1 *--- B6TCN7_MAIZE)

Receptor-like serine/threonine kinase (AHRD V1 ${ }^{* * * *}$

C6FF81_SOYBN); contains Interpro domain(s) IPR002290

Serine/threonine protein kinase

beta-carotene hydroxylase 2

(CrtR-b2)

Myb-like protein B (AHRD V1 *_*- MYBB_DICDI); contains Interpro domain(s) IPR017877 MYB-like 
14

Solyc03g019900

Solyc03g019970

Solyc03g025170.1 gras10

17

18

19

20

21

22

23

24

25

26

Solyc03g031840

27

28

Solyc03g025360

Solyc03g025490

Solyc03g025870

Solyc03g026010

$\underline{\text { Solyc03g026070.2 }}$

Solyc03g031860.2 yellow flesh ( $r$ )
Serine/threonine-protein phosphatase (AHRD V1 ${ }^{* * * *}$ C6TK28_SOYBN); contains Interpro domain(s) IPR006186 Serine/threonine-specific protein phosphatase and bis(5nucleosyl)-tetraphosphatase

F-box protein interaction domain containing protein (AHRD V1 ***-Q60D10_SOLDE); contains Interpro domain(s) IPR017451 F-box associated type 1

GRAS family transcription factor (AHRD V1 **-* B9H3H7_POPTR); contains Interpro domain(s)

Protein serine/threonine kinase (AHRD V1 *_** D3BP85_POLPA); contains Interpro domain(s) IPR002290 Serine/threonine protein kinase

Gibberellin 20-oxidase-like protein (AHRD V1 ${ }^{* * * *}$ Q9FGV8_ARATH); contains Interpro domain(s) IPR005123 Oxoglutarate and iron-dependent oxygenase

MYB transcription factor (AHRD V1 **_* Q9LTJ5_ARATH); contains Interpro domain(s) IPR015495 Myb transcription factor

Solyc03g025920.2 F-box family protein (AHRD V1 ***-D7LS19_ARALY); contains Interpro domain(s) IPR001810 Cyclin-like F-box

F-box family protein (AHRD V1 ${ }^{* * *}$ - D7LS19_ARALY); contains Interpro domain(s) IPR001810 Cyclin-like F-box

F-box family protein (AHRD V1 ***- D7LS19_ARALY); contains Interpro domain(s) IPR001810 Cyclin-like F-box

Solyc03g025950.2 Membrane-associated progesterone receptor component 1 (AHRD V1 ${ }^{* * *}$ - CONU44_AJECG); contains Interpro domain(s) IPR001199 Cytochrome b5

Transmembrane protein 161B (AHRD V1 *-*-T161B_MOUSE)

Homeobox-leucine zipper protein ATHB-8 (AHRD V1 ***ATHB8_ARATH); contains Interpro domain(s) IPR002913 Lipidbinding START

Expa3 is one of the expansins involved in cell wall modification during cell expansion or differentiation in plants. In tomato, it is expressed in fruits, leaves, stems and flowers. In tomato fruit, Expa3 is highly expressed during green fruit expansion and maturation and with progressive decline during fruit ripening.

Phytoene synthase 1 (PSY1)

Solyc03g031970.2 Auxin response factor 8-1 (AHRD V1 **** E0A8P3_SOLLC); contains Interpro domain(s) IPR010525 Auxin response factor 
F-box family protein (AHRD V1 *-*- B9H220_POPTR); contains Interpro domain(s) IPR001810 Cyclin-like F-box

Auxin-induced SAUR-like protein (AHRD V1 ${ }^{* * *}$ Q8S349_CAPAN); contains Interpro domain(s) IPR003676 Auxin responsive SAUR protein

Short internode related sequence 5 (AHRD V1 -*-D2KC76_BRARP); contains Interpro domain(s) IPR007818 Protein of unknown function DUF702 FTSH3_SYNY3); contains Interpro domain(s) IPR003959 ATPase, AAA-type, core

MADS-box transcription factor 31 (AHRD V1 *_** B6TW19_MAIZE); contains Interpro domain(s) IPR002100 Transcription factor, MADS-box

MADS-box protein-like (AHRD V1 *-*- Q6YTZ9_ORYSJ); contains Interpro domain(s) IPR002100 Transcription factor, MADS-box

MADS-box protein (AHRD V1 *_*- D7MTU5_ARALY); contains Interpro domain(s) IPR002100 Transcription factor, MADS-box Interpro domain(s) IPR002100 Transcription factor, MADS-box contains Interpro domain(s) IPR000007 Tubby, $\bar{C}$-terminal

Homeobox-leucine zipper protein ATHB-40 (AHRD V1 ***D7MBE6_ARALY); contains Interpro domain(s) IPR001356 Homeobox

Homeobox-leucine zipper protein ATHB-40 (AHRD V1 ${ }^{* \star *}$ D7MBE6_ARALY); contains Interpro domain(s) IPR001356 Homeobox Homeobox 
B7E8X8_ORYSJ); contains Interpro domain(s) IPR001356 Homeobox

$44 \quad$ Solyc03g059070

Pto-like serine/threonine kinase (AHRD V1 ${ }^{* * * *}$ Q6W0C9_CAPCH); contains Interpro domain(s) IPR002290 Serine/threonine protein kinase

$45 \quad$ Solyc03g059200

MYB transcription factor (AHRD V1 ** -- Q9LSI7_ARATH); contains Interpro domain(s) IPR015495 Myb transcription factor Serine/threonine kinase (AHRD V1 ${ }^{*}{ }^{* *}$ C4QNN2_SCHMA); contains Interpro domain(s) IPR002290 Serine/threonine protein kinase

$47 \quad$ Solyc03g059300

NAC domain class transcription factor (AHRD V1 ${ }^{* * * *}$ D9ZJA8_MALDO); contains Interpro domain(s) IPR003441 No apical meristem (NAM) protein

$48 \quad$ Solyc03g059460

Serine/threonine-protein phosphatase 7 long form homolog (AHRD V1 **-- PPP7L_ARATH); contains Interpro domain(s) IPR019557 Aminotransferase-like, plant mobile domain

$49 \quad$ Solyc03g061600

Cell division cycle protein 27/anaphase promoting complex subunit 3 (AHRD V1 *--- A8NH71_COPC7); contains Interpro domain(s) IPR011990 Tetratricopeptide-like helical

$50 \quad$ Solyc03g061650

F-box/LRR-repeat protein At3g26922 (AHRD V1 *-*FBL47_ARATH); contains Interpro domain(s) IPR006566 FBDlike

$51 \quad$ Solyc03g062750

NAC domain protein IPR003441 (AHRD V1 ${ }^{* * *}$ B9IDF8_POPTR); contains Interpro domain(s) IPR003441 No apical meristem (NAM) protein

$52 \quad$ Solyc03g062800

F-box family protein (AHRD V1 ***-D7LS19_ARALY)

$53 \quad$ Solyc03g062810

F-box family protein (AHRD V1 ***-D7LS19_ARALY)

$54 \quad$ Solyc03g062820

MADS-box transcription factor 15 (AHRD V1 *-*-

D3U2H5_ORYSA); contains Interpro domain(s) IPR002100 Transcription factor, MADS-box

*The markers were defined previously in the Tomato-EXPEN 2000 from the Sol Genomics Network SGN (http://solgenomics.net/search/markers )

Table S2. List of relevant genes in the bin 6A. The genes shown are in-between the CAPs markers* CT216 ( Solyc06g005650.2.1; 0 cM) and TG590 (Solyc06g051360.2.1; 22cM)

\# $\quad$ SGN ID

$1 \quad \underline{\text { Solyc06g005800.2 }}$
SGN anotation

Serine/threonine-protein phosphatase (AHRD V1 ${ }^{* * * *}$ Q9SPE2_MALDO); contains Interpro domain(s) IPR006186 
2

3

4

5

6

7

8

9

10

11

12

13

14

15

Solyc06g007970

16

Solyc06g005950

Solyc06g006030

Solyc06g006050

Solyc06g006060

Solyc06g006070

Solyc06g007260

Solyc06g007270

Solyc06g007680

Solyc06g007830

Solyc06g007840

Solyc06g007890

Solyc06g007910

Solyc06g007920

Gibberellin-regulated family protein (AHRD V1 ${ }^{* *}$-D7LC91_ARALY); contains Interpro domain(s) IPR003854 Gibberellin regulated protein

Male sterility 5 family protein (Fragment) (AHRD V1 *--B1Q393_BRAOT); contains Interpro domain(s) IPR011990 Tetratricopeptide-like helical

Gibberellin regulated protein (AHRD V1 ** Q2HRH3_MEDTR); contains Interpro domain(s) IPR003854 Gibberellin regulated protein

Receptor protein kinase (AHRD V1 ${ }^{* * *}$ - Q6UJY9_TRITU); contains Interpro domain(s) IPR002290 Serine/threonine protein kinase

Fertility restorer (AHRD V1 ${ }^{* * *}$ - Q8L8A4_PETHY); contains Interpro domain(s) IPR002885 Pentatricopeptide repeat

Fertility restorer (AHRD V1 ***- Q8L8A4_PETHY); contains Interpro domain(s) IPR002885 Pentatricopeptide repeat

F-box/LRR-repeat protein 14 (AHRD V1 ${ }^{* * *}$ - B5X325_SALSA); contains Interpro domain(s) IPR006553 Leucine-rich repeat, cysteine-containing subtype
Auxin signaling F-box 1 (Fragment) (AHRD V1 ${ }^{* *}--$ D3K013_ARATH)
Auxin signaling F-box 2 (Fragment) (AHRD V1 ${ }^{* *}-$ D3K019_ARATH)
Q2HRH3_MEDTR); contains Interpro domain(s) IPR003854 Gibberellin regulated protein

Cell division protease FtsH homolog (AHRD V1 *-*- $^{*}$
6RIJ8_9PROT); contains Interpro domain(s) IPR005936 Peptidase M41, FtsH

LRR receptor-like serine/threonine-protein kinase FEI 1 (AHRD V1 ${ }^{* * * *}$ FEl1_ARATH); contains Interpro domain(s) IPR002290 Serine/threonine protein kinase

LRR receptor-like serine/threonine-protein kinase FEI 1 (AHRD V1 ${ }^{* * *}$ FEI1_ARATH) 
region, SHAQKYF class

$17 \quad$ Solyc06g008310

Elongator complex protein 2 (AHRD V1 **-- B0X467_CULQU); contains Interpro domain(s) IPR020472 G-protein beta WD-40 repeat, region

$18 \quad$ Solyc06g008320

Serine/threonine kinase (AHRD V1 ${ }^{* * * *}$ D8UCQ6_VOLCA); contains Interpro domain(s) IPR002290 Serine/threonine protein kinase

Serine/threonine-protein kinase 38 (AHRD V1 ${ }^{* * *}$ B6U4A0_MAIZE); contains Interpro domain(s) IPR002290 Serine/threonine protein kinase

Serine/threonine-protein kinase 19 (AHRD V1 *** B6TW02_MAIZE); contains Interpro domain(s) IPR018865 Serine-threonine protein kinase 19

NAC domain protein IPR003441 (AHRD V1 ${ }^{* * *}$ B9GRP6_POPTR); contains Interpro domain(s) IPR003441 No apical meristem (NAM) protein D3K014_ARATH) contains Interpro domain(s) IPR003311 AUX/IAA protein

Auxin responsive protein (AHRD V1 ${ }^{* * *}$ - D9IQE6_CATRO); contains Interpro domain(s) IPR003311 AUX/IAA protein

Solyc06g008810

Auxin F-box protein 5 (AHRD V1 **-- D7MPH1_ARALY); contains Interpro domain(s) IPR006553 Leucine-rich repeat, cysteine-containing subtype

Auxin F-box protein 5 (AHRD V1 **-- D7MPH1_ARALY); contains Interpro domain(s) IPR006553 Leucine-rich repeat, cysteine-containing subtype

Elongation factor Tu (AHRD V1 **** B9SFP0_RICCO); contains Interpro domain(s) IPR004541 Translation elongation factor EFTu/EF1A, bacterial and organelle Late embryogenesis abundant protein 3 Glycosyl hydrolase, family 13 , subfamily, catalytic region

F-box/LRR-repeat protein At3g48880 (AHRD V1 *-* FBL53_ARATH)
MYB transcription factor (AHRD V1 *_** Q94CJ3_ARATH); contains Interpro domain(s) IPR015495 Myb transcription factor 
32

33

34

35

36

37

38

39

40

41

42

43

44

45

46

47
Solyc06g030490

Solyc06g009430

Solyc06g009480

Solyc06g009540

Solyc06g009610

Solyc06g009710

Solyc06g009970

Solyc06g010250

Solyc06g011280

Solyc06g017860

Solyc06g017940

Solyc06g019190

Solyc06g024310

Solyc06g030470

Solyc06g030490

Solyc06g030600

Solyc06g030620
MYB transcription factor (AHRD V1 ${ }^{\text {_*}^{* *}}$ Q94CJ3_ARATH);

contains Interpro domain(s) IPR015495 Myb transcription factor

MYB transcription factor (AHRD V1 ${ }^{*}{ }^{* *}$ Q94CJ3_ARATH); contains Interpro domain(s) IPR015495 Myb transcription factor

Receptor-like kinase (AHRD V1 ${ }^{* \star * *}$ C6ZRN8_SOYBN); contains Interpro domain(s) IPR002290 Serine/threonine protein kinase

GRAS transcription factor (Fragment) (AHRD V1 *--A2Q2Y2_MEDTR); contains Interpro domain(s) IPR005202 GRAS transcription factor

Myb 12 transcription factor (AHRD V1 ${ }^{{ }^{*}}{ }^{* *}$ D2EBC3_9SOLN); contains Interpro domain(s) IPR015495 Myb transcription factor

Elongation factor 1-alpha (AHRD V1 ${ }^{* * *}$ - Q8H9C0_SOLTU); contains Interpro domain(s) IPR004539 Translation elongation factor EF1A, eukaryotic and archaeal IPR000795 Protein synthesis factor, GTP-binding

Nitrate transporter (AHRD V1 ${ }^{* \star * *}$ A5JUX2_9ROSI); contains Interpro domain(s) IPR016196 Major facilitator superfamily, general substrate transporter

Elongation factor 1-gamma (AHRD V1 ${ }^{* * *}$ - B7SDI2_ORYSJ); contains Interpro domain(s) IPR001662 Translation elongation factor EF1B, gamma chain, conserved

Serine carboxypeptidase (AHRD V1 ${ }^{* * *}$ Q2Z1Y2_PRUMU); contains Interpro domain(s) IPR001563 Peptidase S10, serine carboxypeptidase

Homeobox-leucine zipper protein HDG7 (AHRD V1 ***HDG7_ARATH)

Serine/threonine-protein phosphatase 7 long form homolog (AHRD V1 ***-PPP7L_ARATH)

Abscisic acid insensitive 8 homologue (AHRD V1 ${ }^{*{ }_{-}-}$ A5A6Q2_WHEAT)

Auxin-regulated protein (AHRD V1 ${ }^{* * *}$ - Q945F5_SOLLC); contains Interpro domain(s) IPR010369 Protein of unknown function DUF966

Serine/threonine-protein phosphatase (AHRD V1 ${ }^{* * * *}$ D7LDT2_ARALY); contains Interpro domain(s) IPR006186 Serine/threonine-specific protein phosphatase and bis(5nucleosyl)-tetraphosphatase

F-box/LRR-repeat protein 4 (AHRD V1 ***-FBL4_ARATH)

F-box/LRR-repeat protein (AHRD V1 ${ }^{*-*}$ - C0S347_PARBP) 
48

49

50

51

52

53

54

55

56

57

58

59

60

61

62

63
Solyc06g033830

Solyc06g033870

Solyc06g034000

Solyc06g034030

Solyc06g034130

Solyc06g034260

Solyc06g034340

Solyc06g035480

Solyc06g035530.2

Solyc06g035570

Solyc06g035630

Solyc06g035700

Solyc06g035880

Solyc06g036080

Solyc06g036090

Solyc06g036170
MADS-box transcription factor 1 (AHRD V1 ${ }^{*_{-}{ }_{-}}$

D1MFS6_HEVBR); contains Interpro domain(s) IPR002100

Transcription factor, MADS-box

Myb-related transcription factor (AHRD V1 ****

B5RHV2_MUSBA); contains Interpro domain(s) IPR015495 Myb transcription factor

Myb-related transcription factor-like protein (AHRD V1 **_* Q9SPG6_ARATH); contains Interpro domain(s) IPR015495 Myb transcription factor

Myb family transcription factor (AHRD V1 ***Q2A9N2_BRAOL); contains Interpro domain(s) IPR006447 Myb-like DNA-binding region, SHAQKYF class

Root cap protein 3 (Fragment) (AHRD V1 ${ }^{* *}{ }_{--}$ Q1HVA8_MESVI); contains Interpro domain(s) IPR009646 Root cap

F-box protein At2g35280 (AHRD V1 *-*-FB127_ARATH)

NAC domain protein IPR003441 (AHRD V1 ${ }^{* * *}$ B9ICS8_POPTR); contains Interpro domain(s) IPR003441 No apical meristem (NAM) protein

Serine/threonine-protein phosphatase 7 long form homolog (AHRD V1 *--- PPP7L_ARATH); contains Interpro domain(s) IPR019557 Aminotransferase-like, plant mobile domain

Gibberellin 20-oxidase-2 (AHRD V1 **** Q9ZPP3_SOLLC); contains Interpro domain(s) IPR005123 Oxoglutarate and irondependent oxygenase

Transcription factor MADS-box (AHRD V1 *** A2Q6H2_MEDTR); contains Interpro domain(s) IPR002100

Transcription factor, MADS-box

GRAS family transcription factor (AHRD V1 **-B917E1_POPTR)

Ethylene-responsive transcription factor 1 (AHRD V1 *** * ERF1_ORYSJ); contains Interpro domain(s) IPR001471

Pathogenesis-related transcriptional factor and ERF, DNAbinding

Homeobox-leucine zipper protein ROC7 (AHRD V1 ***ROC7_ORYSJ)

Protein serine/threonine kinase (AHRD V1 ${ }^{*_{-} * *}$ D3BP85_POLPA); contains Interpro domain(s) IPR002290 Serine/threonine protein kinase

F-box-containing protein 1 (AHRD V1 ***-B2LUQ9_MALDO)

Scarecrow-like 1 transcription factor (Fragment) (AHRD V1 *--* 
gras9

64

65

66

67

68

69

70

71

72

73

74

75

76

77

78
Solyc06g036260.2

Solyc06g036300

Solyc06g036320

Solyc06g036450

Solyc06g043100

Solyc06g048380

Solyc06g048590

Solyc06g048710

Solyc06g048840

Solyc06g049050.2

Solyc06g050110

Solyc06g050390

Solyc06g050500

$\underline{\text { Solyc06g050520.1 }}$

Solyc06g050650
B1PPU0_PINPS); contains Interpro domain(s) IPR005202 GRAS transcription factor

Beta-carotene hydroxylase 1

MYB transcription factor (Fragment) (AHRD V1 ${ }^{* *}-*$

A1DR87_CATRO); contains Interpro domain(s) IPR006447

Myb-like DNA-binding region, SHAQKYF class

Serine/threonine-protein phosphatase 7 long form homolog

(AHRD V1 **-- PPP7L_ARATH); contains Interpro domain(s)

IPR019557 Aminotransferase-like, plant mobile domain

Ethylene receptor (AHRD V1 ${ }^{* * *}$ - COILN8_COFCA)

Serine/threonine-protein phosphatase 7 long form homolog (AHRD V1 **-- PPP7L_ARATH); contains Interpro domain(s)

IPR019557 Aminotransferase-like, plant mobile domain

MADS-box transcription factor 1 (AHRD V1 *-*-

D1MFS6_HEVBR); contains Interpro domain(s) IPR002100 Transcription factor, MADS-box

Transmembrane protein (AHRD V1 **-- CONFK1_AJECG); contains Interpro domain(s) IPR009637 Transmembrane receptor, eukaryota

Auxin-responsive GH3-like (AHRD V1 ${ }^{* * *}$ - Q0GUM1_ARATH); contains Interpro domain(s) IPR004993 GH3 auxin-responsive promoter

Late embryogenesis abundant protein (AHRD V1 *** A4VBF1_9FABA); contains Interpro domain(s) IPR000389 Small hydrophilic plant seed protein

Expansin (AHRD V1 ${ }^{* * *}$ - O82625_SOLLC); contains Interpro domain(s) IPR007112 Expansin 45, endoglucanase-like

IPR007117 Pollen allergen/expansin, C-terminal

Gibberellin 20-oxidase (AHRD V1 ${ }^{* * *}$ Q9M4A0_SOLDU); contains Interpro domain(s) IPR005123 Oxoglutarate and irondependent oxygenase

Serine/threonine-protein phosphatase 7 long form homolog (AHRD V1 *-*- PPP7L_ARATH); contains Interpro domain(s) IPR019557 Aminotransferase-like, plant mobile domain

Abscisic acid receptor PYL4 (AHRD V1 *--- PYL4_ARATH); contains Interpro domain(s) IPR019587 Polyketide cyclase/dehydrase

Ethylene-responsive transcription factor 1 (AHRD V1 *-*ERF1_ORYSJ); contains Interpro domain(s) IPR001471 Pathogenesis-related transcriptional factor and ERF, DNAbinding

Serine/threonine-protein phosphatase 7 long form homolog 
(AHRD V1 *--- PPP7L_ARATH); contains Interpro domain(s) IPR019557 Aminotransferase-like, plant mobile domain

$79 \quad$ Solyc06g051060

Myb family transcription factor-like (AHRD V1 *--Q6ER41_ORYSJ); contains Interpro domain(s) IPR006447

Myb-like DNA-binding region, SHAQKYF class

*The markers were defined previously in the Tomato-EXPEN 2000 from the Sol Genomics Network SGN (http://solgenomics.net/search/markers ) 
Table S3. List of relevant genes in the bin $7 \mathrm{H}$. The genes shown are in;between the CAPs markers* TG438 (Solyc07g064080.2.1; 73cM) and TG499 (Solyc07g066630.1.1; 97cM)

\#

1

2

3

4

5

6

7

8

9

10

11

12

13

14
SGN ID Solyc07g064090

Solyc07g064260

Solyc07g064340

Solyc07g064380

Solyc07g064400

Solyc07g064470

Solyc07g064670.2

Solyc07g064820

Solyc07g064900

Solyc07g065020

Solyc07g065050

Solyc07g065130

Solyc07g065140

Solyc07g065270.1

GRAS7
SGN anotation

Fertilization-independent endosperm protein

F-box family protein (AHRD V1 *-*-D7LTH7_ARALY); contains Interpro domain(s) IPR013101 Leucine-rich repeat 2

Serine/threonine-protein kinase (AHRD V1 ${ }^{* * * *}$ C6ZRV0_SOYBN); contains Interpro domain(s) IPR002290 Serine/threonine protein kinase

Serine/threonine-protein phosphatase 7 long form homolog (AHRD V1 *--- PPP7L_ARATH); contains Interpro domain(s) IPR019557 Aminotransferase-like, plant mobile domain

Serine/threonine-protein phosphatase 7 long form homolog (AHRD V1 *-*- PPP7L_ARATH); contains Interpro domain(s) IPR019557 Aminotransferase-like, plant mobile domain

Transmembrane protein 14C (AHRD V1 ${ }^{* * *}$ - C3KI83_ANOFI); contains Interpro domain(s) IPR005349 Uncharacterised protein family UPF0136, Transmembrane

Beta-1 3-galactosyltransferase 6 (AHRD V1 **** B6UBH3_MAIZE); contains Interpro domain(s) IPR002659 Glycosyl transferase, family 31

Protein serine/threonine kinase (AHRD V1 ${ }^{* * *}$ D3BP85_POLPA); contains Interpro domain(s) IPR002290 Serine/threonine protein kinase

Extracellular ligand-gated ion channel (AHRD V1 ${ }^{* * *}$ D7LAY2_ARALY)

Serine/threonine-protein phosphatase (AHRD V1 ${ }^{* * * *}$ B9I197_POPTR); contains Interpro domain(s) IPR006186 Serine/threonine-specific protein phosphatase and bis(5nucleosyl)-tetraphosphatase

Cell division protein ftsZ (AHRD V1 ${ }^{* * *}$ - B6TH29_MAIZE); contains Interpro domain(s) IPR000158 Cell division protein

FtsZ, N-terminal

Calcium-binding protein 39 (AHRD V1 **** B6U5L1_MAIZE); contains Interpro domain(s) IPR013878 Mo25-like

Beta-1 2-xylosyltransferase (AHRD V1 **** Q2UVB5_SOLTU)

GRAS family transcription factor (AHRD V1 **_* B9IAQ7_POPTR); contains Interpro domain(s) IPR005202 GRAS transcription factor 
15

Solyc07g065340

Solyc07g065660

Solyc07g066150

18

Solyc07g066240

19

Solyc07g066250.1 lateral suppresser (Is)

20

Solyc07g066310

21

22

$$
\text { flacca (flc) }
$$

Serine acetyltransferase (AHRD V1 ${ }^{* * *}$ Q39533_CITLA); contains Interpro domain(s) IPR005881 Serine Oacetyltransferase

Cellulose synthase (AHRD V1 ${ }^{* * * *}$ Q2HT17_MEDTR); contains Interpro domain(s) IPR005150 Cellulose synthase

Photosystem I reaction center subunit $\mathrm{V}\left(\mathrm{AHRD} \mathrm{V} 1^{* * *}\right.$ B6U534_MAIZE); contains Interpro domain(s) IPR017494 Photosystem I reaction center, PsaG, plant

F-box/LRR-repeat protein 14 (AHRD V1 * **- B5X1Y2_SALSA); contains Interpro domain(s) IPR001810 Cyclin-like F-box

GRAS family transcription factor (Fragment) (AHRD V1 **_* B1Q3B1_BRACM); contains Interpro domain(s) IPR005202 GRAS transcription factor

Photosystem II polypeptide (AHRD V1 ${ }^{\text {*** }}$-Q6V7X5_TRIPR); contains Interpro domain(s) IPR006814 Photosystem II protein PsbR

molybdenum cofactor sulfurase This gene sulfurates the molybdenum cofactor, a necessary step for the action of xanthine dehydrogenase and aldehyde oxidases which are sulfated molybenum requiring enzymes.

Auxin responsive SAUR protein (AHRD V1 **-

Q1SN26_MEDTR); contains Interpro domain(s) IPR003676

Auxin responsive SAUR protein

*The markers were defined previously in the Tomato-EXPEN 2000 from the Sol Genomics Network SGN (http://solgenomics.net/search/markers ) 
Table S4. List of relevant genes in the bin 8F. The genes shown are in-between the CAPs markers* TG510 (Solyc08g078380.1; 57cM) and CT148 (Solyc08g079830.1.1; 67cM)

\#

1

2

3

4

5

6

7

8

9

10

11

12

13
SGN ID Solyc08g078410

Solyc08g078420

Solyc08g078460

Solyc08g078640

Solyc08g078750

Solyc08g078800

Solyc08g078850

NIT1

Solyc08g078900

Solyc08g078910

Solyc08g078920

Solyc08g078930

Solyc08g078940

Solyc08g078950.2
SGN anotation

Ethylene-responsive transcription factor 1 (AHRD V1 ${ }^{*}$ *ERF1_ORYSJ); contains Interpro domain(s) IPR001471 Pathogenesis-related transcriptional factor and ERF, DNAbinding

Ethylene-responsive transcription factor 1 (AHRD V1 *-*ERF1_ORYSJ); contains Interpro domain(s) IPR001471

Pathogenesis-related transcriptional factor and ERF, DNAbinding

Inositol 2-dehydrogenase like protein (AHRD V1 ** O23580_ARATH); contains Interpro domain(s) IPR016040 $\mathrm{NAD}(\mathrm{P})$-binding domain

Pectinesterase (AHRD V1 ${ }^{* * * *}$ D7MP41_ARALY); contains Interpro domain(s) IPR000070 Pectinesterase, catalytic DEAD-box ATP-dependent RNA helicase 41 (AHRD V1 *-* RH41_ORYSJ); contains Interpro domain(s) IPR007529 Zinc finger, HIT-type

GRAS family transcription factor (AHRD V1 **_* B9GVG4_POPTR); contains Interpro domain(s) IPR005202 GRAS transcription factor

Nitrate transporter (AHRD V1 ${ }^{* * * *}$ Q852P7_TOBAC); contains Interpro domain(s) IPR000109 TGF-beta receptor, type I/II extracellular region

Cortical cell-delineating protein (AHRD V1 *---

B6U436_MAIZE); contains Interpro domain(s) IPR013770 Plant lipid transfer protein and hydrophobic protein, helical

Cortical cell-delineating protein (AHRD V1 **--

B6U436_MAIZE); contains Interpro domain(s) IPR013770 Plant lipid transfer protein and hydrophobic protein, helical

Proline-rich protein (AHRD V1 **-- Q41125_PHAVU); contains Interpro domain(s) IPR013770 Plant lipid transfer protein and hydrophobic protein, helical

Cortical cell-delineating protein (AHRD V1 ${ }^{* *}$

B6T026_MAIZE); contains Interpro domain(s) IPR013770 Plant lipid transfer protein and hydrophobic protein, helical

Cortical cell-delineating protein (AHRD V1 **--

B6U436 MAIZE); contains Interpro domain(s) IPR013770 Plant lipid transfer protein and hydrophobic protein, helical

Nitrate transporter (AHRD V1 ${ }^{* * * *}$ Q852P7_TOBAC); contains Interpro domain(s) IPR000109 TGF-beta receptor, type I/II extracellular region 
14

15

16

17

18

19

20

21

22

23

24

25

26

27

28
Solyc08g079080

Ling

Solyc08g079120

Solyc08g079130

Solyc08g079140

Solyc08g079150

Solyc08g079160

Solyc08g079170

Solyc08g079180

Solyc08g079190

Solyc08g079200

Solyc08g079230

Solyc08g079250

Solyc08g079260

Solyc08g079270

Solyc08g079280.2
Acid beta-fructofuranosidase (AHRD V1 ${ }^{* *}$-- Q575T1_WHEAT); contains Interpro domain(s) IPR001362 Glycoside hydrolase, family 32

NAC domain protein IPR003441 (AHRD V1 ${ }^{* * *}$ B9N3P6_POPTR); contains Interpro domain(s) IPR003441 No apical meristem (NAM) protein

Auxin-responsive family protein (AHRD $\mathrm{V} 1^{* * *}$ D7ME23_ARALY); contains Interpro domain(s) IPR003676 Auxin responsive SAUR protein

Auxin-induced SAUR-like protein (AHRD V1 *-*Q8S351_CAPAN); contains Interpro domain(s) IPR003676 Auxin responsive SAUR protein

Auxin responsive SAUR protein (AHRD V1 *-*Q1SN26_MEDTR); contains Interpro domain(s) IPR003676 Auxin responsive SAUR protein

Vacuolar-processing enzyme (AHRD V1 **-- B9RBP3_RICCO); contains Interpro domain(s) IPR001096 Peptidase C13, legumain

Stress-induced protein sti1-like protein (AHRD V1 ${ }^{* *}$ Q9STH1_ARATH); contains Interpro domain(s) IPR011990 Tetratricopeptide-like helical

Elongation factor G (AHRD V1 ***-Q9SI75_ARATH); contains Interpro domain(s) IPR004540 Translation elongation factor EFG/EF2

Cortical cell-delineating protein (AHRD V1 *---

B6T836_MAIZE); contains Interpro domain(s) IPR013770 Plant lipid transfer protein and hydrophobic protein, helical

Cortical cell-delineating protein (AHRD V1 ${ }^{* *}{ }_{--}$

B6U3L7_MAIZE); contains Interpro domain(s) IPR013770 Plant lipid transfer protein and hydrophobic protein, helical

Cortical cell-delineating protein (AHRD V1 *---

B6T836_MAIZE); contains Interpro domain(s) IPR013770 Plant lipid transfer protein and hydrophobic protein, helical

Lipid transfer protein (AHRD V1 *_** O22110_PICAB); contains Interpro domain(s) IPR003612 Plant lipid transfer protein/seed storage/trypsin-alpha amylase inhibitor

Serine/threonine-protein phosphatase (Fragment) (AHRD V1 *-- Q4RFT2_TETNG); contains Interpro domain(s) IPR011990 Tetratricopeptide-like helical

MYB transcription factor (AHRD V1 ***- Q6R075_ARATH); contains Interpro domain(s) IPR015495 Myb transcription factor 
29 Solyc08g079300 Cytochrome P450 (AHRD V1 ${ }^{* * *}$ - B9MZK4_POPTR); contains Interpro domain(s) IPR002401 Cytochrome P450, E-class, group I

30

Solyc08g079310.2

Cytochrome P450

$31 \quad \underline{\text { Solyc08g079330.1 }}$

Cytochrome P450

32

Solyc08g079350.1

Cytochrome p450

33

Solyc08g079370.1

Cytochrome P450

\begin{abstract}
${ }^{*}$ The markers were defined previously in the Tomato-EXPEN 2000 from the Sol Genomics Network -
\end{abstract} SGN (http://solgenomics.net/search/markers ) 
Table S5. List of relevant genes in the bin 9DE. The genes shown are in-between the CAPs markers* TG223A (Solyc09g009370.2.1; 32cM) and TG568 (Solyc09g047900.1.1; 50.1 cM)

\begin{tabular}{|c|c|c|}
\hline \# & SGN ID & SGN anotation \\
\hline 1 & Solyc09g009430 & $\begin{array}{c}\text { Cell division protein ftsZ (AHRD V1 }{ }^{* * *} \text { - BOBYG5_ACAM1); } \\
\text { contains Interpro domain(s) IPR000158 Cell division protein } \\
\text { FtsZ, N-terminal }\end{array}$ \\
\hline 2 & Solyc09g009470 & $\begin{array}{c}\text { F-box family protein (AHRD V1 }{ }^{* * *} \text { - D7KV05_ARALY); contains } \\
\text { Interpro domain(s) IPR001810 Cyclin-like F-box }\end{array}$ \\
\hline 3 & Solyc09g009480 & S-locus F-box-like protein b (AHRD V1 ${ }^{* * *}$ - B0F0G1_PETIN) \\
\hline 4 & Solyc09g009560.1 & SELF PRUNING 9D \\
\hline 5 & Solyc09g009750 & $\begin{array}{l}\text { Subtilisin-like serine protease (AHRD V1 }{ }^{* *_{-}{ }^{*}} \\
\text { Q8L7D2_ARATH); contains Interpro domain(s) IPR015500 } \\
\text { Peptidase S8, subtilisin-related }\end{array}$ \\
\hline 6 & Solyc09g009760 & $\begin{array}{l}\text { Z-box binding factor } 2 \text { protein (AHRD V1 *-*-Q5K1L6_ARATH); } \\
\text { contains Interpro domain(s) IPR011616 bZIP transcription } \\
\text { factor, bZIP-1 }\end{array}$ \\
\hline 7 & Solyc09g009870 & $\begin{array}{l}\text { F-box protein family-like (AHRD V1 }{ }^{* * *} \text { - Q6ZLE2_ORYSJ); } \\
\text { contains Interpro domain(s) IPR001810 Cyclin-like F-box }\end{array}$ \\
\hline 8 & Solyc09g009920 & $\begin{array}{c}\text { F-box family protein (AHRD V1 }{ }^{* * *} \text { - D7MLR5_ARALY); contains } \\
\text { Interpro domain(s) IPR013596 FBD }\end{array}$ \\
\hline 9 & Solyc09g009980 & $\begin{array}{c}\text { Auxin-induced SAUR-like protein (AHRD V1 }{ }^{*} \text {--- } \\
\text { Q8S349_CAPAN); contains Interpro domain(s) IPR003676 } \\
\text { Auxin responsive SAUR protein }\end{array}$ \\
\hline
\end{tabular}

10

Solyc09g010080 Lin5

Solyc09g010090

Lin7
Invertase 7, an extracellular invertase, catalyses cleavage of sucrose in apoplast and its supply from source to sink organs in tomato. In tomato, Lin7 is specifically expressed in flower and flowerbud. Its expression is highest in stamen, much lower in gynoecia and very minute in petal.

NAC domain protein IPR003441 (AHRD V1 ${ }^{* * *}$ B9IIS2_POPTR); contains Interpro domain(s) IPR003441 No apical meristem (NAM) protein

TPR repeat-containing protein (AHRD $\mathrm{V} 1{ }^{* * *}$ B4D9Q4_9BACT); contains Interpro domain(s) IPR001440 Tetratricopeptide TPR-1 

(PHAN)

Solyc09g010850

$\underline{\text { Solyc09g010860.2 }}$

Solyc09g010920

Solyc09g010950

Solyc09g011320

Solyc09g011370

Solyc09g011680

Solyc09g011780

Solyc09g012010

Solyc09g012020

Solyc09g014250

Solyc09g014380 contains Interpro domain(s) IPR003340 Transcriptional factor B3

MYB transcription factor (AHRD V1 ${ }^{* * * *}$ Q6R032_ARATH); contains Interpro domain(s) IPR015495 Myb transcription factor

Solyc09g010840.1 Myb family transcription factor (AHRD V1 **_* D1LXI9_9ROSI); PHANTASTICA contains Interpro domain(s) IPR015495 Myb transcription factor

Auxin transporter-like protein 1 (AHRD V1 ****
B6U1Y3_MAIZE); contains Interpro domain(s) IPR013057 Amino acid transporter, transmembrane

Late embryogenesis abundant protein (AHRD V1 ${ }^{* * *}$ A4VBF1_9FABA); contains Interpro domain(s) IPR000389

Small hydrophilic plant seed protein

Myb family transcription factor (Fragment) (AHRD V1 **_* D7M1F0_ARALY); contains Interpro domain(s) IPR006447 Myb-like DNA-binding region, SHAQKYF class

Auxin transporter-like protein 1 (AHRD V1
B6U***
B 1Y_MAIZE); contains Interpro domain(s) IPR013057 ATP binding / serine-threonine kinase (AHRD V1 ${ }^{* * * *}$
C5DB71_VITVI); contains Interpro domain(s) IPR002290 Serine/threonine protein kinase

Expansin (AHRD V1 ${ }^{* * *}$ - Q9ZP32_SOLLC); contains Interpro domain(s) IPR007112 Expansin 45, endoglucanase-like

IPR007117 Pollen allergen/expansin, C-terminal

GRAS family transcription factor (AHRD V1 $1^{* *}-{ }^{*}$
B9HBM9_POPTR); contains Interpro domain(s) IPR005202 GRAS transcription factor

FTSH BACSU); contains Interpro domain(s) IPR005936 Peptidase M41, FtsH

Serine/threonine-protein kinase-like protein (AHRD V1 ${ }^{* * *}$ Q9M269_ARATH); contains Interpro domain(s) IPR002290 Serine/threonine protein kinase

F-box/LRR-repeat protein 14 (AHRD V1 ***- FBL14_ARATH); contains Interpro domain(s) IPR006553 Leucine-rich repeat, cysteine-containing subtype

\section{Ethylene receptor (AHRD V1 ${ }^{* * *}$ - D7RIC8_COFCA)}

MYB transcription factor (AHRD V1 ${ }^{* * *}$ Q6R080_ARATH); contains Interpro domain(s) IPR015495 Myb transcription factor

F-box family protein (AHRD V1 ***- B9HX54_POPTR); contains Interpro domain(s) IPR017451 F-box associated type 1

F-box family protein (AHRD V1 ***- D7L723_ARALY); contains Interpro domain(s) IPR017451 F-box associated type 1

Homeobox-leucine zipper protein ROC3 (AHRD V1 *-*ROC3_ORYSJ); contains Interpro domain(s) IPR001356 
Homeobox

31

32

33

34

35

36

37

38

39

40

41

42
Solyc09g015380

Solyc09g015390

Solyc09g015500

Solyc09g018020

Solyc09g018170

Solyc09g018410

$\underline{\text { Solyc09g018460.1 }}$ GRAS5

Solyc09g018920

Solyc09g030390

Solyc09g042210

Solyc09g042260
Solyc09g031570

Abscisic acid receptor PYL6 (AHRD V1 ${ }^{* *}$-- PYL6_ARATH); contains Interpro domain(s) IPR019587 Polyketide cyclase/dehydrase

Serine/threonine-protein phosphatase 7 long form homolog (AHRD V1 *-- PPP7L_ARATH); contains Interpro domain(s) IPR019557 Aminotransferase-like, plant mobile domain

F-box-like/WD repeat-containing protein TBL1X (AHRD V1 ***TBL1X_MACFA)

Expansin (AHRD V1 ${ }^{* * *}$ - A5H0F8_CARCN); contains Interpro domain(s) IPR002963 Expansin

Serine/threonine protein kinase (AHRD V1 *_* D0NNA3_PHYIN); contains Interpro domain(s) IPR002290 Serine/threonine protein kinase

Gibberellin 20-oxidase 1 (AHRD V1 ***-Q8RVP1_NICSY)

GRAS family transcription factor (Fragment) (AHRD V1 ${ }^{* *}$-B1Q3B1_BRACM); contains Interpro domain(s) IPR005202 GRAS transcription factor

Serine/threonine-protein phosphatase 7 long form homolog (AHRD V1 *--- PPP7L_ARATH); contains Interpro domain(s) IPR019557 Aminotransferase-like, plant mobile domain

Serine/arginine repetitive matrix 1 (Fragment) (AHRD V1 *--Q28CC2_XENTR); contains Interpro domain(s) IPR002483 Splicing factor PWI

Cellulose synthase A catalytic subunit 3 (AHRD V1 --* CESA3_ARATH)

Gibberellin 20-oxidase 1 (AHRD V1 ${ }^{* * *}$ - Q8RVP1_NICSY); contains Interpro domain(s) IPR005123 Oxoglutarate and irondependent oxygenase

ATP binding / serine-threonine kinase (AHRD V1 ${ }^{* * * *}$ C5DB71_VITVI); contains Interpro domain(s) IPR002290 Serine/threonine protein kinase

*The markers were defined previously in the Tomato-EXPEN 2000 from the Sol Genomics Network SGN (http://solgenomics.net/search/markers ) 
Table S6. List of relevant genes in the bin 10F. The genes shown are in-between the CAPs markers* CT57 (Solyc10g081620.1.1; 62cM) and CT95 (Solyc10g084600.1.1; 73cM)

\section{\#}

2

3

4

5

6

7

8

9

10

11

12

13

14
SGN ID

Solyc10g081650.1

tangerine ( $t$ )

Solyc10g082010

Solyc $10 \mathrm{~g} 082020$

Solyc10g083210

Solyc $10 \mathrm{~g} 083230$

Solyc10g083290

Lin6

Solyc $10 \mathrm{~g} 083300$

Lin8

Solyc $10 \mathrm{~g} 083320$

Solyc $10 \mathrm{~g} 083340$

Solyc10g083450

Solyc10g083480

Solyc $10 \mathrm{~g} 083490$

Solyc $10 \mathrm{~g} 083510$

Solyc10g083560
SGN anotation

Carotenoid isomerase, chloroplastic (CrtISO)

F-box protein (Fragment) (AHRD V1 *-*- B0Z665_9ROSA); contains Interpro domain(s) IPR006527 F-box associated

Cytokinin riboside 5\&apos;--monophosphate phosphoribohydrolase LOG (AHRD V1 **-- LOG_ORYSJ); contains Interpro domain(s) IPR005269 Conserved hypothetical protein CHP00730

Auxin response factor 1 (AHRD V1 *-*- D9HNS8_MAIZE); contains Interpro domain(s) IPR003340 Transcriptional factor B3

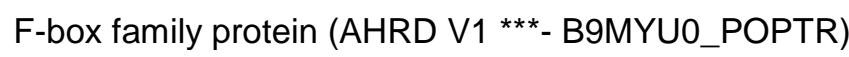

Invertase 6, an extracellular invertase, catalyses cleavage of sucrose in apoplast and its supply from source to sink organs in tomato. It is responsible for establishing sink metabolism in response to wounding and pathogen attack. Furthermore, its expression is induced by glucose and zeatin. Organs where

Lin6 is expressed include root, flowerbud and tumor.

Invertase 8 is cloned from genomic DNA and no mRNA has been detected in any tissue in tomato yet.

Auxin-induced SAUR-like protein (AHRD V1 *--Q8S349_CAPAN); contains Interpro domain(s) IPR003676 Auxin responsive SAUR protein

Myb family transcription factor-like (AHRD V1 *--Q6H510_ORYSJ); contains Interpro domain(s) IPR006447 Myb-like DNA-binding region, SHAQKYF class

NAC domain protein IPR003441 (AHRD V1 *-*B9HNX9_POPTR); contains Interpro domain(s) IPR003441 No apical meristem (NAM) protein

F-box family protein (AHRD V1 ${ }^{* * *}$ - D7KV05_ARALY); contains Interpro domain(s) IPR001810 Cyclin-like F-box

Cell division protein ftsZ (AHRD V1 ${ }^{* * *}$ - AOYTKO_LYNSP); contains Interpro domain(s) IPR000158 Cell division protein

FtsZ, N-terminal

Growth-regulating factor 2 (AHRD V1 **-- Q6AWY7_ORYSJ); contains Interpro domain(s) IPR014977 WRC

Ethylene-responsive transcription factor 1 (AHRD V1 *-*ERF1_ORYSJ); contains Interpro domain(s) IPR001471 
15

16

17

18

19

20

21

22

23

24
Solyc10g083920

Solyc10g084150

Solyc10g083670

Solyc10g083730

Solyc 10 g083900

Solyc 10 0084010

Solyc10g084020

Solyc10g084030

Solyc10g084260

Solyc10g084370
Pathogenesis-related transcriptional factor and ERF, DNAbinding

Cellulose synthase-like $\mathrm{C} 2$ glycosyltransferase family 2 (AHRD V1 **_* A9RNK0_PHYPA); contains Interpro domain(s) IPR001173 Glycosyl transferase, family 2

F-box protein PP2-B1 (AHRD V1 *_*- PP2B1_ARATH); contains Interpro domain(s) IPR001810 Cyclin-like F-box

MYB transcription factor (AHRD V1 *_*- Q56UT4_ORYSJ); contains Interpro domain(s) IPR015495 Myb transcription factor

Serine/threonine-protein phosphatase $2 \mathrm{~A} 56 \mathrm{kDa}$ regulatory subunit delta isoform (AHRD V1 ${ }^{* * *}$ - 2A5D_RABIT); contains Interpro domain(s) IPR002554 Protein phosphatase $2 A$, regulatory $B$ subunit, $B 56$

Auxin-responsive family protein (AHRD V1 *** D7L8D5_ARALY); contains Interpro domain(s) IPR003676 Auxin responsive SAUR protein

Auxin responsive SAUR protein (AHRD V1 *-*Q2HTF3_MEDTR); contains Interpro domain(s) IPR003676 Auxin responsive SAUR protein

Auxin responsive SAUR protein (AHRD V1 *-*Q1SN26_MEDTR); contains Interpro domain(s) IPR003676 Auxin responsive SAUR protein

Cytokinin riboside 5\&apos;-monophosphate phosphoribohydrolase LOG (AHRD V1 ${ }^{* *}{ }_{--}$LOG_ORYSJ); contains Interpro domain(s) IPR005269 Conserved hypothetical protein CHP00730

Cell number regulator 8 (AHRD V1 ${ }^{* *}$-- B4FUS3_MAIZE); contains Interpro domain(s) IPR006461 Protein of unknown function Cys-rich

MYB transcription factor (Fragment) (AHRD V1 ${ }^{* *}$-A1DR87_CATRO); contains Interpro domain(s) IPR006447 Myb-like DNA-binding region, SHAQKYF class

*The markers were defined previously in the Tomato-EXPEN 2000 from the Sol Genomics Network SGN (http://solgenomics.net/search/markers ) 